\title{
Romania: Second Review under the Stand-By Arrangement and Request for Modification of Performance Criteria-Staff Report; Staff Supplement; Press Release on the Executive Board Discussion; and Statement by the Executive Director for Romania.
}

In the context of the second review under the stand-by arrangement and request for modification of performance criteria, the following documents have been released and are included in this package:

- $\quad$ The staff report for the second review under the Stand-By Arrangement and request for Modification of Performance Criteria, prepared by a staff team of the IMF, following discussions that ended on August 1, 2011 with the officials of Romania on economic developments and policies. Based on information available at the time of these discussions, the staff report was completed on September 14, 2011. The views expressed in the staff report are those of the staff team and do not necessarily reflect the views of the Executive Board of the IMF.

- A staff supplement of September 23, 2011 updating information on recent developments.

- $\quad$ A Press Release summarizing the views of the Executive Board as expressed during its September 29, 2011 discussion of the staff report that completed the request and/or review.

- $\quad$ A statement by the Executive Director for Romania.

The document listed below has been or will be separately released.

Letter of Intent and TMU sent to the IMF by the authorities of Romania*

*Also included in Staff Report

The policy of publication of staff reports and other documents allows for the deletion of market-sensitive information.

Copies of this report are available to the public from

International Monetary Fund • Publication Services

$70019^{\text {th }}$ Street, N.W. • Washington, D.C. 20431

Telephone: (202) 623-7430 • Telefax: (202) 623-7201

E-mail: publications@imf.org Internet: http://www.imf.org

\section{International Monetary Fund Washington, D.C.}


INTERNATIONAL MONETARY FUND

ROMANIA

\title{
Second Review Under the Stand-By Arrangement and Request for Modification of Performance Criteria
}

\author{
Prepared by the European Department \\ (In Consultation with Other Departments)
}

Approved by Anne-Marie Gulde and Aasim Husain

September 14, 2011

\begin{abstract}
Stand-By Arrangement (SBA) and follow-up SBA: A 24-month, SDR 3,090.6 million ( $€ 3.4$ billion, US\$5.0 billion, 300 percent of quota) Stand-By Arrangement was approved by the Executive Board on March 25, 2011 (Country Report No.11/80) and became effective March 31, 2011. The third tranche of SDR 430 million (€475 million) will be made available upon completion of this review. The authorities are treating the arrangement as precautionary. Funds under the program are also provided by the European Union (on a precautionary basis) and the World Bank.
\end{abstract}

Status of the current program: All end-June quantitative performance criteria were met. All but one of the indicative targets were also met. Inflation breached the inner band of the inflation consultation mechanism, and concomitant consultations with staff were held during the mission. Two structural benchmarks are expected to be met by the board meeting, with a third reset to end-October. There is one prior action for the board meeting: a further adjustment in nonresidential gas prices.

Key issues: The SBA review focused on three issues: (i) measures to assure compliance with the 2011 and 2012 fiscal targets while clearing arrears, improving quality of spending and strengthening tax collections; (ii) progress on the structural reform agenda, with a focus on state-owned enterprise reforms and regulatory reforms; and (iii) safeguarding financial sector stability.

Discussions: Discussions were held in Bucharest, July 20-August 1, 2011. The mission met with President Basescu, Prime Minister Boc, Finance Minister Ialomiţianu, Central Bank Governor Isarescu, other senior officials, representatives of labor and business organizations, and financial institutions. The staff team comprised J. Franks (head), M. Stierle, and A. Tuladhar (all EUR); F. Salman (SPR); L. Eyraud (FAD); and M. Dobler (MCM). T. Lybek (Resident Representative) assisted the mission. Discussions were held jointly with the EC, ECB, and World Bank staff. 


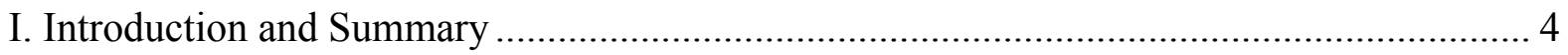

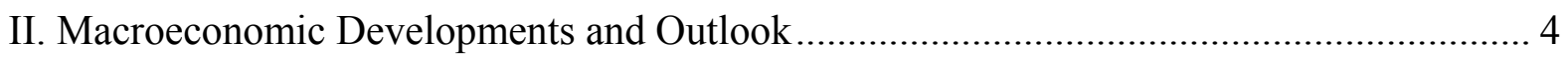

A. Recent Developments ......................................................................................... 4

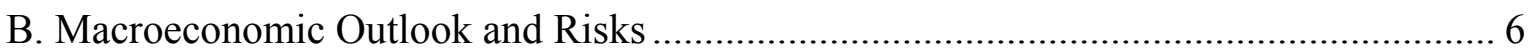

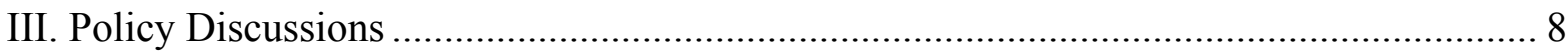

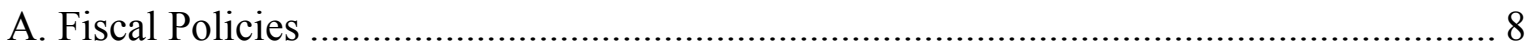

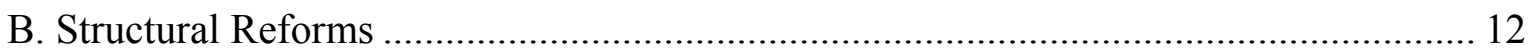

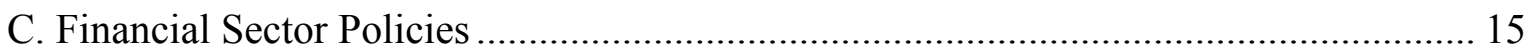

D. Monetary and Exchange Rate Policies..................................................................... 17

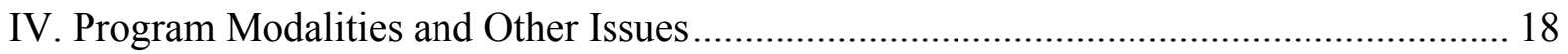

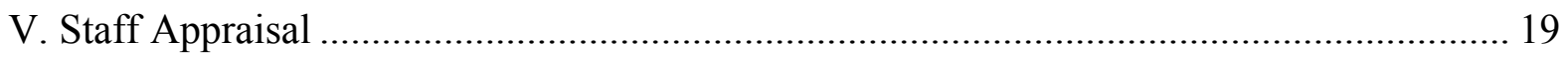

Box

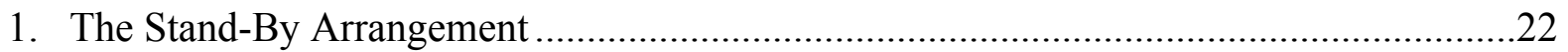

Figures

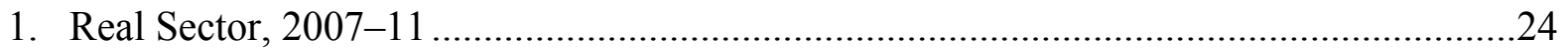

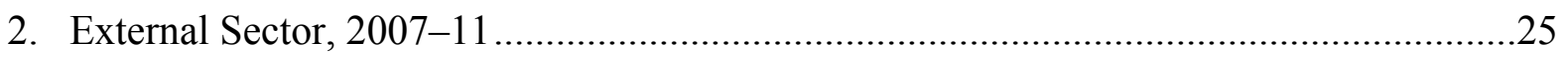

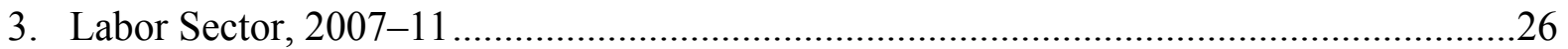

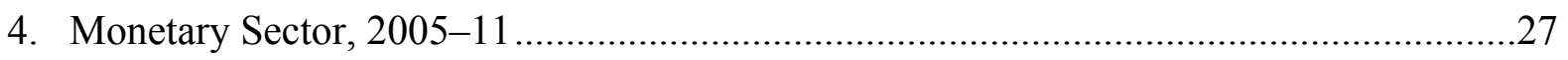

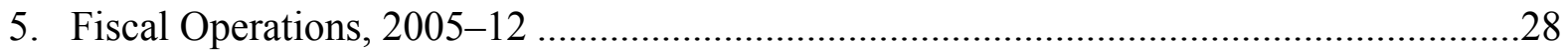

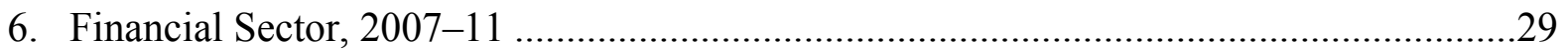

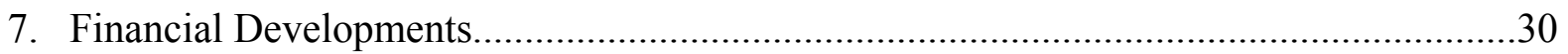

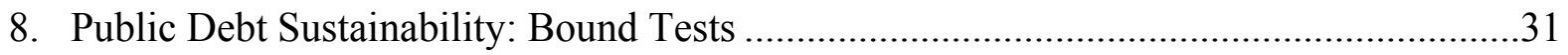

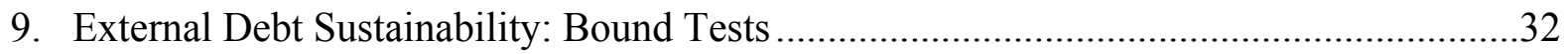

Tables

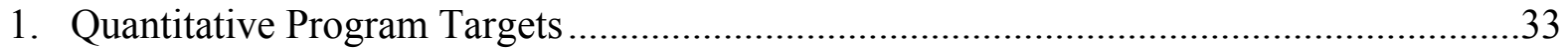

2. Performance for Second Review and Proposed New Conditionality .................................34

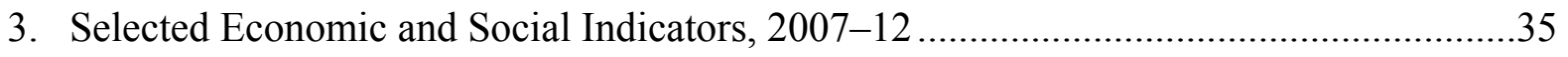

4. Macroeconomic Framework, Current Policies, 2008-16 .................................................36

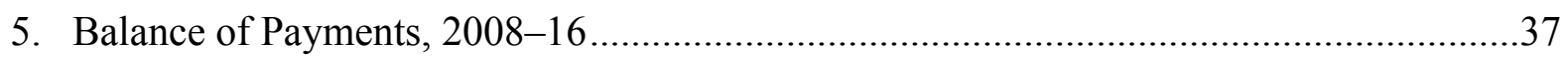

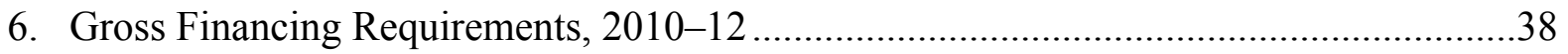

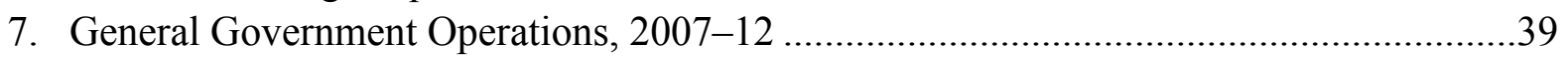

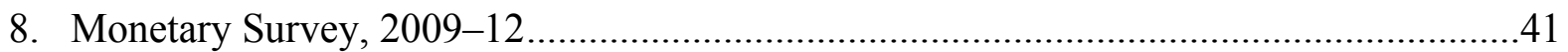

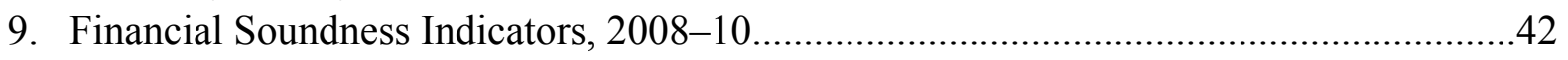




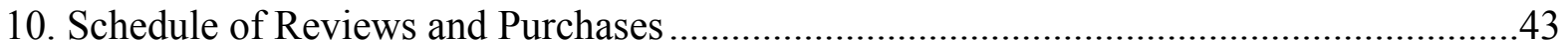

11. Indicators of Fund Credit, 2011-16 .......................................................................44

12. Public Sector Debt Sustainability Framework, 2006-16 ............................................45

13. External Debt Sustainability Framework, 2006-16.....................................................46 


\section{INTRODUCTION AND SUMMARY}

1. Economic growth has resumed, but risks have risen. GDP growth has weakened in Q2, but a good harvest is expected to contribute to a rise of $1 \frac{1}{2}$ percent for 2011 as a whole. In 2012, growth is expected to accelerate to $3 \frac{1}{2}-4$ percent. However, recent developments in Europe have boosted downside risks. CDS spreads have widened sharply, the leu has lost gains experienced earlier in the year, and banking sector risks have heightened due to stresses in the euro area periphery. Inflation dropped sharply in June-July, but is still expected to remain above the central bank's inflation target ( 3 percent \pm 1 ppt.) in 2011 before returning to the target range in 2012. Strong export performance is expected to stabilize the current account deficit below 5 percent in 2011-12.

2. Romania has continued its strong performance under the new program. The authorities met all performance criteria for the second review, and met all indicative targets except that on SOE arrears. The structural benchmark on SOEs reforms has been partially met, and the remaining actions are expected to be completed by the time of the board meeting. The structural benchmark on eliminating the legal basis for the stimulente funds is also slated for completion by the time of the board meeting. The benchmark on SOE governance reform legislation has been postponed to October 31, to allow proper preparation time.

\section{Implementing the ambitious structural reform agenda and achieving the fiscal} goals for 2012 will be challenging. Fiscal performance is on track to meet the 2011 deficit target, and the authorities' current plans for 2012 could deliver a deficit of under 3 percent of GDP in cash terms. However, reaching the authorities commitment to the EU of under 3 percent of GDP in accrual (ESA) terms will require additional adjustment of at least $1 / 2$ percent of GDP to cover the inclusion by Eurostat of additional entities into the general government, as well as the traditional gap between cash and accrual totals. Such measures would have to be identified in a follow-up mission. The authorities are moving forward with plans to improve the governance and regulation of SOEs in the energy and transport sectors, as well as plans for restructuring and/or privatization of key firms. However, these reforms are both technically demanding and politically difficult, with political constraints likely to intensify as the 2012 elections approach.

\section{MACROECONOMiC DeVElopments AND OUTLOOK}

\section{A. Recent Developments}

4. Growth has returned to Romania, but the recovery remains fragile. The country posted its third consecutive quarter of positive growth in Q2, although the pace weakened to 0.2 percent $(\mathrm{q} / \mathrm{q})$. Domestic demand began to recover, while net exports turned slightly negative. High frequency indicators suggest weaker growth in industrial production and exports. Consumer confidence, however, continues to improve while the monthly decline in retail sales has started to reverse, as has the construction sector. Furthermore, an excellent 
agricultural harvest should boost growth. Job losses have halted, and registered unemployment rate continued to fall to 4.8 percent in July; however, the more representative ILO measure showed a rate of 7.3 percent in July.

\section{Inflationary pressures have fallen}

sharply. CPI inflation dropped to 4.9 percent in July from its peak of 8.5 percent in May, reflecting a large decline in food prices and the elimination of the 2010 VAT increase from the 12-month index. Core inflation ${ }^{1}$ also fell to 3.1 percent (from 3.6 percent). With the labor market gradually stabilizing, wages are starting to rise in nominal terms, but real wages and unit labor costs are still declining.

\section{Since June, financial markets have} displayed some nervousness regarding spillover effects from the difficulties elsewhere in Europe. Between January and May, the sovereign CDS spread narrowed by around 60 basis points and Romanian equity markets gained more than $5 \frac{1}{2}$ percent. Portfolio inflows rose, and the authorities also successfully launched a euro medium-term note issue in June for $€ 1.5$ billion, which was well-subscribed. They also continued to build the domestic yield curve, with successful treasury bond auctions out to 10 years maturity at reasonable interest rates. In July, Fitch upgraded Romania's long term foreign currency rating to investment grade. The leu also appreciated somewhat by 3 percent against the euro. However, these gains have been reversed since early June, as CDS spreads have risen by some 90 basis points and the lei has given back its gains.
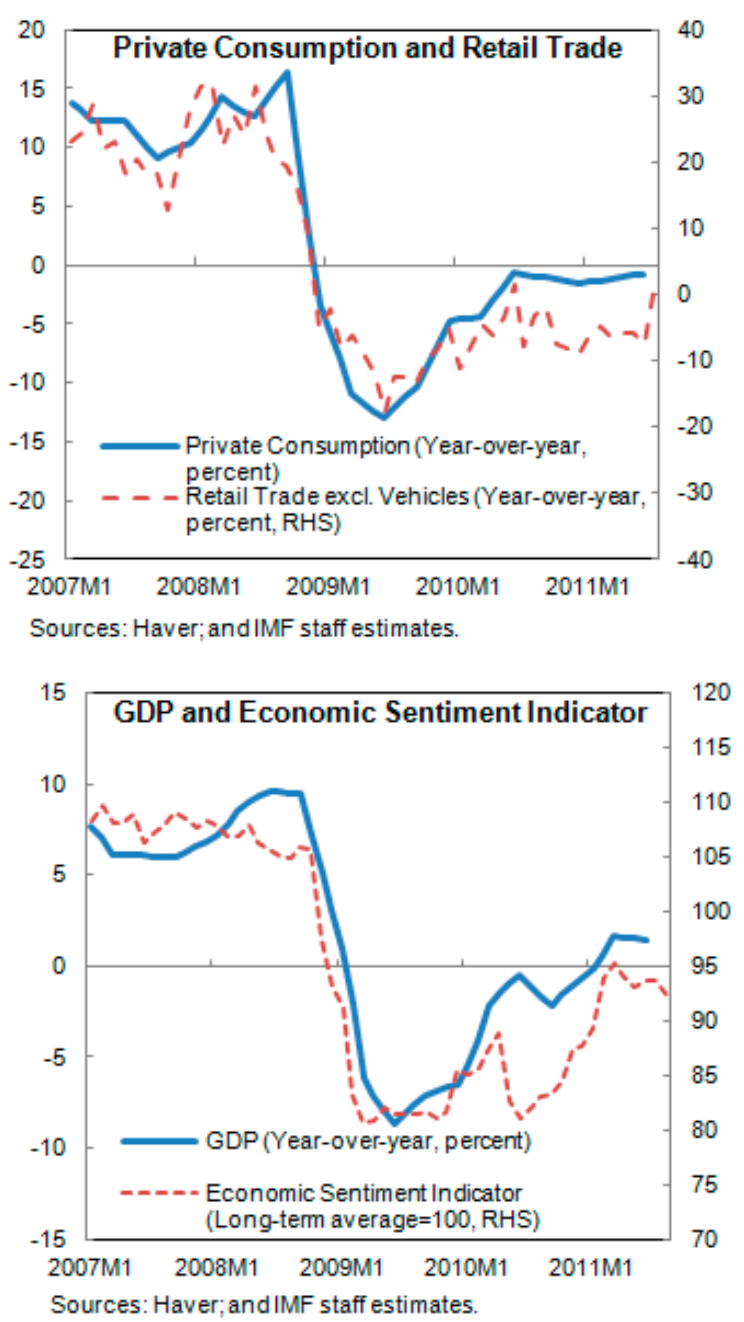

International reserves at end-July 2011 remained comfortable at nearly 35 billion euros, covering short-term debt at residual maturity.

\footnotetext{
${ }^{1}$ As measured by the Core 3 indicator, which excludes energy, administered prices, unprocessed foods, alcohol, and tobacco.
} 

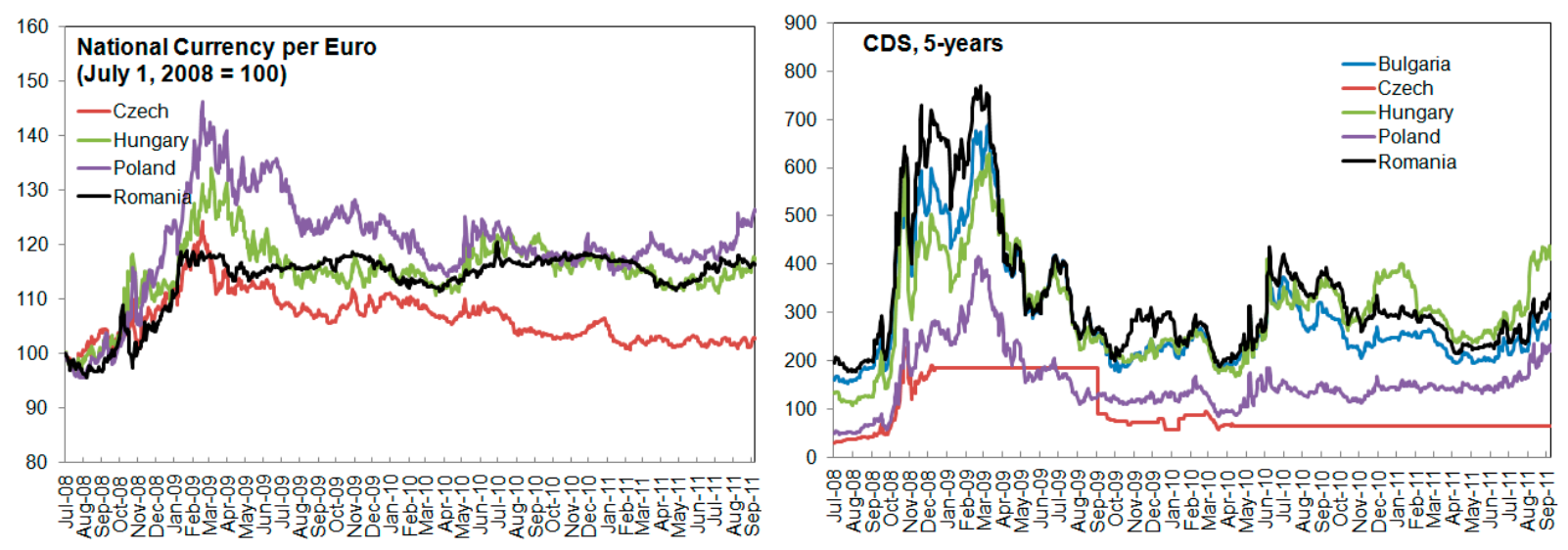

Sources: Haver, Bloomberg; and IMF staff estimates.

7. Romania's external position continues to improve. The current account deficit improved from 13.4 percent of GDP in 2007 to 4.1 percent of GDP in 2010, driven by a strong shrinking trade deficit.

Exports are booming with the recovery in major trading partners while subdued domestic demand continues to limit import growth. In the first half of the year, the trade deficit was down by 22 percent, and the current account deficit by 29 percent from the previous year. The trade balance continued to improve fueled by strong exports, particularly in the machinery and automotive sectors. With the help of the current

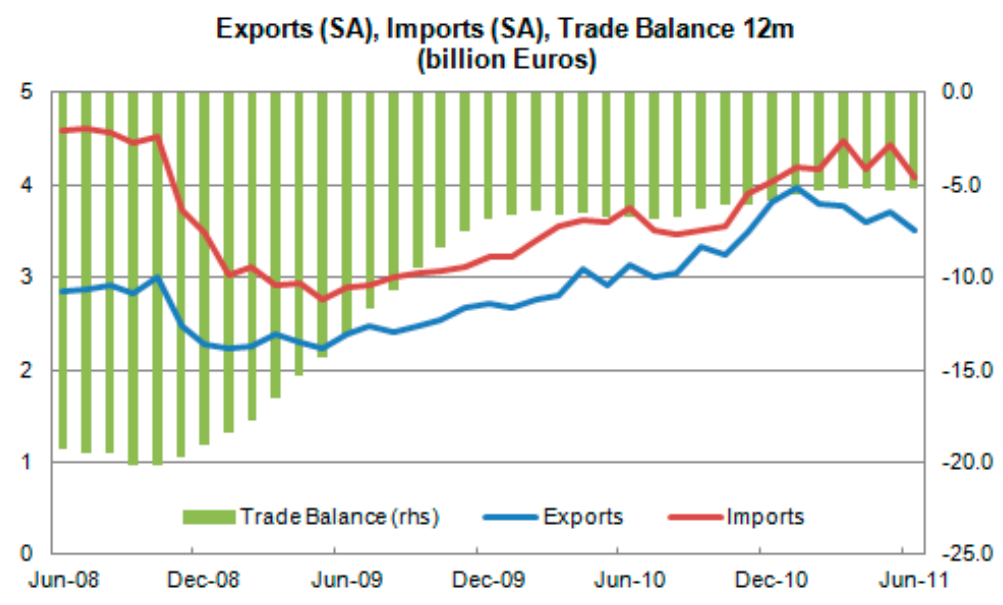
Source: Haver. transfers to the public sector, mainly due to disbursements from EU funds approved in 2010, the current account dropped to around 3 percent of GDP on a 12-month rolling basis through June.

\section{B. Macroeconomic Outlook and Risks}

\section{The baseline macroeconomic outlook remains favorable in 2011-12, but risks have risen sharply.}

- $\quad$ Growth is expected to reach $1 \frac{1}{2}$ percent in 2011, initially led by exports, with domestic demand recovering gradually in the second half of the year, reflecting good agricultural output and a recovery in the labor market. In 2012, growth is expected to accelerate to $3 \frac{1}{2}-4$ percent in 2012 , with the recovery shifting from external to domestic demand as consumption recovers and investment increases with rising EU funds absorption. Increased investor confidence, coupled with planned privatization under the program, are expected to bring renewed FDI and capital inflows. Staff's 
baseline projection is for growth to remain somewhat above the $3-3 \frac{1}{2}$ percent estimated increase in potential output in 2013-16, allowing for the output gap to close by 2016 .

- $\quad$ Headline CPI inflation is expected to recede to around 5 percent ${ }^{2}$ by the end of 2011 , as the effects of the July 2010 VAT increase drop out, partly offset by increases in administered prices. High world food and energy prices left inflation well above the previously forecast path, triggering consultation with staff under the inflation consultation mechanism of the Fund program in this review; however, the danger of breaching the limit in future reviews has eased. For 2012, a further

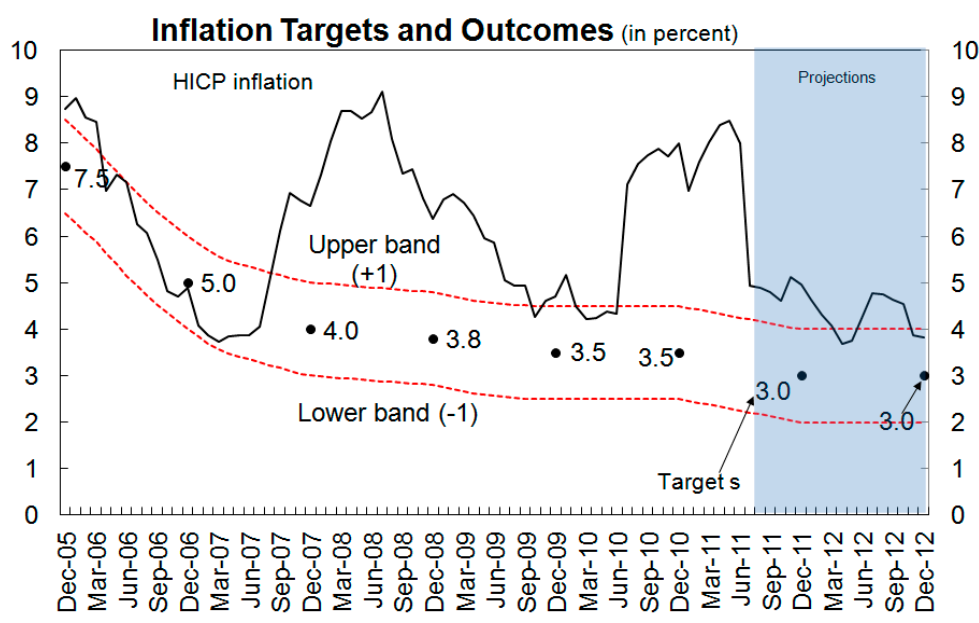
disinflation towards the central bank's target ( 3 percent +1 ppt.) is expected as these supply side shocks wear off.

- $\quad$ The current account deficit is projected to stabilize at below 5 percent of GDP in 2011-12. In line with recent strong growth in exports, the trade balance will improve in 2011, partly offset by repatriation of profits. Remittances are not expected to grow due to continued slack in host economies, such as Spain and Italy. Private capital inflows are expected to improve over the program period, with FDI rebounding from recession lows accompanied with strong public and private portfolio inflows. Under staff's baseline scenario, no new financing gap is envisaged, consistent with the program's precautionary nature.

\section{Risks to growth have tilted to the downside since the last review, while upside} risks dominate on the inflation front. Increased turbulence in world markets and signs of lower growth elsewhere in Europe have sharply increased downside risks. Romania is vulnerable both to a decline in demand for its exports and to financial market uncertainties, particularly from Greece, which could prompt capital outflows or spillover into the Romanian financial system. Strong capital buffers in banks, tight banking supervision, and healthy NBR reserves provide some cushion against these risks. Domestic political tensions and looming elections could also lead to policy reversals, dampening confidence. On the

\footnotetext{
${ }^{2}$ This forecast includes the elimination of heating subsidy at the central government level, which will contribute to a 0.6 percent increase in annual inflation.
} 
upside, more rapid implementation of structural reforms and faster absorption of EU-funded projects could catalyze faster economic growth and stronger capital inflows. Inflation risks are somewhat tilted to the upside. Further adjustment in administered prices, public wage increases and their knock-on effects could boost inflationary pressures. Underlying inflationary pressures are, however, mitigated by the still large output gap and a bumper harvest.

\section{Policy Discussions}

\section{A. Fiscal Policies}

10. The authorities remain on track to meet their 2011 cash deficit target of 4.4 percent of GDP. The end-June overall balance and primary spending targets were both met by a comfortable margin $(0.4$ and 0.3 percent of GDP, respectively). Tax revenues have been higher than anticipated, while both current and capital expenditure have been lower, producing a much smaller deficit. Personnel expenditure has been below projections due to a sharper-thanexpected reduction in public employment. Capital spending has also fallen significantly short of forecasts, with EU structural funds projects continuing to underperform.

\begin{tabular}{|c|c|c|c|}
\hline \multicolumn{4}{|c|}{$\begin{array}{l}\text { Fiscal Performance, Second Quarter, } 2011 \\
\text { (billions, RON) }\end{array}$} \\
\hline & 1st Rev. & Actual & Difference \\
\hline Total revenue & 45.7 & 43.4 & -2.3 \\
\hline Tax revenue & 37.1 & 38.2 & 1.2 \\
\hline Nontax revenue & 5.0 & 3.9 & -1.1 \\
\hline Grants & 3.7 & 0.9 & -2.7 \\
\hline Other & -0.1 & 0.3 & 0.4 \\
\hline Total expenditure & 54.5 & 49.4 & -5.0 \\
\hline Personnel & 10.7 & 9.8 & -0.8 \\
\hline Goods and services & 7.2 & 7.7 & 0.5 \\
\hline Interest & 2.8 & 2.4 & -0.4 \\
\hline Subsidies & 1.2 & 1.2 & 0.0 \\
\hline Transfers & 25.8 & 22.5 & -3.3 \\
\hline Capital & 5.8 & 5.3 & -0.5 \\
\hline Other spending & 1.0 & 0.4 & -0.7 \\
\hline Deficit/Surplus & -8.8 & -6.0 & 2.8 \\
\hline \multicolumn{4}{|l|}{ Memo item: } \\
\hline Total capital spending & 11.7 & 9.1 & -2.6 \\
\hline Revenues excluding EU grants & 42.0 & 42.5 & 0.4 \\
\hline
\end{tabular}

11. The budget supplement adopted in August slightly raises spending in 2011. The revenue forecast has been revised upward by 0.2 percent of GDP, reflecting improved tax collection performance (particularly in excise taxes). The authorities intend to use the extra revenue to provide for a higher-than-expected number of pensioners, and to cover unpaid bills and additional expenditure pressure in the health sector. Additional allocations to the health sector will be strictly tied to the adoption of healthcare reforms to avoid recurring arrears pressure in the future ( $\$ 16)$. If lower public employment creates sufficient space, the authorities may consider a modest wage increase later in the year, while remaining within their original wage bill limit. In the context of the SOE reform program, the budget supplement also allocates, in the form of transfers, 0.3 percent of GDP to the reduction of SOE arrears to be used to catalyze a much larger reduction in overall SOE arrears via cancellation schemes; however, these plans are expected to be budget-neutral, as they will be offset by the recovery of tax arrears.

12. The authorities retain their commitment to bring down the deficit to under 3 percent in 2012. Preliminary budget preparation is based on a cash deficit of 2.8 percent of GDP, generating an additional improvement in the structural fiscal balance of just over 
1 percent of GDP. The authorities' plan assumes savings from reforms already implemented such as pension reform, means testing for social programs, and continued expenditure restraint, especially on the wage bill and subsidies. Health reforms should also contribute (\$16). The capital budget will be preserved, but greater focus will be placed on EU fund absorption (LOI 912 ) and on project prioritization after the comprehensive review of existing projects is completed by end-September (structural benchmark). Successful achievement of the agreed adjustment would require that the authorities resist political pressures to reduce social contribution rates, to increase infrastructure spending in the Ministry of Regional Development, or to hike wages more quickly than the gradual path agreed in the preliminary budget ( $(14)$.

\section{While a cash deficit of under 3 percent of GDP appears achievable based on the} preliminary budget proposed by the authorities, reaching the authorities' commitment to the EU of under 3 percent of GDP in accrual (ESA) terms will prove challenging. First, the gap between ESA and cash deficit measures has traditionally been on the order of $1 / 2-3 / 4$ percent of GDP, meaning another $1 / 4-1 / 2$ point of GDP in adjustment would be necessary. ${ }^{3}$ Second, Eurostat's pending decision to add additional SOEs into the general government definition could perhaps add another $1 / 4$ percent of GDP to the deficit. ${ }^{4}$ Thus, a further adjustment of $1 / 2-1$ percent of GDP would likely be required to make the EU target in accrual terms.

\section{Ambitious reductions in} public employment have created some fiscal space to restore public wage cuts. The 25 percent wage reduction in 2010 was combined with a sharp drop in public employment, which allowed

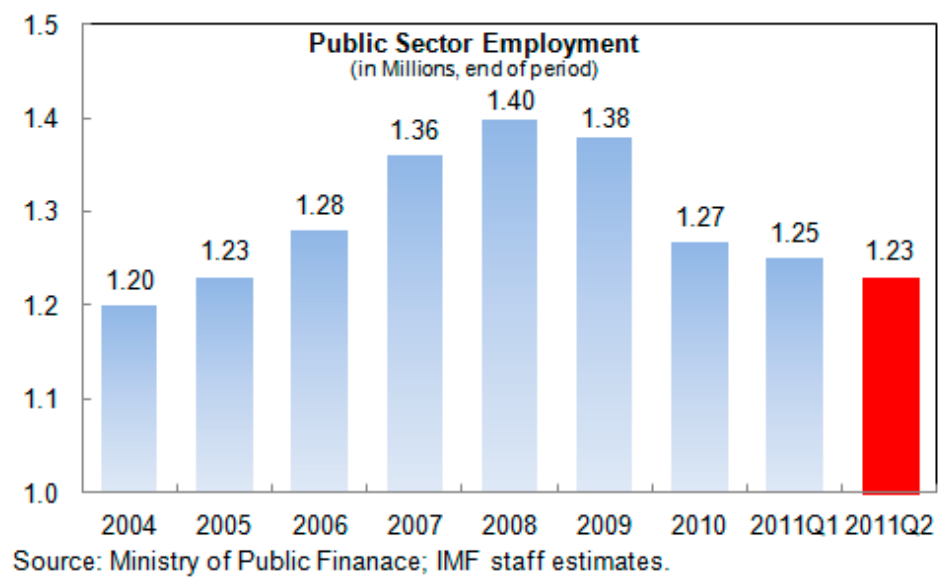
for a partial restoration in the 2011 budget (via an increase of 15 percent). During 2011, public employment has continued to decline - more rapidly than originally envisagedleaving room to gradually reinstate the remainder of the wage cut by end-2012 - as mandated by the Constitutional Court. The timing and amount of increases will be conditioned on further progress in reducing public employment so as to maintain the total wage bill at

\footnotetext{
${ }^{3}$ The authorities are designing a monitoring system to obtain timely information from these SOEs. Once it is fully functional, the performance criterion on general government overall balance in 2011 will be amended to include the operating balance of these entities.

${ }^{4}$ Under Eurostat rules, an SOE must be included as part of the general government when more than half of its resources come from the state over a three year period. Several Romanian firms fall within this threshold and will be folded into the general government statistics in the course of 2011.
} 
7.5 percent of GDP in 2011 and 7.2 percent of GDP in 2012, down from 91/2 percent of GDP in 2009 .

\section{Arrears are decreasing but challenges remain in local governments, SOEs, and}

\section{the health sector ( $\mathrm{LOI} 99$ ).}

- Central government and social security arrears met the Q2 performance criterion, and as such remain near zero. However, significant unpaid bills exist in the health sector which the authorities must pay in order to avoid the accumulation of new arrears in the remainder of the year.

- In local governments, provisions of the new local public finance law have started to bear fruit, with local arrears decreasing by about RON 100 million in the first semester. ${ }^{5}$

- In contrast, SOE arrears have continued to increase and further efforts are needed to reverse this trend (LOI $\mid 22-25) .{ }^{6}$ SOE arrears of monitored companies amount to 3.6 percent of GDP, with additional arrears reported in SOEs outside of those monitored under the program. The authorities have prepared a series of schemes to clear SOE arrears via netting arrangements, debt swaps, recapitaliation of firms, arrears securitization and government lending, and/or guarantees. These arrangments are expected to reduce arrears by up to 1 percent of GDP by year-end. The authorities will also restructure SOEs at the same time to preclude accumulation of new arrears.

\footnotetext{
${ }^{5}$ These provisions include mandatory allocations for unpaid bills, multi-year budgeting, commitment control mechanisms, borrowing rules, and safeguards against revenue overestimation.

${ }^{6}$ Strategies to reduce SOE arrears include bankruptcy procedures, installment agreements, netting-out schemes among public institutions, provision of public resources via credits or debt-equity swaps (with the clearance by EU competition authorities), restructuring, and securitization.
}

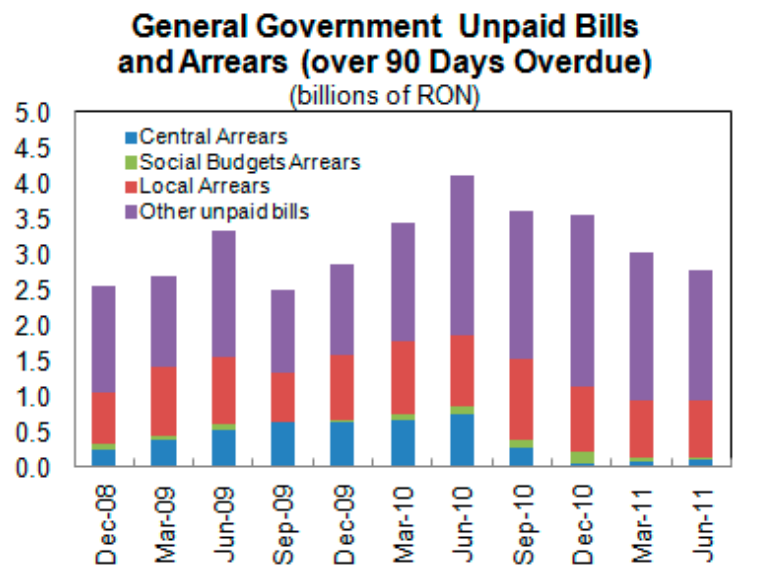

Source: Romania authorities; IMF staff estimates. 
16. The authorities will implement a comprehensive health reform in 2012 to address the structural deficits of the healthcare system. Past measures, such as the closure of small hospitals or the clawback tax on pharmaceuticals, have failed to generate the anticipated savings and the authorities have agreed on the need for a more comprehensive approach. Comprehensive amendments to the health care legislation will be prepared by endDecember 2011 (structural benchmark) with two key objectives (LOI 915 ):

- Contain the growth of health spending, by (i) reviewing the package of benefits insured by the government to exclude costly nonessential health services; (ii) revising the list and price of compensated drugs; and, (iii) further promoting the use of generics.

- Ensure adequate financing. Public healthcare spending in Romania is among the lowest in the EU as a share of GDP and budget allocations should be sufficient to cover realistic spending programs. Additional sources of revenue will also be needed to reduce budgetary shortfalls; the authorities proposed to (i) introduce copayments for medical services; (ii) create a supplementary insurance contribution to finance over-the-basic coverage (with a Table: Public Health Spending in EU Countries (Share of GDP)

possible private option); and, (iii) revise and simplify the clawback tax on pharmaceuticals (structural benchmark).

\section{The financing strategy remains focused on extending the maturity of the} domestic debt and consolidating financing buffers. The authorities have made progress in building the domestic yield curve, with the average maturity on domestic government debt rising from 2.7 years at end-December 2009 to 4.1 years at end-June 2011. The authorities launched the euro medium-term note program with a first issue in June and plan to continue regular external bond issuances both in euros and dollars. To protect government finances against external shocks, the authorities are building up foreign currency buffers, with a view to maintain at least four months of gross financing needs. Technical assistance missions provided by the IMF, European Commission (EC), and World Bank (WB) are also helping to strengthen the authorities' debt management capacity and strategy.

\section{The authorities continue to suffer from difficulties in improving EU structural} funds absorption and prioritizing capital spending. The level of projects contracted under EU funded projects has increased significantly in recent months, but certified absorption remains weak, and difficulties have recently surfaced in some of the expenditures submitted for reimbursement, causing the government to pause reimbursement applications until the difficulties are resolved. Efforts are underway to strengthen the administrative capacity of units managing the funds, including by providing expert assistance to help beneficiaries in all project stages. The authorities have started prioritizing investment projects to release 
cofinancing funds for EU related projects. The database of all investment projects at the central level was completed in June, and a final report with an action plan on prioritizing investment is expected by end-September (structural benchmark). The government will also amend public procurement legislation to bring it in line with EU requirements, and will develop standard bidding documents for key sectors to reduce contested tenders.

\section{Tax administration reforms continue aimed at facilitating improved tax}

compliance and reducing collection costs. The authorities have prepared a plan to promote the use of indirect audit methods in order to assess tax liabilities. They passed the government decision on ANAF restructuring and have closed 141 regional offices. An ordinance was adopted in August to eliminate the legal basis of the stimulente funds (structural benchmark). Going forward, the authorities intend to introduce a simplified tax regime for small taxpayers in 2012 (end-December structural benchmark) and have already requested from the EU an increase in the VAT mandatory threshold. Based on the recommendations of the IMF technical assistance mission of July, the authorities will also improve VAT refund processes and expand the tax audit of large taxpayers.

\section{B. Structural Reforms}

\section{State-Owned Enterprises}

20. Deep-rooted SOE reform remains crucial for increased economic growth and sustained fiscal adjustment. The stocktaking exercise on public companies has revealed more firms than previously recorded (particularly in local governments) and the size of arrears is significantly higher than previously anticipated. Reform measures under the program are beginning to bear fruit, but significant additional effort is needed. The operating losses of firms monitored under the program have fallen, restructuring efforts are underway, and plans for arrears reduction and full and partial privatizations are advancing.

21. Initiatives to improve SOE governance are advancing. Under the program, legislation is being prepared which will require regular independent external audits, quarterly publication of financial data, and reinforcement of OECD principles on corporate governance (structural benchmark). Private management experience will be brought into the largest SOEs that remain under majority government ownership. Financial control of SOEs will be moved from line ministries to the MOPF and will include enhanced reporting mechanisms. Action plans were prepared to restructure the SOEs and reduce their arrears (structural benchmark, LOI $\uparrow 7$ and $\uparrow 22)$. 


\section{Restructuring of SOEs is progressing, including an envisaged significant} reduction of arrears. Restructuring plans are being finalized for about 150 central government SOEs, and those for the 18 SOEs monitored under the program are being implemented. For companies newly integrated into the database of the MOPF, restructuring plans will be developed before year-end. Arrears reduction plans have been identified for specific companies, envisaging a reduction of nearly 1 percent of GDP. The MOPF and line ministries continue efforts for additional arrears reductions, while maintaining

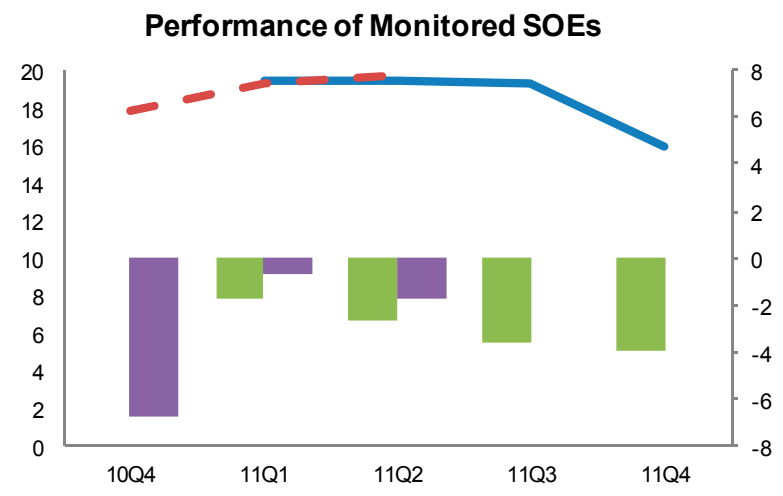
consultations with EU competition authorities to avoid state-aid related market distortions ( $\mathrm{LOI} \uparrow 9$ ).

\section{First steps in the privatization process have been taken, but obstacles may} impede timely sales of stakes in companies. The recent offer of a 10 percent stake in Petrom, a profitable company with private majority ownership, was unsuccessful. While this may have been due to the pricing and timing of the offer rather than a fundamental lack of interest in Romanian companies, unsettled international market conditions may affect the agreed timetable for sales. Nevertheless, the government remains committed to the agreed calendar for privatization. The government is preparing to sell the remainder of chemical company Oltchim, and minority stakes in airline Tarom, and energy companies Romgaz, Transelectrica, and Transgaz. Legal advisor for most of these firms have been appointed. A second group of companies will include minority stakes in Hidroelectrica and the second attempt to sell the 10 percent stake in Petrom in early 2012. A third group includes minority stakes in Nuclearelectrica and majority privatizations of the governments remaining distribution, as well as supply companies and major electricity producers later in 2012. The transaction advisors for group one and the legal advisors for group two will be appointed by end-October as crucial steps in the process (structural benchmark). In the event that international market conditions impede timely privatizations, alternative actions will be agreed to improve operations in those firms. 


\section{In the energy sector, restructuring measures and regulatory reforms aim at} attracting private investment. After three years of unsuccessful efforts to form two national "champions," the government has agreed to pursue an alternative strategy, with smaller energy companies and a greater role for private capital. In addition to the minority stakes to be sold in major energy companies, the authorities are continuing with plans to phase-out unprofitable coal operations while spinning-off viable mines. They are also proceeding with plans to separate viable entities in energy producer Termoelectrica while winding-up other operations. To avoid further arrears accumulation in district heating companies, local governments will be required to budget and pay heating subsidies if they envisage a lower consumer price than recommended by the regulator. To address pricing and regulatory framework deficiencies, steps are under preparation to restore the energy regulator's (ANRE) operational and financial autonomy, and additional steps are envisaged to liberalize the energy market (LOI 126 ). To better balance the gas market, the CUG for non-residential customers will be increased by 8 percent as a prior action as part of a phased plan to align prices with a formula-based approach that ensures full cost recovery. Once the CUG formula price is fully reached, the authorities will continue to adjust nonresidential prices to reach international prices by end-2013, and residential prices will be gradually adjusted thereafter to reach international rates by end-2015. The authorities will take necessary steps to terminate existing below market bilateral contracts of state-owned gas and electricity generators and new contracts will be conducted fully transparently.

25. In the transport sector, steps to improve infrastructure and increase efficiency in service provision are underway. Major infrastructure projects using EU structural funds have been approved and project execution is beginning. Revenues will be increased through tariff adjustments and enhanced toll collection, while costs will be reduced by better aligning staffing, refocusing services, extending the use of standard costs for contracts as well as enhanced control mechanisms. These measures include a reduction of the rail network maintained by the public infrastructure company to 5,500 line $\mathrm{km}$ via line closures and tendering lines out. To bring in private management and capital, the authorities will offer minority stakes in the national air carrier (Tarom) and appoint private professional management for all main rail companies and Tarom.

\section{Other Reforms}

\section{The authorities have undertaken important reforms in labor legislation and} social protection. The new Labor Code, enacted April 30, aims to promote fixed-term and temporary employment, extend probation periods, and increase the flexibility of working hours. A substantial number of new contracts $(600,000)$ have been registered since April, perhaps reflecting early improvement in registering previously underground employment. The authorities are continuing making efforts to streamline social assistance while protecting the vulnerable through means-testing of benefits. A new Social Assistance Code has been drafted to consolidate the existing 54 categories of social benefits into 9. Social inspection has yielded significant results, as the number of beneficiaries of heating allowances has declined by half in 2011. The overall measures on social benefit reforms will result in fiscal 
savings of around 0.8 percent of GDP in 2010-13. Judicial reforms are also underway to improve the efficiency of the legal system and reduce corruption.

\section{Financial Sector Policies}

\section{There are emerging signs of a tentative recovery in lending and the banking system remains well capitalized, but risks have risen from difficulties elsewhere in}

Europe. Lending picked up in the second quarter of 2011, which more than offset the contraction over the previous quarter. The average capital ratio for the system was 14.2 percent as of end-June with the pace of the increase in non-performing loans slowing slightly. Sustained improvement remains dependent upon the economic recovery gaining traction, with the risks on the downside due to potential spillovers from the European periphery. As of end-July 2011, the aggregate exposure to Romania of the nine largest foreign banks participating in the European Bank Coordination Initiative stood at 95 percent of the level when the initiative commenced, down from over 98 percent the month before, perhaps reflecting recent international market turbulence. ${ }^{7}$

Romanian Banking System - Core Indicators (in percent)

\begin{tabular}{|c|c|c|c|c|c|c|}
\hline & Dec-08 & Dec-09 & Jun-10 & Dec-10 & Mar-11 & Jun-11 \\
\hline \multicolumn{7}{|l|}{ Capital adequacy } \\
\hline Capital adequacy ratio & 13.8 & 14.7 & 14.3 & 15.0 & 14.9 & 14.2 \\
\hline Leverage Ratio $^{1 /}$ & 8.1 & 7.6 & 7.9 & 8.1 & 8.0 & 7.8 \\
\hline \multicolumn{7}{|l|}{ Asset quality } \\
\hline Non-performing loan ratio ${ }^{2 /}$ & 2.8 & 7.9 & 10.2 & 11.9 & 12.7 & 13.4 \\
\hline Loan loss ratio ${ }^{3 /}$ & 6.5 & 15.3 & 17.8 & 20.8 & 22.0 & 21.9 \\
\hline \multicolumn{7}{|l|}{ Profitability } \\
\hline Return on assets & 1.6 & 0.2 & -0.1 & -0.2 & 0.5 & 0.1 \\
\hline Return on equity & 17.0 & 2.9 & -1.6 & -1.7 & 5.0 & 0.6 \\
\hline \multicolumn{7}{|l|}{ Liquidity } \\
\hline Loans to deposit ratio & 122.0 & 112.8 & 117.5 & 113.5 & 114.8 & 118.4 \\
\hline Immediate liquidity ratio ${ }^{4 /}$ & 34.4 & 35.3 & 35.9 & 37.9 & 37.2 & 36.3 \\
\hline
\end{tabular}

Source: NBR.

$1 /$ Tier 1 capital / total average net assets.

2/Unadjusted exposure from loans classifieds as "loss" defined as past 90 days and/or initiation of legal preceding / total loans and interest, excluding off-balance sheet items.

3/Unadjusted exposure from loans and interest falling under "doubtful" and "loss" / total classified loans and interest, excluding off-balance sheet items.

4/Cash, sight and term deposits with banks plus government securities free of pledge / total liabilities.

\footnotetext{
${ }^{7}$ While they have not set a specific target exposure level going forward these banks have affirmed their long term commitment to the country and continue to report exposures.
} 
28. The NBR remains vigilant to weaknesses in the banking system which may be exacerbated by spillovers from the European periphery. The NBR remains alert to the risk of spillovers from the European periphery as well as from uncertainties in euro area parent banks. ${ }^{8}$ Greek banks operating in Romania in aggregate hold around 16 percent of system assets, but they remain well-capitalized, although they generally pay somewhat higher deposit rates than the market average. The NBR stands ready to provide liquidity as necessary to mitigate segmentation in the interbank market and is refining its full range of contingency measures to deploy if necessary to preserve depositor confidence. Some small- and medium-sized banks with high cost ratios, rising loan impairments, and lower than average provisions continue to incur losses. Further capital will be required in some cases, under the continued close oversight of the supervisor. ${ }^{9}$ A salutary trend for consolidation in the banking sector may be emerging, as evidenced by the recently announced merger of Alpha Bank and EFG Eurobank, which will also join their operations in Romania.

\section{Progress continues on strengthening contingency planning and banking}

regulation. Significant progress has been made in finalizing the outstanding benchmark to enable the Deposit Guarantee Fund (DGF) to finance the new bank resolution and restructuring tools, such as purchase and assumption (modified benchmark). In addition, and as part of ongoing contingency planning, the authorities are committed to passing legislation which would provide for bridge bank powers to strengthen the range of bank resolution tools available. The authorities are finalizing the regulatory framework and tax treatment for filters for provisioning that will preserve the current prudent approach once International Financial Reporting Standards are introduced for banks at the beginning of 2012. The NBR will also shortly issue new regulations ${ }^{10}$ to discourage un-hedged consumer borrowing in foreign currency to reduce the risk of further euroization of lending, including steps to tighten the regulatory treatment of banks' foreign exchange lending.

\footnotetext{
${ }^{8}$ For a discussion of spillover risks, see the recent IMF Euro Area Spillover Report, http://www.imf.org/external/pubs/cat/longres.aspx?sk=25056.0.

${ }^{9}$ In aggregate, these banks comprise less than 7 percent of the market share.

${ }^{10}$ These regulations do not cover mortgage lending due to concerns about market impact. Housing in Romania is priced in euros and long term loans are denominated in foreign currency (primarily euros) as the domestic yield curve remains liquid at short maturities only.
} 


\section{Monetary and Exchange Rate Policies}

\section{Notwithstanding the recent drop in inflation, the central bank is vigilant against inflation risks and remains committed to take action as needed to assure achievement of} its 2012 inflation target. The NBR has held policy rates stable since May 2010 and shifted to a tightening bias owing to increasing inflationary concerns. As the inner program band was exceeded at end-June, staff held consultations with the authorities on inflation during the review mission. With inflationary pressures now starting to recede and little evidence of second round effects thus far, the central bank did not see an immediate need for an increase in policy rates. Nevertheless, the authorities remain concerned about upside risks stemming from expected increases in administered prices. ${ }^{11}$ Staff agreed that immediate action was no longer needed, but noted that additional exchange rate weakness could also translate into higher prices. They noted that open market operations will be continued to mop up excess liquidity and bring interbank rates closer to the policy rate. ${ }^{12}$ Staff cautioned, however, that in light of gathering risks of contagion from financial disturbances in the region and possible capital outflows, any
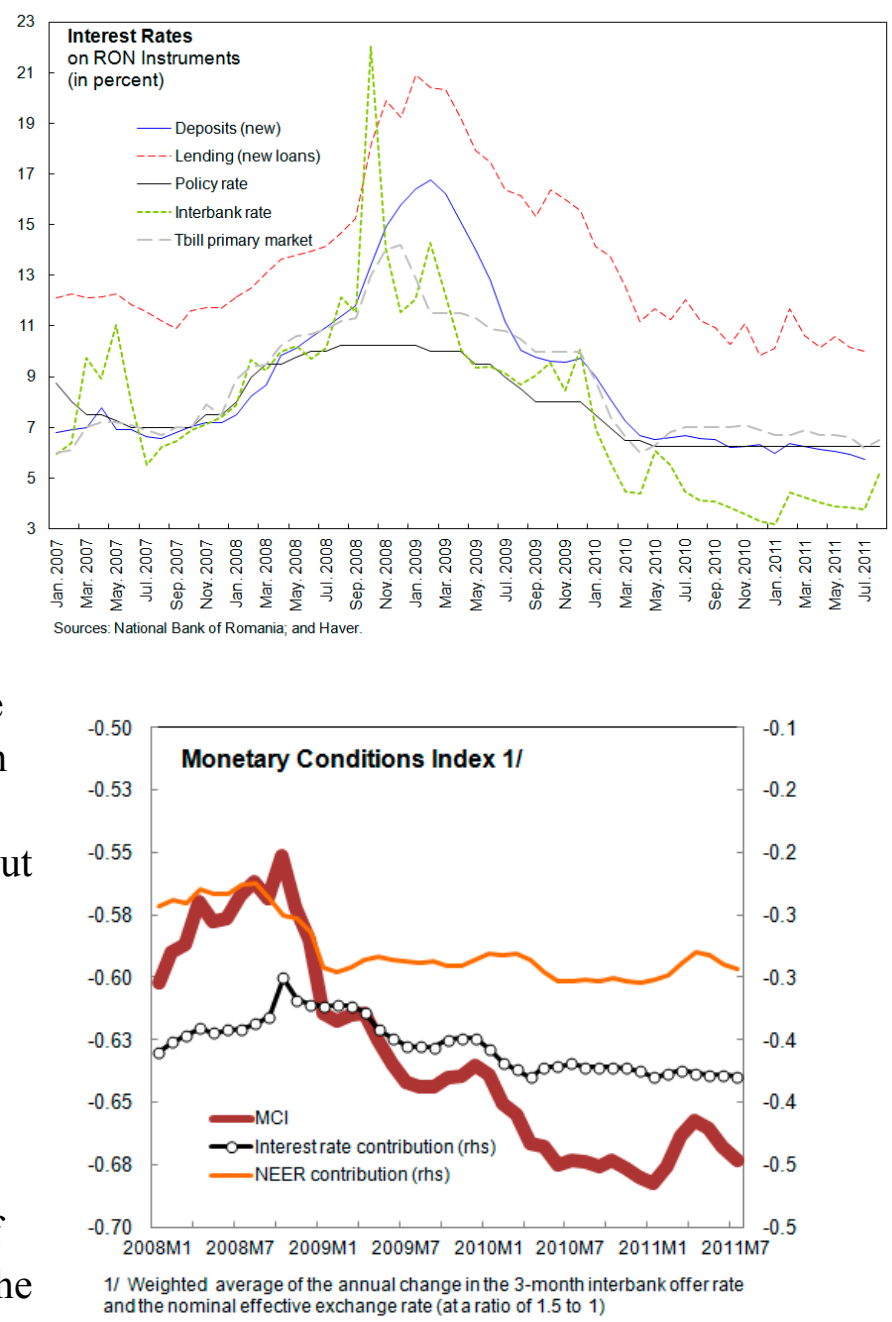
foreign exchange intervention should be aimed towards increasing reserve buffers rather than mopping up leu liquidity, and that a hike in the policy rate would be needed if headline inflation remains higher than the currently projected path in the coming months. The mission

\footnotetext{
${ }^{11}$ Staff estimates the impact of reducing heating subsidies at about $1 / 2$ ppt. on consumer prices. Transport prices for passenger rail and the Bucharest metro were hiked by 18 percent in August, but the impact on the CPI is likely to be minimal unless second round effects occur, as the weight in the index is low.

12 Romania has a large spread for its facilities around its policy rate (400 basis points, where the upper bound is the Lombard rate and the lower bound is the overnight standing facility). Over the past year, excess liquidity has led to a heavier reliance on the overnight standing facility which has allowed the interbank rate to come closer to the lower end of the band.
} 
also noted that the NBR should avoid letting considerations of its own balance sheet unduly affect its choice of monetary policy instruments.

31. Romania's competitiveness remains adequate. The depreciation in recent months has partially reversed the appreciation of the REER experienced earlier in the year.

Romania's exports continue to gain world market share and staff's exchange rate assessment based on extended CGER analysis does not show a misalignment in the currency.

32. Reserve coverage of short-term liabilities remains above $\mathbf{1 0 0}$ percent. The rise in gross international reserves in the first half of the year was partly offset by the heavy net repayment of Treasury's domestic euro liabilities by around $€ 2.6$ billion in July. The change in the profile for fiscal financing (aimed at extending maturities of existing issues and efforts to build the yield curve), coupled with volatility in international financial markets, shifted the projected reserve accumulation to the last quarter of the year (LOIף29).

\section{Program Modalities ANd Other Issues}

\section{The attached Letter of Intent (LOI) describes the authorities' progress in} implementing their economic program and sets out their commitments through end-December 2011. Some modifications to the program's conditionality are proposed (Tables 1-2):

- $\quad$ One prior action is proposed: for an increase of 8 percent in the CUG gas price for nonresidential consumers, which is essential to help normalize the gas market and avoid losses in SOEs.

- $\quad$ A modification in the end-September NFA target is proposed. The end-year target is unchanged, but the end-September target is proposed to be reduced from 500 to 250 , reflecting a change in the profile of fiscal financing ( $\mid 32)$

- $\quad$ Revisions to the timeframe for achieving the structural benchmarks are proposed: (Table 2) In view of the administrative and legal feasibility within the stipulated timeframe, the target date for meeting the structural benchmark for: (i) approval of new legislation on SOE corporate governance is shifted to Oct. 31, 2011; and (iii) Amending legislation to allow the DGF resources to facilitate bank restructuring is brought forward to Sept. 30, 2011.

- $\quad$ New structural benchmarks are being added: (Table 2) (i) As part of the restructuring and privatization strategy, appointment of legal advisors and/or privatization advisors in certain SOEs in preparation for privatization tenders by October 31, 2011;

(ii) approval by executive decree of a new clawback tax mechanism for pharmaceuticals to help control consumption growth while generating additional revenues for the health care system, which is essential to achievement of the program's fiscal and general government arrears targets by November 30, 2011, and (iii) Approval by the cabinet and submission to parliament of comprehensive 
amendments to health system legislation by December 31, 2011. The naming of advisors is essential for the SOE reform and privatization process, as the privatizations will bring significant additional investment into the transport and energy sectors to boost growth, while significantly improving transparency and operational efficiency. The clawback tax and the amendments to the comprehensive health care legislation are crucial for tackling the fiscal problems stemming from the public healthcare system by both raising revenues and reducing incentives for higher pharmaceutical spending.

34. Program Modalities. Romania is not expected to face actual balance of payments financing needs in 2011 and 2012, and the Stand-By Arrangement, as well as financing commitments from the EU are expected to continue to be treated as precautionary. In the event of a shock scenario in the euro area periphery, staff analysis suggests that reserve buffers should be adequate to cover potential financing gaps arising from a direct liquidity shock to the banking system and indirect economy-wide shocks. However, risks have risen of a larger international financial shock which could lead to drawings under the Stand-By Arrangement.

35. Program risks. Romania's capacity to repay the Fund is expected to remain strong. Fund credit outstanding would peak in 2011 at 33.6 percent of gross reserves. Peak payments would be in 2013-14 at a still manageable 11.6 and 10.9 percent of gross reserves and around 8.2 and 7.2 percent of exports of goods and services. While this exposure remains large, servicing risks are mitigated by the relatively low level of public debt. Direct public indebtedness is expected to remain under 35 percent of GDP, with public external debt peaking at around 15 percent of GDP in 2012. Total external debt is projected to peak at end-2011 to 75.4 percent of GDP and decline thereafter. In addition, an update of the 2009 safeguards assessment found a robust safeguards framework at the NBR, while recommending measures to sustain NFA reporting standards and effective audit oversight, and enhance accounting disclosures.

36. Fund staff has continued to cooperate closely with the staff of the EC and the

WB. Fund, EC and the WB staff have consulted each other regularly regarding economic and policy developments in Romania, and EC and WB staff participated in Fund meetings with the authorities. The EC approved disbursal of the final tranche of its support program ( $€ 150$ million) in May and approved their new precautionary arrangement of $€ 1.4$ billion which parallels the new Fund SBA.

\section{StafF Appraisal}

37. Romania's economic growth continues, but the recovery is fragile and no effort should be spared in minimizing policy risks. While staff's baseline forecast remains favorable, the recent resurgence in international economic uncertainty could threaten Romania in several ways. Lower European growth could depress the heretofore booming export sector. Financial sector disruptions could spill over into the country via the largely 
foreign-owned banking sector. International financial market uncertainties could raise borrowing costs and threaten access to government financing and private investment resources. For this reason, it is more essential than ever that the authorities maintain their commitment to the policies contained in the Fund-supported program so as to minimize contagion risks. Strong fiscal financing buffers, financial sector buffers from tight prudential requirements, and foreign exchange buffers from high NBR reserves can act — together with an unwavering commitment to prudent fiscal and monetary policy — as a crucial line of defense against an uncertain international climate.

38. Fiscal performance in $\mathbf{2 0 1 1}$ has been excellent, and achievement of the year-end target is highly likely. The difficult fiscal measures undertaken in 2010 have borne fruit in a falling deficit and overperformance vis-à-vis the program targets in 2011. The authorities' commitment to continued reductions in public employment have been particularly successful in creating the needed fiscal space to gradually restore wages to remaining workers. However, chronic problems in health care spending must be decisively addressed. The unsustainable practice of recent years has been to budget at a level below that needed to cover the legal entitlements of the system, and then to try to paper over the gap with arrears and half-measures. In this context, the authorities' decision to implement a more comprehensive reform is welcome. Additional efforts are also needed to fully execute the 2011 capital budget, where the authorities consistently underperform, especially on EU-related investment spending.

\section{The medium-term fiscal outlook is favorable, but there are challenges in} reaching the EU 2012 deficit target. Pension, social benefits, and public wage reforms should produce significant additional savings in the coming years. If the health care problem is adequately dealt with, the authorities' medium-term fiscal objectives are well within reach. However, the 2012 deficit target agreed with the EU may prove difficult. Prudent expenditure policies already contemplated should yield a cash deficit of under 3 percent of GDP. But to reach the accrual deficit target of under 3 percent with the EU, the authorities will have to make provisions for the gap between accrual and cash accounting (traditionally around $1 / 2-3 / 4$ percent of GDP). In addition, Eurostat is expected to incorporate into the fiscal accounts a number of loss-making SOEs, which would require further fiscal adjustment of up to another $1 / 2-1$ percent of GDP. Arrears reduction should reduce the gap between cash and accrual accounting, but further measures would be required. SOE reform measures for those firms coming under the general government could also help. While there might be some room for reductions in capital spending, few other areas of quick expenditure cuts remain. New short-term revenue raising measures will also prove difficult, given the increases in excise, social contribution, and VAT rates already implemented in 2009-10.

\section{Implementation of planned structural reforms is essential if sustainable} economic growth is to be maintained. The stocktaking exercise recently completed has uncovered a larger number of enterprises with significantly higher losses and arrears than previously understood. This discovery has reinforced the need for action to restructure, privatize, or close these firms. The SOE reform agenda is very ambitious, both politically and 
technically, particular given upcoming elections in 2012. But from the standpoint of macroeconomic impact, an even more ambitious approach would have been preferable, as even the completion of all reforms under the program will still leave a large state-owned sector only partially adapted to the needs of a modern EU state.

\section{The authorities' strongly proactive stance in banking supervision has helped} forestall banking sector difficulties, but risks have risen sharply. With more than 80 percent of the banking system controlled by foreign banks (including several from the euro area periphery), Romania is particularly vulnerable to increasing banking sector uncertainties elsewhere in Europe. While significant capital and liquidity buffers exist in the system, the authorities should step-up efforts to ensure future stability. Enhanced monitoring of banking sector flows should be coupled with detailed contingency plans for any domestic banking problems, as well as possible contagion from the euro area. The authorities should continue to develop procedures to use their newly enhanced bank resolution powers so as to be fully prepared in the event a bank were to face problems. In this respect, the recent commitment to provide the legal mechanism for bridge banking activities is particularly welcome. The authorities also need to remain alert to any difficulties in small local banks.

\section{While the urgency of tightening monetary policy has eased due to the} exceptionally steep fall in inflation in the past few months, vigilance is still needed. It is still likely that the end-2011 inflation target will be missed, and the inflation consultation mechanism under the program may still be triggered in future reviews. Further expected hikes in administered prices, increasing inflation expectations, and recent depreciation pressures suggest that inflation risks remain. Staff continues to advise a tightening bias in monetary policy until the inflation path returns to the range consistent with the inflation target. The authorities have attempted to avoid excessive RON liquidity via foreign exchange intervention. While this is an admirable objective to reduce inflationary pressures, staff would advise minimizing exchange market interventions in favor of a reliance on open market operations so as to preserve an adequate cushion of NBR reserves given the heightened instability in international markets. The NBR should also avoid letting considerations of its own balance sheet unduly affect its choice of monetary policy instruments.

\section{On the basis of Romania's performance under the SBA, staff supports the} authorities' requests for completion of the second review under the new arrangement. Staff also recommends approval of the modification of program conditionality, as proposed in the attached Letter of Intent. 


\section{Box. The Stand-By Arrangement}

Access: SDR 3,090.6 million, 300 percent of quota.

Length: 24 months.

Phasing: SDR 60 million was made available upon Board approval of the arrangement on March 25, 2011, which became effective on March 31, 2011. The subsequent disbursement of SDR 430 million became available on June 27 with the completion of the first review.

SDR 430 million will be made available subject to the completion of this review. Six subsequent disbursements, totally SDR 2170.6 million, are contingent upon completion of the third to the eighth review.

Conditionality

- Quantitative Performance Criteria

A floor on the change in net foreign assets

$>$ A ceiling on central government and social security domestic arrears

$>$ A floor on the overall general government cash balance

$>$ A ceiling on general government guarantees

$>$ Non-accumulation of external debt arrears

- Quantitative Indicative Targets

$>$ A ceiling on general government current primary spending

$>$ A ceiling on local government domestic arrears

$>$ A floor on the operating balance and a ceiling on arrears of the key loss-making SOEs

- A consultation band around the 12-month rate of inflation of consumer prices

- Prior Action

$>$ Increase the gas price for non-residential customers by 8 percent, in order to further align with CUG formula. 


\section{Box. The Stand-By Arrangement (continued)}

\section{- $\quad$ Structural Benchmarks}

Undertake SOE reforms, including (i) Appointment of legal advisors for privatization of CFR Marfa, TAROM, Transelectrica, Transgaz, and Romgaz; (ii) Preparation of action plans for the remaining SOEs of the central government; (iii) Design mechanisms to facilitate restructuring and securitizing SOE arrears. July 15, 2011.

$>$ Eliminate by government ordinance the legal basis of stimulente funds, effective January 1, 2012. August 31, 2011.

Completion of a comprehensive review of the existing investment portfolio, which will prioritize and evaluate existing projects to focus on those where funding can be fully secured, examine the viability of old projects, with low priority and unviable ones discontinued, and production of a final report and an action plan. September 30, 2011.

$>$ Selection of advisors for SOE reform (i) Select transaction advisors for group1 and (ii) legal advisors for group 2. October 31, 2011(proposed).

$>$ Amend legislation to allow the use of the deposit guarantee fund resources to facilitate bank restructuring, including purchase and assumption transactions. September 30, 2011 (Reset from November 30, 2011).

Approve legislation to improve governance of SOEs. October 31, 2011(Reset from August 31, 2011).

$>$ Impose a revised clawback tax on the pharmaceuticals based on the growth in their costs or above a pre-determined threshold. November 30, 2011 (proposed).

Introduction of a simplified taxation system for smaller taxpayers under the threshold with help from the IMF and EC, while requesting a shift in the VAT mandatory threshold from the EU Council of Ministers to $€ 50,000$. December 31, 2011.

Prepare comprehensive amendments to the health care legislation to address the persistent budgetary shortfalls and to ensure high quality health care services.

December 31, 2011(proposed). 
Figure 1. Romania: Real Sector, 2007-11
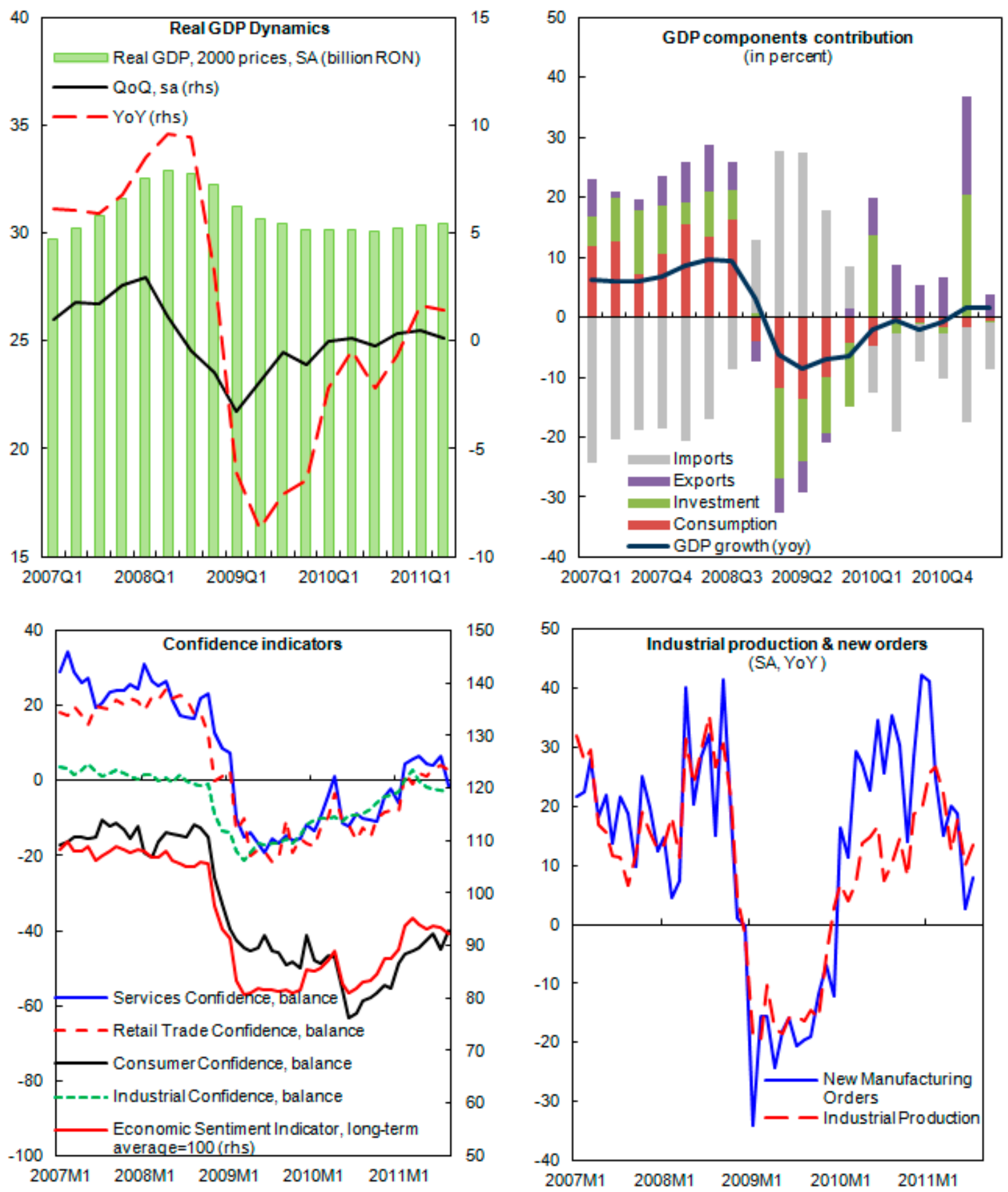

Source: Haver. 
Figure 2. Romania: External Sector, 2007-11.
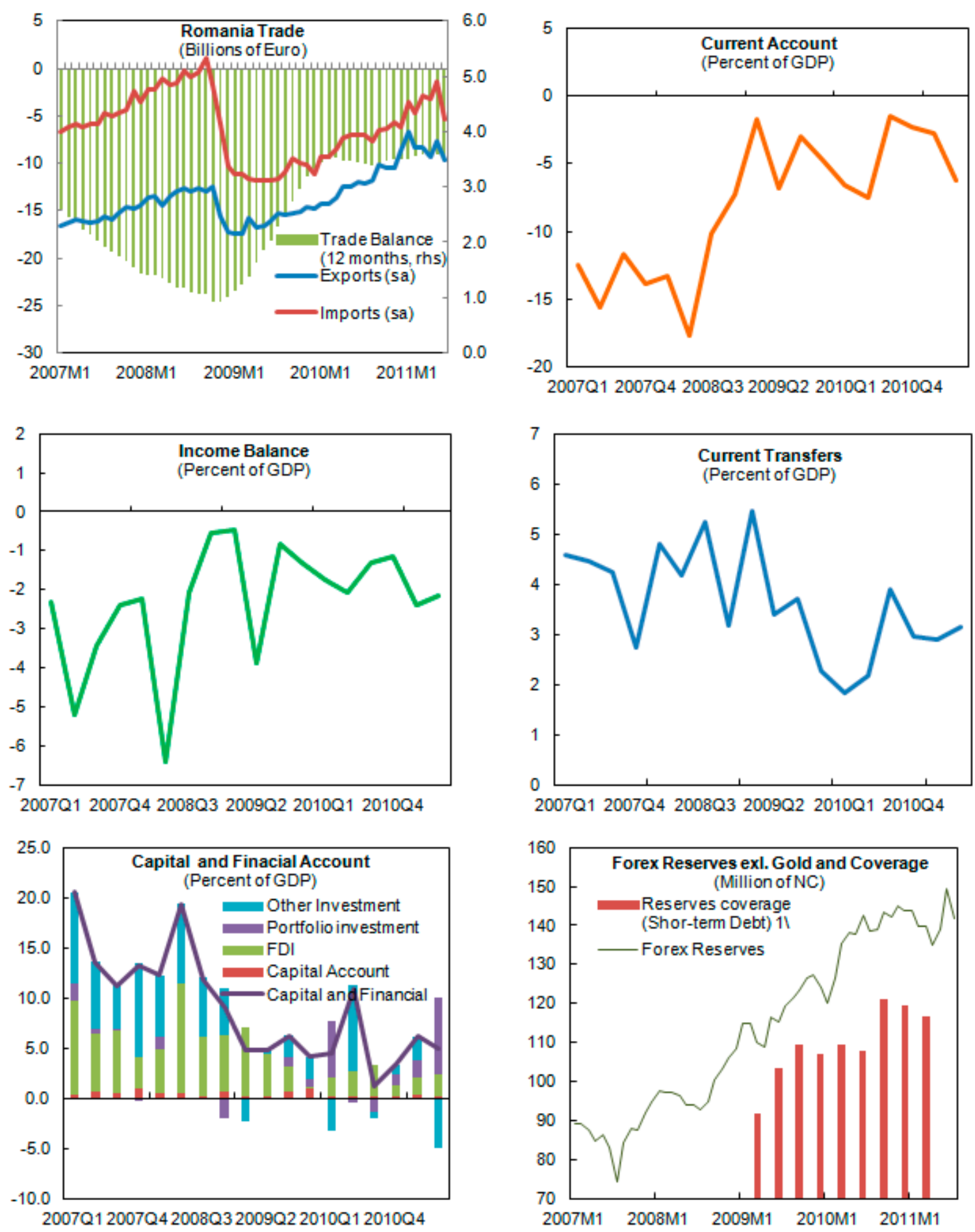

Source: Haver.

$1 \backslash 2011 \mathrm{Q} 1$ is a projection for year 2011. 
Figure 3. Romania: Labor Sector, 2007-11
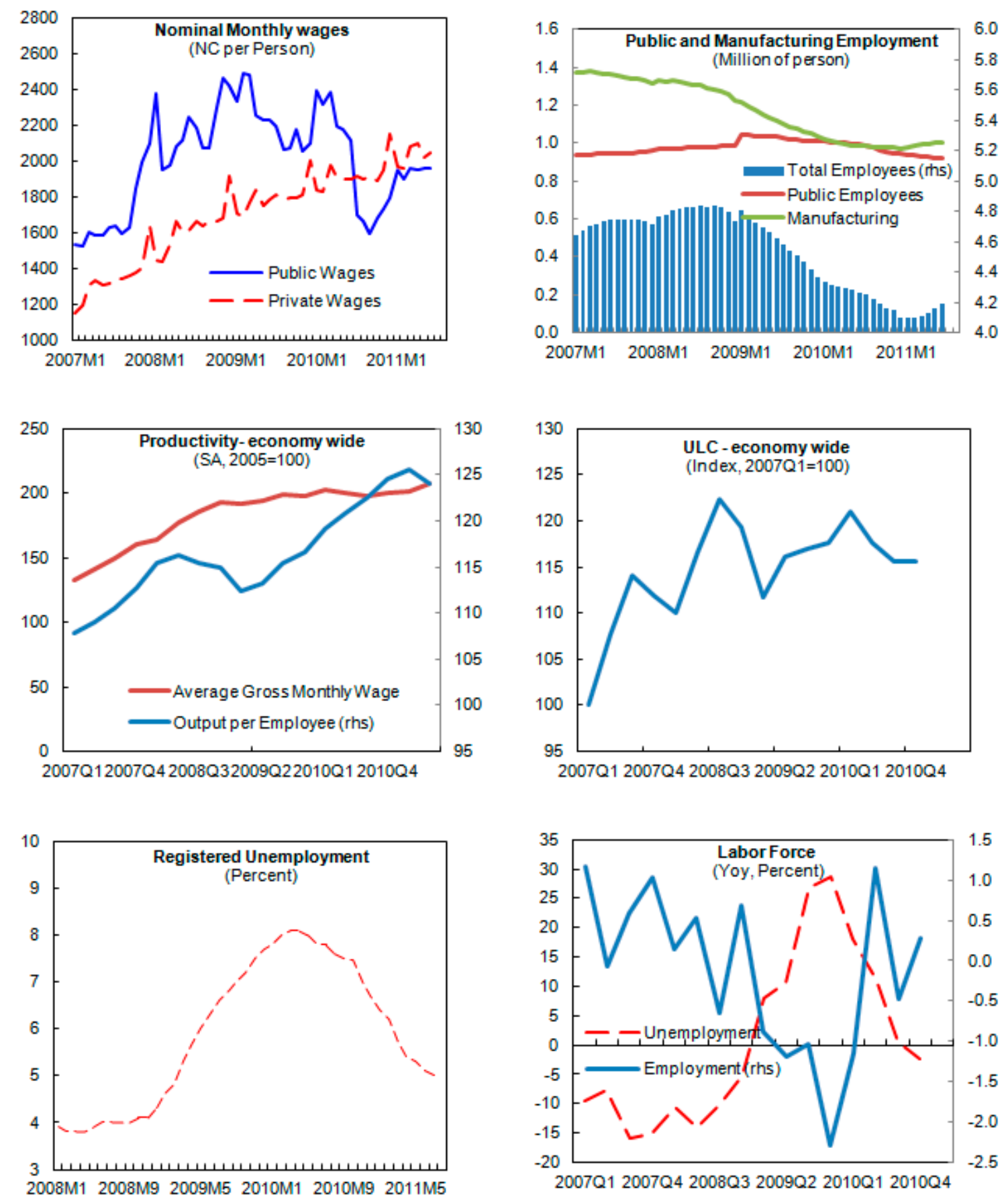

Source: Haver. 
Figure 4. Romania: Monetary Sector, 2005-11

(Percent)
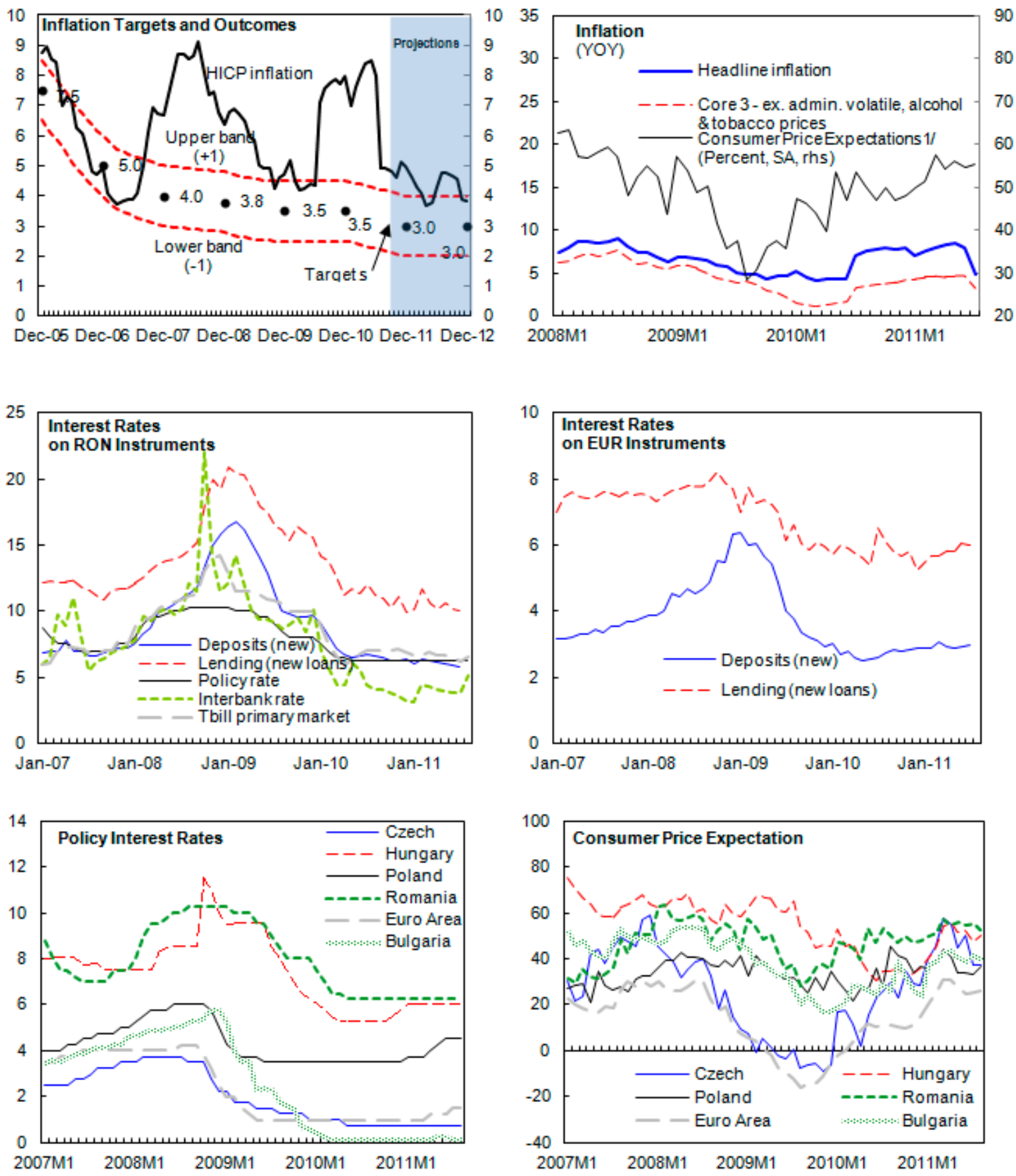

Source: Haver; Romania National Bank; Consensus Forecast; IMF staff estimates. 1/ Price Trends over next 12 Months. 
Figure 5. Romania: Fiscal Operations, 2005-12

(Percent of GDP)
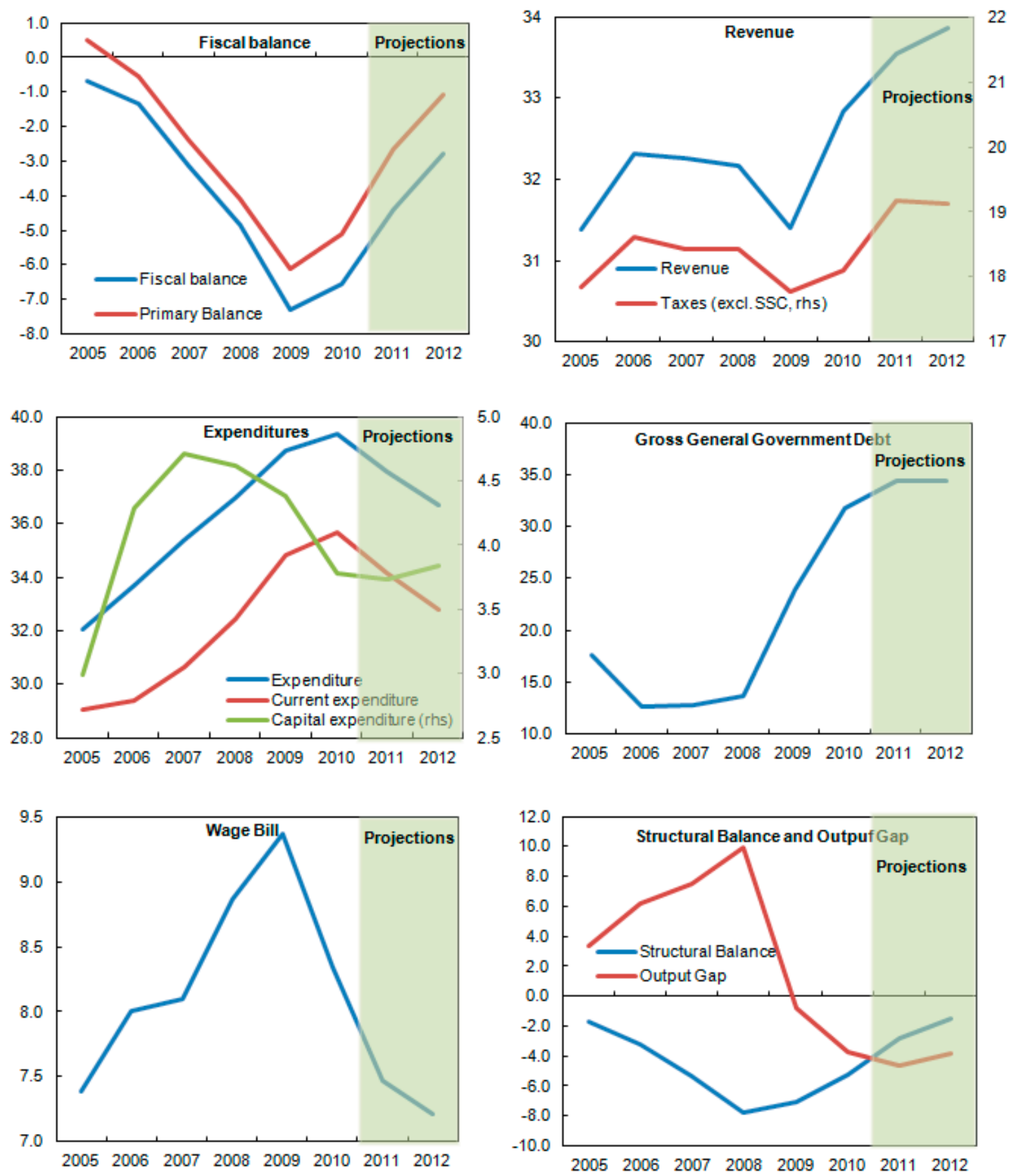

Source: Romania National Authorities. 
Figu re 6. Romania: Financial Sector, 2007-11
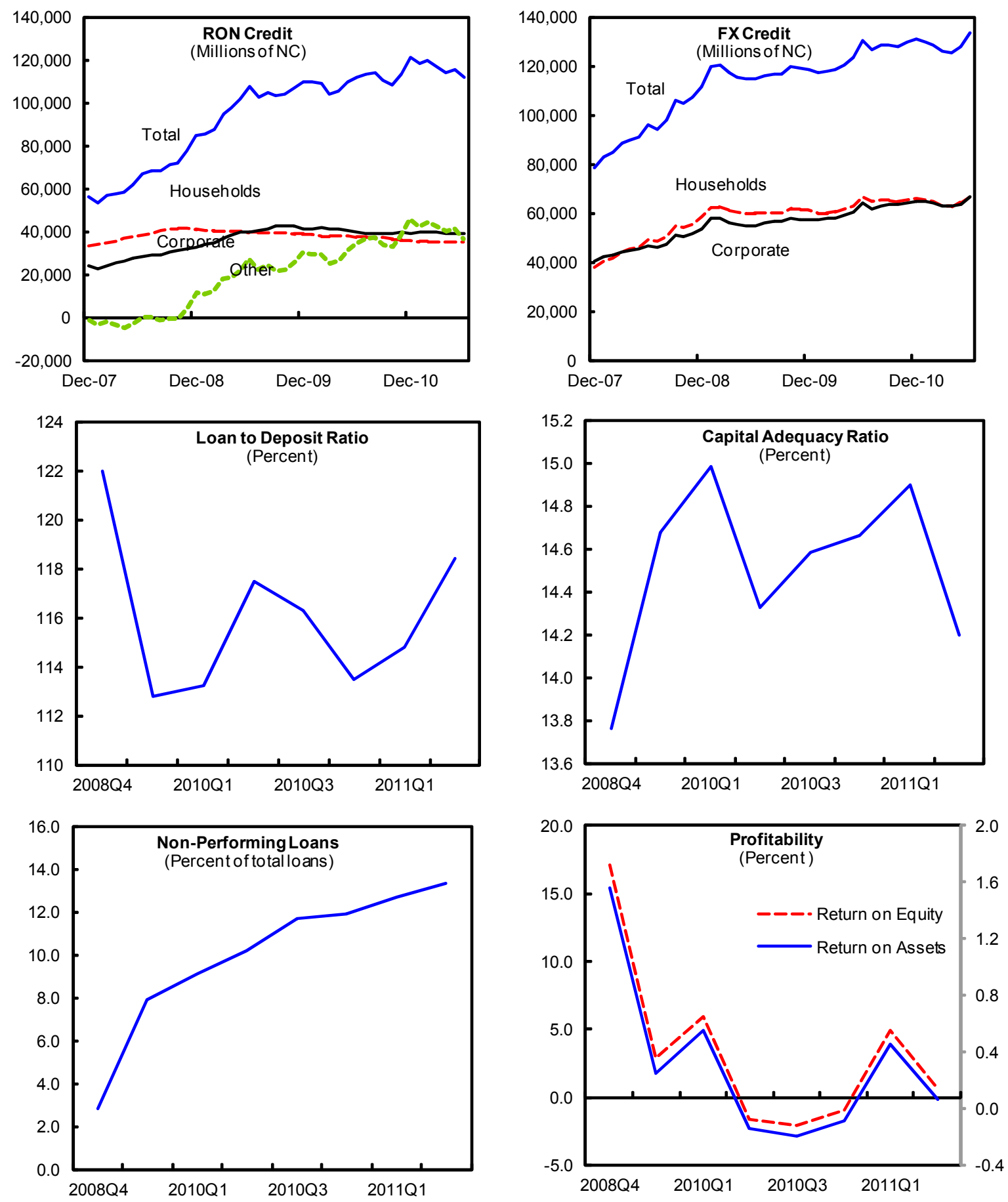

Source: Dxtime; Romania National Bank. 
Figure 7. Romania: Financial Developments
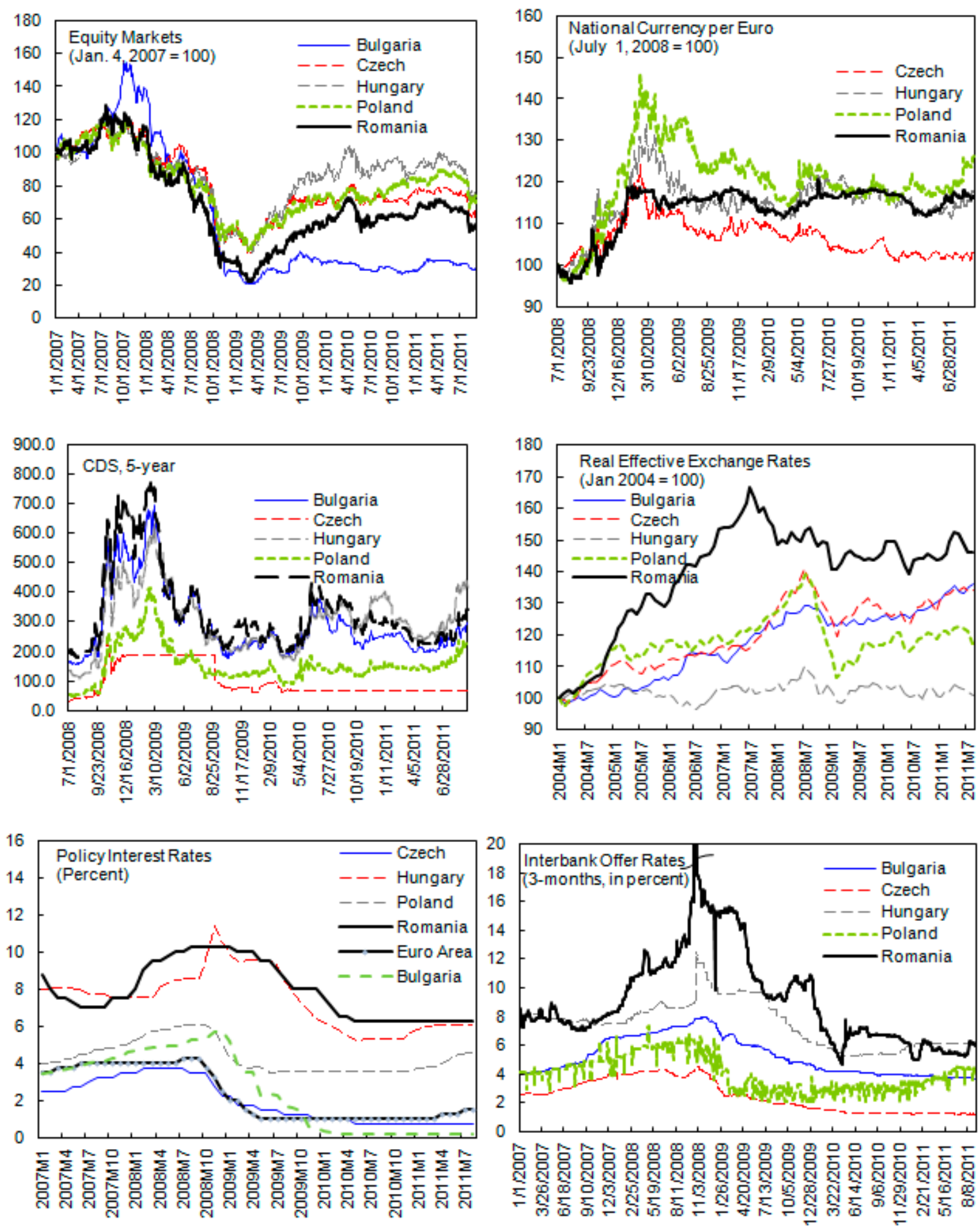

Source: Bloomberg; Haver. 
Figure 8. Romania: Public Debt Sustainability: Bound Tests 1/ (Public debt in percent of GDP)
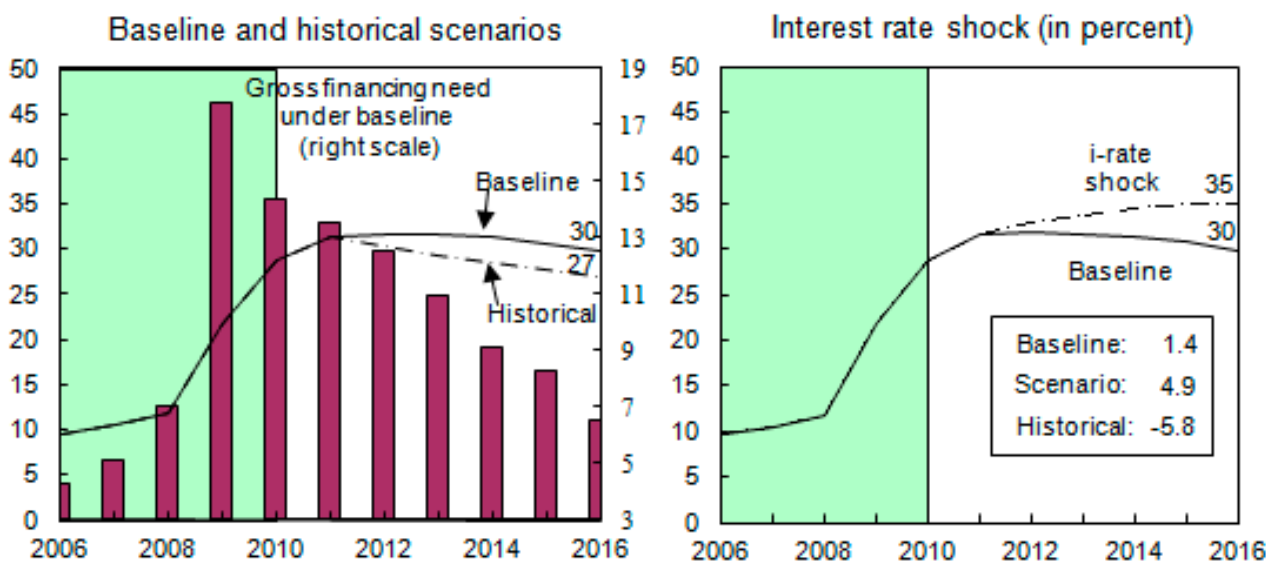

Growth shock

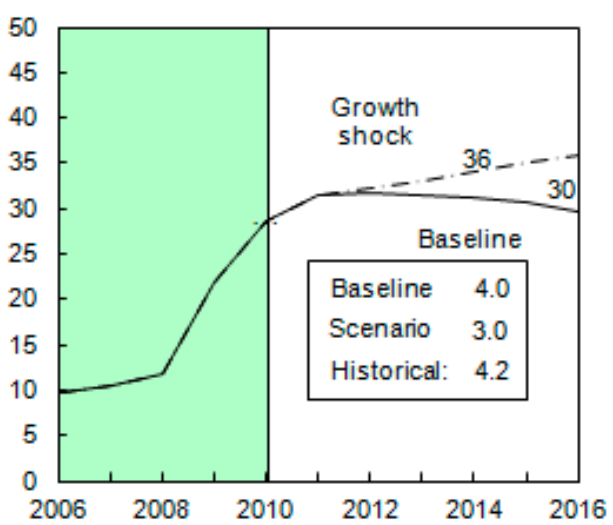

Primary balance shock (in percent of GDP) and no policy change scenario (constant primary

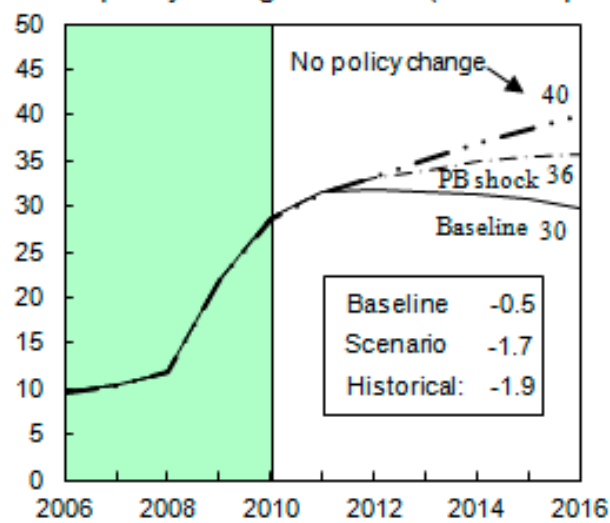

Combined shock $2 /$

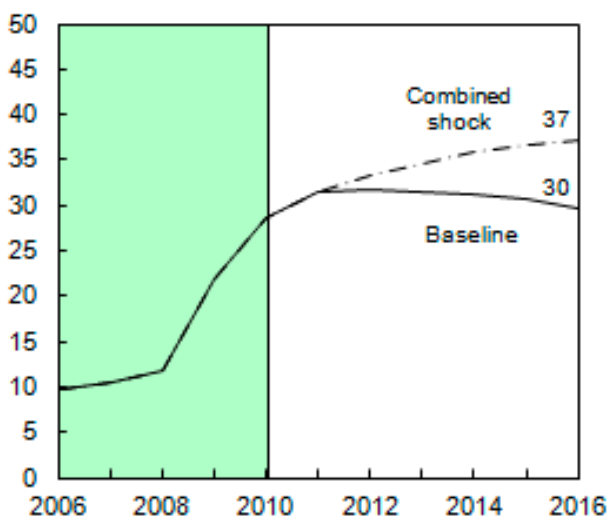

Real depreciation and contingent liabilities shocks 3/

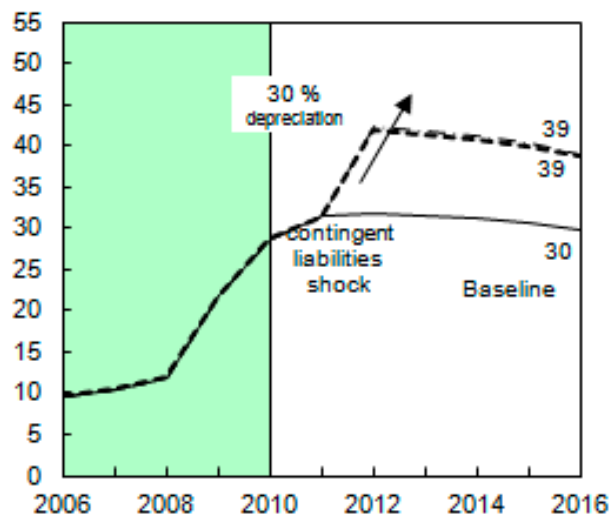

Sources: Intemational Monetary Fund, country desk data, and staff estimates.

1/Shaded areas repres ent actual data. Individual shocks are permanent one-half standard deviation shocks.

Figures in the boxes represent average projections for the respective variables in the baseline and scenario being presented. Ten-year historical average for the variable is also shown.

$2 /$ Permanent $1 / 4$ standard deviation shocks ap plied to real interest rate, growth rate, and primary balance.

$3 /$ One-time real depreciation of 30 percent and 10 percent of GDP shock to contingent liabilities occur in 2010 ,

with real depreciation defined as nominal depreciation (measured by percentage fall in dollar value of local

currency) minus domestic inflation (based on GDP deflator). 
Figure 9. Romania: External Debt Sustainability: Bound Tests 1/ (External debt in percent of GDP)

Baseline and historical scenarios

Interest rate shock (in percent)
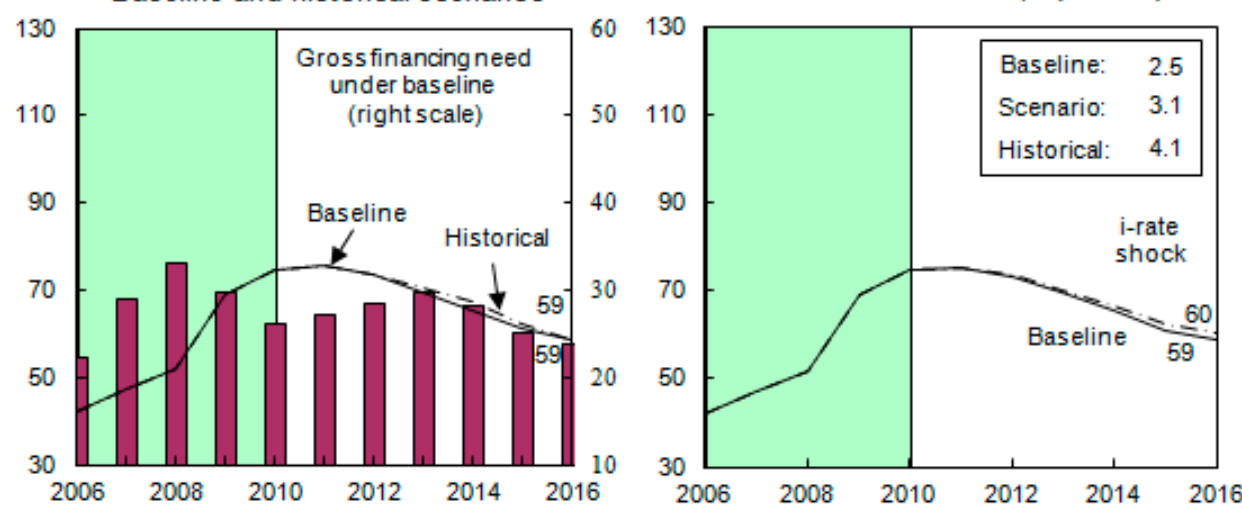

Growth shock (in percent per year)

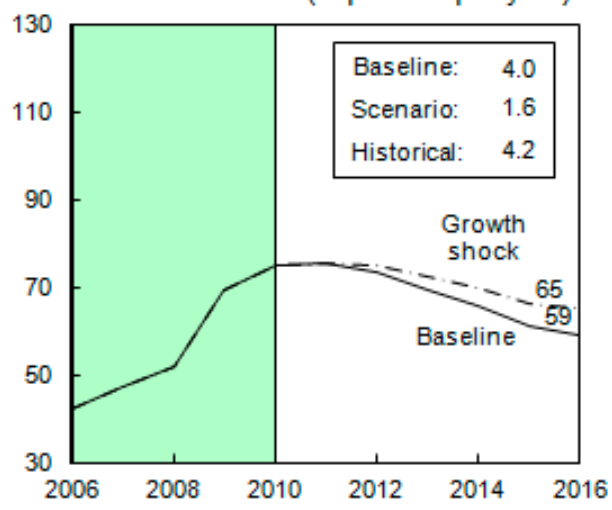

Non-interest current account shock

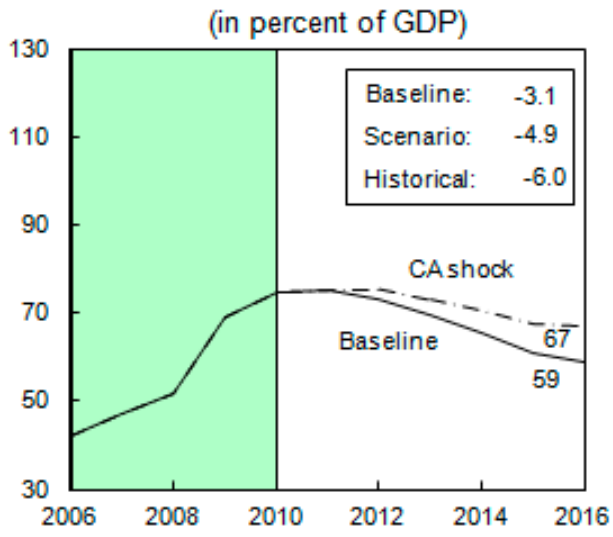

Combined shock $2 /$

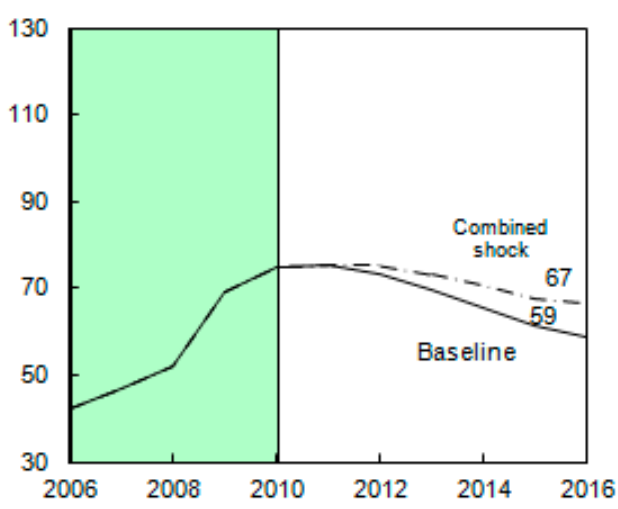

Real depreciation shock $3 /$

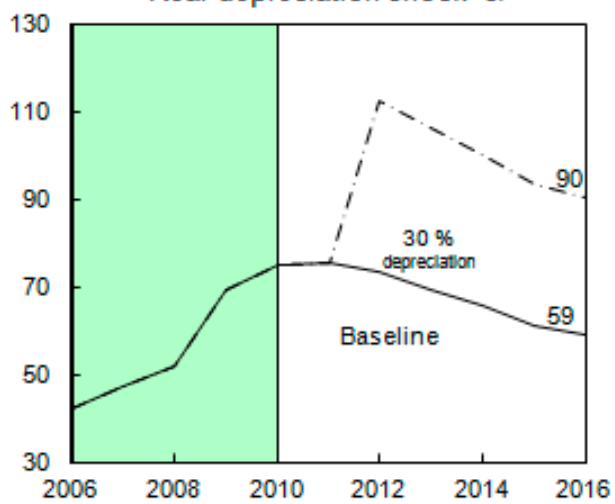

Sources: International Monetary Fund, Country desk data, and staff estimates.

1/Shaded areas represent actual data. Individual shocks are permanent one-half standard deviation shocks. Figures in the boxes represent average projections for the respective variables in the baseline and scenario being presented. Ten-year historical average for the variable is also shown. $2 /$ Permanent $1 / 4$ standard deviation shocks applied to real interest rate, growth rate, and current account balance.

3/One-time real depreciation of 30 percent occurs in 2010 . 
Table 1. Romania: Quantitative Program Targets

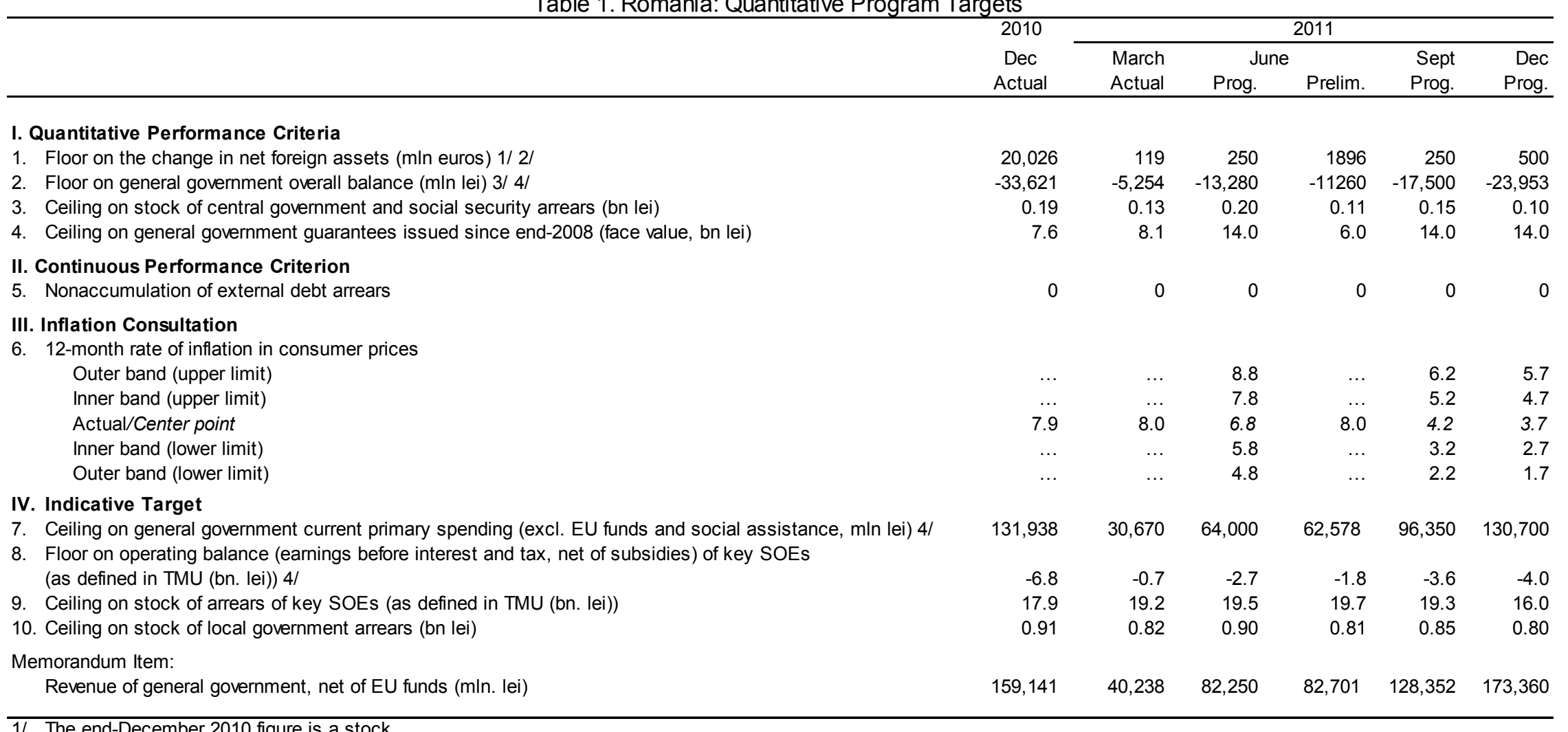

2010 figure is a stock.

2/ Cumulative flows relative to end-December 2010 stock.

3/ Cumulative figure during calendar year (e.g. March 2011 figure is cumulative from January 1, 2011)

4/ Adjusted performance criterion for end-June. 
Table 2. Romania: Performance for Second Review and Proposed New Conditionality

Measure $\quad$ Comment Date

Prior Actions

1. Increase the gas price for non-residential customers, in order to further align with CUG formula, by 8 percent.

At least 5 working days before the

Quantitative performance criteria

1. Floor on net foreign assets

2. Floor on general government overall balance

3. Ceiling on central government and social security domestic arrears

4. Ceiling on general government guarantees

5. Non-accumulation of external debt arrears

\section{Quantitative Indicative Target}

1. Ceiling on general government current primary spending

2. Floor on operating balance of key SOEs

3. Ceiling on stock of arrears of key SOEs

4. Ceiling on stock of local government arrears

\section{Inflation consultation band}

Inner band

Outer band

\section{Structural benchmarks}

1. Undertake SOE reforms, including (i) Appointment of legal advisors for privatization of CFR Marfa, TAROM, Transelectrica, Transgaz, and Romgaz; (ii) Preparation of action plans for the remaining SOEs of the central government; (iii) Design mechanisms to facilitate restructuring and securitizing SOE arrears.

2. Approve legislation to improve governance of SOEs.

3. Eliminate by government ordinance the legal basis of all the stimulente funds, effective January 1, 2012.

4. Completion of a comprehensive review of the existing investment portfolio, which will prioritize and evaluate existing projects to focus on those where funding can be fully secured, examine the viability of old projects, with low Sept. 30, 2011 priority and unviable ones discontinued, and production of a final report and an action plan.

5. Amend legislation to allow the use of the deposit guarantee fund resources to facilitate bank restructuring, including purchase and assumption transactions.

6. Introduction of a simplified taxation system for smaller taxpayers under the threshold with help from the IMF and EC, while requesting a shift in the VAT mandatory threshold from the EU Council of Ministers to $€ 50,000$.

Nov. 30, 2011

New structural benchmark

1. Selection of advisors for SOE reform: (i) select transaction advisors for group 1 and (ii) legal advisors for group 2

2. Impose a revised clawback tax on the pharmaceuticals based on the growth in their costs or above a predetermined threshold.

3. Prepare comprehensive amendments to the health care legislation to address the persistent budgetary shortfalls and to ensure high quality health care services. 
Table 3. Romania: Selected Economic and Social Indicators, 2007-12

\begin{tabular}{|c|c|c|c|c|c|c|c|}
\hline & \multirow[t]{2}{*}{2007} & \multirow[t]{2}{*}{2008} & \multirow[t]{2}{*}{2009} & \multirow{2}{*}{2010} & \multicolumn{2}{|c|}{2011} & \multirow{2}{*}{$\begin{array}{r}2012 \\
\text { Proj }\end{array}$} \\
\hline & & & & & Rev. Prog. & Proj. & \\
\hline \multicolumn{3}{|l|}{ Output and prices } & \multicolumn{4}{|c|}{ (Annual percentage change) } & \\
\hline Real GDP & 6.3 & 7.3 & -7.1 & -1.3 & 1.5 & 1.5 & 3.5 \\
\hline \multicolumn{8}{|l|}{ Contributions to GDP growth } \\
\hline Domestic demand & 15.9 & 8.3 & -14.6 & -1.0 & 0.9 & 0.3 & 3.6 \\
\hline Net exports & -9.6 & -1.0 & 7.5 & -0.2 & 0.6 & 1.2 & -0.1 \\
\hline Consumer price index (CPI, average) & 4.8 & 7.8 & 5.6 & 6.1 & 6.8 & 6.4 & 4.3 \\
\hline Consumer price index (CPI, end of period) & 6.7 & 6.4 & 4.7 & 8.0 & 5.7 & 5.0 & 3.8 \\
\hline Producer price index (end of period) & 7.6 & 15.3 & 1.9 & 6.3 & $\ldots$ & $\ldots$ & $\ldots$ \\
\hline Unemployment rate (registered, average) & 4.3 & 4.0 & 6.3 & 7.6 & 6.1 & 5.0 & 4.8 \\
\hline Unemployment rate (LFS, average) & 6.4 & 5.8 & 6.9 & 7.3 & & & $\ldots$ \\
\hline Nominal wages & 22.7 & 23.7 & 8.5 & 2.4 & 5.7 & 5.7 & 7.0 \\
\hline \multicolumn{3}{|l|}{ Saving and Investment } & \multicolumn{4}{|c|}{ (In percent of GDP) } & \\
\hline Gross domestic investment & 31.0 & 31.3 & 25.3 & 26.5 & 26.0 & 27.3 & 27.4 \\
\hline Gross national savings & 17.6 & 19.7 & 21.1 & 22.2 & 21.3 & 22.9 & 22.8 \\
\hline \multicolumn{8}{|l|}{ General government finances } \\
\hline Revenue & 32.3 & 32.2 & 31.4 & 32.8 & 33.1 & 33.5 & 33.9 \\
\hline Expenditure & 35.4 & 37.0 & 38.7 & 39.4 & 37.5 & 37.9 & 36.7 \\
\hline Fiscal balance & -3.1 & -4.8 & -7.3 & -6.5 & -4.4 & -4.4 & -2.8 \\
\hline Privatization proceeds $1 /$ & 0.1 & 0.1 & 0.0 & 0.1 & 0.1 & 0.1 & 0.1 \\
\hline External financing & 0.1 & 0.4 & 2.9 & 2.9 & 2.4 & 2.2 & 1.4 \\
\hline Domestic financing & 2.9 & 4.3 & 4.4 & 3.6 & 1.9 & 2.2 & 1.3 \\
\hline Structural fiscal balance 2/ & -5.8 & -8.5 & -7.0 & -5.1 & -2.7 & -2.6 & -1.4 \\
\hline Gross public debt (direct debt only) & 10.4 & 11.8 & 21.8 & 28.7 & 31.4 & 31.5 & 31.8 \\
\hline \multicolumn{3}{|l|}{ Money and credit } & \multicolumn{4}{|c|}{ (Annual percentage change) } & \\
\hline Broad money (M3) & 33.7 & 17.5 & 9.0 & 6.9 & 10.2 & 8.3 & 11.1 \\
\hline Credit to private sector & 60.4 & 33.7 & 0.9 & 4.7 & 7.0 & 4.1 & 7.4 \\
\hline \multicolumn{3}{|l|}{ Interest rates, eop } & \multicolumn{4}{|c|}{ (In percent) } & \\
\hline Euribor, six-months & 4.8 & 3.5 & 4.5 & 1.2 & $\cdots$ & $\cdots$ & ... \\
\hline NBR policy rate & 7.5 & 10.3 & 8.0 & 6.3 & $\ldots$ & $\ldots$ & $\ldots$ \\
\hline NBR lending rate (Lombard) & 12.0 & 14.3 & 12.0 & 10.3 & $\cdots$ & $\ldots$ & $\ldots$ \\
\hline Interbank offer rate ( 1 week) & 7.1 & 12.7 & 10.7 & 3.6 & $\cdots$ & $\ldots$ & $\ldots$ \\
\hline \multirow{2}{*}{\multicolumn{3}{|c|}{ Balance of payments }} & \multicolumn{3}{|c|}{ (In percent of GDP) } & & \\
\hline Current account balance & & -11.6 & -4.2 & -4.3 & -4.7 & -4.5 & -4.6 \\
\hline Merchandise trade balance & -14.3 & -13.7 & -5.8 & -4.9 & -4.5 & -4.0 & -4.1 \\
\hline Capital and financial account balance & 17.6 & 12.7 & -2.5 & 1.2 & 3.5 & 4.6 & 7.6 \\
\hline Foreign direct investment balance & 5.7 & 6.7 & 3.0 & 2.2 & 3.1 & 2.2 & 2.2 \\
\hline International investment position & -43.5 & -49.4 & -62.7 & -63.9 & -62.6 & -75.7 & -70.1 \\
\hline Gross official reserves & 21.8 & 20.2 & 26.2 & 29.5 & 29.2 & 30.4 & 30.2 \\
\hline Gross external debt & 47.1 & 51.8 & 69.0 & 74.7 & 74.0 & 75.4 & 73.3 \\
\hline \multicolumn{8}{|l|}{ Exchange rates } \\
\hline Lei per euro (end of period) & 3.5 & 4.0 & 4.2 & 4.3 & $\ldots$ & $\ldots$ & $\ldots$ \\
\hline Lei per euro (average) & 3.3 & 3.7 & 4.2 & 4.2 & $\ldots$ & $\ldots$ & $\ldots$ \\
\hline Real effective exchange rate & & & & & $\ldots$ & $\ldots$ & $\ldots$ \\
\hline CPI based (percentage change) & 8.5 & -5.0 & -7.6 & 2.0 & $\ldots$ & $\ldots$ & $\ldots$ \\
\hline GDP deflator based (percentage change) & 17.4 & 1.6 & -8.9 & 0.4 & $\ldots$ & $\ldots$ & $\ldots$ \\
\hline \multicolumn{8}{|l|}{ Memorandum Items: } \\
\hline Nominal GDP (in bn RON) & 416.0 & 514.7 & 498.0 & 513.6 & 542.9 & 543.0 & 588.9 \\
\hline $\begin{array}{l}\text { Social and Other Indicators } \\
\text { GDP per capita (current US\$, 2009): } \$ 7,500 \text {; } \\
\text { Poverty rate: } 5.7 \%(2008)\end{array}$ & GDP per & oita, PP & (current i & rnational & \$, 2009): $\$$ & 198 & \\
\hline
\end{tabular}


Table 4. Romania: Macroeconomic Framework, Current Policies, 2008-16

\begin{tabular}{|c|c|c|c|c|c|c|c|c|c|c|}
\hline & \multirow[t]{2}{*}{2008} & \multirow[t]{2}{*}{2009} & \multirow{2}{*}{2010} & \multicolumn{2}{|c|}{2011} & \multirow{2}{*}{$\begin{array}{c}2012 \\
\text { Proj. }\end{array}$} & \multirow{2}{*}{$\begin{array}{c}2013 \\
\text { Proj. }\end{array}$} & \multirow{2}{*}{$\begin{array}{l}2014 \\
\text { Proj. }\end{array}$} & \multirow{2}{*}{$\begin{array}{l}2015 \\
\text { Proj. }\end{array}$} & \multirow{2}{*}{$\begin{array}{r}2016 \\
\text { Proj. }\end{array}$} \\
\hline & & & & Rev. Prog. & Proj. & & & & & \\
\hline \multicolumn{11}{|l|}{ GDP and prices (annual percent change) } \\
\hline Real GDP & 7.3 & -7.1 & -1.3 & 1.5 & 1.5 & 3.5 & 3.8 & 4.3 & 4.0 & 4.1 \\
\hline Real domestic demand & 7.3 & -12.9 & -1.0 & 0.9 & 0.3 & 3.6 & 3.6 & 4.3 & 4.4 & 4.2 \\
\hline Consumption & 8.7 & -7.8 & -2.1 & 0.1 & -1.0 & 3.3 & 3.5 & 4.2 & 4.7 & 4.5 \\
\hline Investment & 3.7 & -26.2 & 2.7 & 3.3 & 4.1 & 4.3 & 4.0 & 4.5 & 3.8 & 3.4 \\
\hline Exports & 8.3 & -5.3 & 13.1 & 7.9 & 16.0 & 7.3 & 8.1 & 8.3 & 8.2 & 8.3 \\
\hline Imports & 7.9 & -20.9 & 11.6 & 5.5 & 11.0 & 6.6 & 7.2 & 7.9 & 8.7 & 8.1 \\
\hline Consumer price index (CPI, average) & 7.8 & 5.6 & 6.1 & 6.8 & 6.4 & 4.3 & 3.2 & 3.0 & 3.0 & 3.0 \\
\hline Consumer price index (CPI, end of period) & 6.4 & 4.7 & 8.0 & 5.7 & 5.0 & 3.8 & 3.0 & 3.0 & 3.0 & 3.0 \\
\hline \multicolumn{11}{|l|}{ Saving and investment (in percent of GDP) } \\
\hline Gross national saving & 19.7 & 21.1 & 22.2 & 21.3 & 22.9 & 22.8 & 24.3 & 25.0 & 25.5 & 25.6 \\
\hline Government & 1.5 & -2.0 & 0.8 & 2.8 & 2.8 & 4.5 & 5.1 & 5.4 & 5.8 & 6.1 \\
\hline Private & 18.2 & 23.2 & 21.3 & 18.4 & 20.1 & 18.3 & 19.2 & 19.6 & 19.7 & 19.5 \\
\hline Gross domestic investment & 31.3 & 25.3 & 26.5 & 26.0 & 27.3 & 27.4 & 29.0 & 29.7 & 30.1 & 30.3 \\
\hline Government & 6.3 & 5.3 & 7.4 & 7.1 & 7.2 & 7.3 & 7.6 & 7.6 & 7.6 & 7.6 \\
\hline Private & 25.0 & 20.0 & 19.1 & 18.9 & 20.2 & 20.1 & 21.4 & 22.1 & 22.5 & 22.8 \\
\hline \multicolumn{11}{|l|}{ General government (in percent of GDP) } \\
\hline Revenue & 32.2 & 31.4 & 32.8 & 33.1 & 33.5 & 33.9 & 34.2 & 34.4 & 34.5 & 34.7 \\
\hline Tax revenue & 27.9 & 27.4 & 27.0 & 27.9 & 28.2 & 28.1 & 28.1 & 28.2 & 28.3 & 28.4 \\
\hline Non-Tax revenue & 3.1 & 2.9 & 3.9 & 3.5 & 3.6 & 3.3 & 3.2 & 3.2 & 3.3 & 3.3 \\
\hline Grants & 0.9 & 1.0 & 1.8 & 1.6 & 1.6 & 2.4 & 2.8 & 2.8 & 2.8 & 2.8 \\
\hline Expenditure & 37.0 & 38.7 & 39.4 & 37.5 & 37.9 & 36.7 & 36.6 & 36.6 & 36.3 & 36.1 \\
\hline Fiscal balance & -4.8 & -7.3 & -6.5 & -4.4 & -4.4 & -2.8 & -2.4 & -2.2 & -1.8 & -1.4 \\
\hline Structural fiscal balance $1 /$ & -8.5 & -7.0 & -5.1 & -2.7 & -2.6 & -1.4 & -1.3 & -1.5 & -1.4 & -1.2 \\
\hline Gross public debt (direct debt only) & 11.8 & 21.8 & 28.7 & 31.4 & 31.5 & 31.8 & 31.6 & 31.3 & 30.7 & 29.7 \\
\hline \multicolumn{11}{|l|}{ Monetary aggregates (annual percent change) } \\
\hline Broad money & 17.5 & 9.0 & 6.9 & 10.2 & 8.3 & 11.1 & 11.8 & 12.5 & 12.7 & 12.9 \\
\hline Domestic credit & 33.7 & 0.9 & 4.7 & 7.0 & 4.1 & 7.4 & 10.7 & 11.9 & 13.8 & 10.1 \\
\hline \multicolumn{11}{|l|}{ Balance of payments (in percent of GDP) } \\
\hline Current account & -11.6 & -4.2 & -4.3 & -4.7 & -4.5 & -4.6 & -4.7 & -4.7 & -4.7 & -4.7 \\
\hline Trade balance & -13.7 & -5.8 & -4.9 & -4.5 & -4.0 & -4.1 & -3.8 & -3.9 & -3.9 & -3.7 \\
\hline Services balance & 0.5 & -0.2 & -0.6 & -0.4 & -0.4 & -0.5 & -0.4 & -0.4 & -0.4 & -0.4 \\
\hline Income balance & -2.7 & -1.6 & -1.6 & -2.4 & -2.5 & -2.5 & -2.7 & -2.8 & -2.9 & -2.9 \\
\hline Transfers balance & 4.3 & 3.5 & 2.8 & 2.6 & 2.4 & 2.4 & 2.3 & 2.4 & 2.6 & 2.3 \\
\hline Capital and financial account balance & 12.8 & -1.9 & 1.2 & 3.5 & 4.6 & 7.6 & 8.0 & 7.7 & 4.9 & 5.2 \\
\hline Foreign direct investment, balance & 6.7 & 3.0 & 2.2 & 3.1 & 2.2 & 2.2 & 2.2 & 2.2 & 2.2 & 2.2 \\
\hline \multicolumn{11}{|l|}{ Memorandum items: } \\
\hline Gross international reserves (in billions of euros) & 28.3 & 30.9 & 36.0 & 38.4 & 39.8 & 43.0 & 43.6 & 44.1 & 43.1 & 44.3 \\
\hline Gross international reserves (in months of next year's imports) & 7.8 & 7.4 & 7.6 & 7.5 & 7.7 & 7.6 & 7.1 & 6.5 & 5.9 & 5.9 \\
\hline International investment position (in percent of GDP) & -49.4 & -62.7 & -63.9 & -62.6 & -75.7 & -70.1 & -70.7 & -70.3 & -74.2 & -69.2 \\
\hline Real effective exchange rate, CPI based & -5.0 & -7.6 & 2.0 & 5.5 & 4.2 & 0.1 & 2.7 & 3.2 & 2.4 & 2.1 \\
\hline External debt (in percent of GDP) & 51.8 & 69.0 & 74.7 & 74.0 & 75.4 & 73.3 & 69.4 & 65.5 & 61.1 & 58.7 \\
\hline Short-term external debt (in percent of GDP) & 14.7 & 13.1 & 15.3 & 14.9 & 15.3 & 15.0 & 14.6 & 14.1 & 13.8 & 13.4 \\
\hline Terms of trade (percent change) & 3.1 & 0.2 & 2.5 & -0.7 & -3.0 & -0.3 & -0.7 & -1.1 & -0.2 & -0.2 \\
\hline Nominal GDP (in millions of lei) & 514,700 & 498,008 & 513,641 & 542,920 & 543,040 & 588,940 & 640,045 & 692,543 & 750,885 & 814,185 \\
\hline Nominal GDP (in millions of Euros) & 139,666 & 117,558 & 122,062 & 131,329 & 131,001 & 142,458 & 156,341 & 172,176 & 189,671 & 208,563 \\
\hline Output Gap & 10.0 & -0.8 & -3.7 & -4.6 & -4.7 & -3.8 & -3.0 & -1.9 & -1.2 & -0.7 \\
\hline
\end{tabular}

Sources: Romanian authorities; and Fund staff estimates and projections.

1/ Actual fiscal balance adjusted for the automatic effects of internal imbalance (output gap) and external imbalance (absorption gap)

on the fiscal position. 
Table 5. Romania: Balance of Payments, 2008-16 (In billions of euros, unless otherwise indicated)

\begin{tabular}{|c|c|c|c|c|c|c|c|c|c|c|}
\hline & 2008 & 2009 & 2010 & 201 & & 2012 & 2013 & 2014 & 2015 & 2016 \\
\hline & Act & Act & Act & Prog & Proj. & Proj. & Proj. & Proj. & Proj. & Proj. \\
\hline Current account balance & -16.2 & -4.9 & -5.2 & -6.4 & -5.9 & -6.6 & -7.3 & -8.1 & -8.8 & -9.8 \\
\hline Merchandise trade balance & -19.1 & -6.9 & -6.0 & -6.4 & -5.2 & -5.8 & -5.9 & -6.7 & -7.4 & -7.8 \\
\hline Exports (f.o.b.) & 33.7 & 29.1 & 37.3 & 41.1 & 43.6 & 47.5 & 52.1 & 56.8 & 62.1 & 68.0 \\
\hline Imports (f.o.b.) & 52.8 & 36.0 & 43.2 & 47.5 & 48.8 & 53.3 & 58.0 & 63.5 & 69.5 & 75.8 \\
\hline Services balance & 0.7 & -0.3 & -0.7 & -0.8 & -0.6 & -0.7 & -0.7 & -0.8 & -0.8 & -0.9 \\
\hline Exports of non-factor services & 8.8 & 7.1 & 6.4 & 7.0 & 7.4 & 8.1 & 8.9 & 9.7 & 10.6 & 11.6 \\
\hline Imports of non-factor services & 8.1 & 7.4 & 7.1 & 7.8 & 8.0 & 8.7 & 9.5 & 10.4 & 11.4 & 12.4 \\
\hline Income balance & -3.7 & -1.9 & -2.0 & -2.1 & -3.3 & -3.6 & -4.3 & -4.8 & -5.5 & -6.0 \\
\hline Receipts & 2.3 & 1.2 & 1.0 & 1.1 & 1.1 & 1.1 & 1.2 & 1.2 & 1.3 & 1.3 \\
\hline Payments & 6.0 & 3.1 & 3.0 & 3.2 & 4.4 & 4.7 & 5.5 & 6.0 & 6.8 & 7.3 \\
\hline Current transfer balance & 6.0 & 4.1 & 3.4 & 2.9 & 3.2 & 3.5 & 3.6 & 4.2 & 4.9 & 4.8 \\
\hline Capital and financial account balance & 17.8 & -2.9 & 1.5 & 6.7 & 6.0 & 10.8 & 12.5 & 13.2 & 9.3 & 10.9 \\
\hline Capital account balance & 0.6 & 0.6 & 0.2 & 0.6 & 0.6 & 0.6 & 0.6 & 0.6 & 0.6 & 0.6 \\
\hline Foreign direct investment balance & 9.3 & 3.6 & 2.7 & 3.7 & 2.9 & 3.2 & 3.5 & 3.8 & 4.2 & 4.6 \\
\hline Portfolio investment balance & -0.9 & 0.5 & 0.7 & 2.0 & 4.8 & 1.8 & 2.7 & 2.6 & -1.0 & -1.0 \\
\hline Other investment balance & 8.7 & -7.6 & -2.1 & 0.4 & -2.3 & 5.3 & 5.8 & 6.2 & 5.5 & 7.7 \\
\hline General government & 0.2 & -0.5 & -0.1 & -0.3 & -1.2 & 0.0 & 0.0 & -0.2 & -1.5 & 0.0 \\
\hline Domestic banks & 3.0 & -5.5 & 0.6 & 0.0 & 0.1 & 1.2 & 1.3 & 1.5 & 1.6 & 1.8 \\
\hline Other private sector & 5.5 & -1.6 & -2.7 & 0.8 & -1.1 & 4.1 & 4.5 & 4.9 & 5.4 & 5.9 \\
\hline Errors and omissions & -1.7 & -1.0 & -0.8 & 0.0 & 0.0 & 0.0 & 0.0 & 0.0 & 0.0 & 0.0 \\
\hline Prospective financing & $\ldots$ & 2.1 & 3.7 & 3.2 & 2.8 & $\ldots$ & $\ldots$ & $\ldots$ & $\ldots$ & $\ldots$ \\
\hline European Commission & $\ldots$ & 1.5 & 2.2 & 1.4 & 1.4 & $\ldots$ & $\ldots$ & $\ldots$ & $\ldots$ & $\ldots$ \\
\hline World Bank & $\ldots$ & 0.3 & 0.0 & 0.7 & 0.3 & $\ldots$ & $\ldots$ & $\ldots$ & $\ldots$ & $\ldots$ \\
\hline EIB/EBRD/IFC & $\ldots$ & 0.3 & 1.5 & 1.2 & 1.2 & $\ldots$ & $\ldots$ & $\ldots$ & $\ldots$ & $\ldots$ \\
\hline Overall balance & 0.0 & -6.7 & -0.9 & 3.5 & 2.9 & 4.7 & 5.2 & 5.1 & 0.4 & 1.2 \\
\hline Financing & 0.0 & 6.7 & 0.9 & -3.5 & -2.9 & -4.7 & -5.2 & -5.1 & -0.4 & -1.2 \\
\hline Gross international reserves (increase: -) & 0.0 & -1.1 & -3.4 & -4.4 & -3.8 & -3.2 & -0.7 & -0.4 & 1.0 & -1.2 \\
\hline Use of Fund credit, net & 0.0 & 6.8 & 4.3 & 0.9 & 0.9 & -1.5 & -4.6 & -4.6 & -1.4 & 0.0 \\
\hline Purchases 1/ & 0.0 & 6.8 & 4.3 & 0.9 & 0.9 & 0.0 & 0.0 & 0.0 & 0.0 & 0.0 \\
\hline Repurchases & 0.0 & 0.0 & 0.0 & 0.0 & 0.0 & -1.5 & -4.6 & -4.6 & -1.4 & 0.0 \\
\hline Other liabilities, net & 0.0 & 1.0 & 0.0 & 0.0 & 0.0 & 0.0 & 0.0 & 0.0 & 0.0 & 0.0 \\
\hline Memorandum items: & \multicolumn{10}{|c|}{ (In percent of GDP) } \\
\hline Current account balance & -11.6 & -4.2 & -4.3 & -5.0 & -4.5 & -4.6 & -4.7 & -4.7 & -4.7 & -4.7 \\
\hline Foreign direct investment balance & 6.7 & 3.0 & 2.2 & 2.9 & 2.2 & 2.2 & 2.2 & 2.2 & 2.2 & 2.2 \\
\hline Merchandise trade balance & -13.7 & -5.8 & -4.9 & -5.1 & -4.0 & -4.1 & -3.8 & -3.9 & -3.9 & -3.7 \\
\hline Exports & 24.1 & 24.7 & 30.6 & 32.3 & 33.3 & 33.4 & 33.3 & 33.0 & 32.8 & 32.5 \\
\hline Imports & 37.8 & 30.6 & 35.4 & 37.4 & 37.2 & 37.4 & 37.1 & 36.9 & 36.7 & 36.3 \\
\hline Gross external financing requirement & 33.1 & 29.7 & 26.1 & 26.9 & 27.1 & 28.3 & 29.8 & 28.1 & 25.0 & 23.9 \\
\hline \multicolumn{11}{|c|}{ (Annual percentage change) } \\
\hline Terms of trade (merchandise) & 3.1 & 0.2 & 2.5 & -0.7 & -3.0 & -0.3 & -0.7 & -1.1 & -0.2 & -0.2 \\
\hline Export volume & 8.3 & -5.3 & 13.1 & 7.2 & 16.0 & 7.2 & 8.1 & 8.3 & 8.2 & 8.2 \\
\hline Import volume & 7.9 & -20.9 & 11.6 & 6.7 & 11.1 & 6.6 & 7.5 & 8.5 & 8.0 & 8.0 \\
\hline Export prices & 18.7 & 3.3 & 6.0 & 2.8 & 0.6 & 1.6 & 1.2 & 0.5 & 1.0 & 1.0 \\
\hline Import prices & 15.4 & 3.7 & 3.2 & 3.6 & 3.6 & 1.9 & 1.9 & 1.6 & 1.2 & 1.2 \\
\hline \multicolumn{11}{|c|}{ (In billions of euros) } \\
\hline Gross international reserves 2/ & 28.3 & 30.9 & 36.0 & 40.4 & 39.8 & 43.0 & 43.6 & 44.1 & 43.1 & 44.3 \\
\hline GDP & 139.7 & 117.6 & 122.1 & 127.2 & 131.0 & 142.5 & 156.3 & 172.2 & 189.7 & 208.9 \\
\hline
\end{tabular}

Sources: Romanian authorities; and Fund staff estimates and projections.

$1 /$ Includes IMF disbursement to the Treasury of $€ 0.9$ billion in 2009 and $€ 1.2$ billion in 2010.

2/ Operational defition. Reflects the allocation of SDR 908.8 million that was made avaialable in two tranches in August and

September 2009. 
Table 6. Romania: Gross Financing Requirements, 2010-12

(In billions of euros, unless otherwise indicated)

\begin{tabular}{|c|c|c|c|c|c|c|c|c|}
\hline & 2010 & & & 2011 & & & 2012 & Total \\
\hline & Year & Q1 & Q2 & Q3 & Q4 & Year & Year & $2011-12$ \\
\hline & Act & Act & Proj & Proj & Proj & Proj. & Proj. & Proj. \\
\hline I. Total financing requirements & 37.8 & 9.1 & 9.0 & 8.1 & 10.8 & 37.0 & 41.3 & 78.2 \\
\hline I.A. Current account deficit & 5.2 & 0.7 & 1.6 & 1.6 & 2.0 & 5.9 & 6.6 & 12.4 \\
\hline I.B. Short-term debt & 20.8 & 5.9 & 4.9 & 4.9 & 5.5 & 21.3 & 25.0 & 46.3 \\
\hline Public sector & 4.5 & 1.9 & 1.1 & 0.9 & 0.6 & 4.5 & 5.8 & 10.3 \\
\hline Banks & 11.2 & 2.9 & 3.0 & 2.6 & 3.6 & 12.2 & 12.5 & 24.7 \\
\hline Corporates & 5.1 & 1.1 & 0.9 & 1.4 & 1.3 & 4.6 & 6.7 & 11.3 \\
\hline I.C. Maturing medium- and long-term debt & 11.3 & 1.7 & 1.8 & 1.8 & 3.5 & 8.8 & 9.7 & 18.5 \\
\hline Public sector & 1.7 & 0.2 & 0.2 & 0.2 & 0.2 & 0.9 & 1.0 & 2.0 \\
\hline Banks & 3.1 & 0.2 & 0.5 & 0.6 & 0.7 & 2.0 & 2.2 & 4.3 \\
\hline Corporates & 6.5 & 1.3 & 1.0 & 1.0 & 2.6 & 5.9 & 6.4 & 12.3 \\
\hline I.D. Other net capital outflows $1 /$ & 0.5 & 0.8 & 0.6 & -0.2 & -0.2 & 1.0 & 0.0 & 1.0 \\
\hline II. Total financing sources & 34.2 & 8.7 & 9.6 & 8.0 & 10.7 & 37.1 & 46.0 & 83.0 \\
\hline II.A. Foreign direct investment, net & 2.6 & 0.4 & 0.7 & 1.3 & 0.5 & 2.9 & 3.2 & 6.1 \\
\hline II.B. Capital account inflows & 0.2 & 0.1 & 0.1 & 0.2 & 0.2 & 0.6 & 0.5 & 1.1 \\
\hline II.C. Short-term debt & 23.3 & 6.7 & 6.8 & 5.4 & 6.1 & 25.0 & 28.6 & 53.6 \\
\hline Public sector & 5.5 & 2.5 & 1.8 & 0.8 & 0.6 & 5.8 & 5.8 & 11.6 \\
\hline Banks & 12.5 & 2.6 & 3.6 & 2.6 & 3.6 & 12.5 & 13.8 & 26.3 \\
\hline Corporates & 5.3 & 1.5 & 1.3 & 1.9 & 1.9 & 6.7 & 9.0 & 15.7 \\
\hline II.D. Medium- and long-term debt & 8.1 & 1.5 & 2.0 & 1.2 & 3.8 & 8.5 & 13.7 & 22.3 \\
\hline Public sector & 1.9 & 0.3 & 1.5 & 0.2 & 1.4 & 3.3 & 2.8 & 6.1 \\
\hline Banks & 2.3 & 0.7 & 0.2 & 0.6 & 0.7 & 2.2 & 2.2 & 4.5 \\
\hline Corporates & 3.9 & 0.5 & 0.4 & 0.4 & 1.8 & 3.0 & 8.7 & 11.7 \\
\hline Errors and Omissions & -0.8 & -0.9 & 0.4 & 0.0 & 0.5 & 0.0 & 0.0 & -0.8 \\
\hline III. Increase in gross reserves & 3.3 & 1.2 & 1.8 & 0.2 & 0.7 & 3.8 & 3.2 & 7.1 \\
\hline IV. Financing Gap & 8.0 & 2.4 & 0.7 & 0.3 & 0.3 & 3.7 & -1.5 & 2.7 \\
\hline V. Program financing & 8.0 & 2.4 & 0.7 & 0.3 & 0.3 & 3.7 & -1.5 & 2.7 \\
\hline IMF 2/ & 4.3 & 0.9 & 0.0 & 0.0 & 0.0 & 0.9 & -1.5 & -0.6 \\
\hline Purchases & 4.3 & 0.9 & 0.0 & 0.0 & 0.0 & 0.9 & 0.0 & 0.9 \\
\hline Repurchases & & & & & & & -1.5 & -1.5 \\
\hline Others & 3.7 & 1.5 & 0.7 & 0.3 & 0.3 & 2.8 & 0.0 & 3.2 \\
\hline European Commission & 2.2 & 1.2 & 0.2 & 0.0 & 0.0 & 1.4 & 0.0 & 1.4 \\
\hline World Bank & 0.0 & 0.0 & 0.3 & 0.0 & 0.0 & 0.3 & 0.4 & 0.7 \\
\hline $\mathrm{EIB/EBRD/IFC}$ & 1.5 & 0.3 & 0.3 & 0.3 & 0.3 & 1.2 & 0.0 & 1.2 \\
\hline \multicolumn{9}{|l|}{ Memorandum items: } \\
\hline \multicolumn{9}{|l|}{ Rollover rates for amortizing debt ST (in percent) } \\
\hline Public sector & 122 & 133 & 172 & 93 & 93 & 129 & 100 & 113 \\
\hline Banks & 112 & 91 & 121 & 100 & 100 & 103 & 110 & 107 \\
\hline Corporates & 104 & 140 & 158 & 137 & 147 & 144 & 135 & 139 \\
\hline \multicolumn{9}{|c|}{ Rollover rates for amortizing debt MLT (in percent) } \\
\hline Public sector & 112 & 133 & 618 & 75 & 573 & 354 & 271 & 311 \\
\hline Banks & 74 & 349 & 41 & 100 & 100 & 109 & 100 & 104 \\
\hline Corporates & 60 & 38 & 34 & 40 & 70 & 52 & 135 & 95 \\
\hline Gross international reserves 3 / & 36.0 & $\ldots$ & $\ldots$ & $\ldots$ & $\ldots$ & 39.8 & 43.0 & $\ldots$ \\
\hline \multicolumn{9}{|l|}{ Coverage of gross international reserves } \\
\hline - Months of imports of GFNS (next year) & 6.0 & $\ldots$ & $\ldots$ & $\ldots$ & $\ldots$ & 5.8 & 5.8 & $\ldots$ \\
\hline - Short-term external debt (in percent) & 121.2 & & $\ldots$ & $\ldots$ & $\ldots$ & 117.7 & 109.4 & \\
\hline
\end{tabular}

Source: IMF staff estimates.

$1 /$ Includes includes portfolio equity, financial derivatives and other investments, assets position.

2/ Last disbursement of the current program is treated as precautionary

3/ Operation Definition 
Table 7. Romania: General Government Operations, 2007-12

(In percent of GDP)

\begin{tabular}{|c|c|c|c|c|c|c|c|}
\hline & 2007 & 2008 & 2009 & 2010 & $\begin{array}{r}2011 \\
\text { 1st Rev. }\end{array}$ & $\begin{array}{r}2011 \\
\text { Proj } 7 /\end{array}$ & $\begin{array}{l}2012 \\
\text { Proj. }\end{array}$ \\
\hline Revenue & 32.3 & 32.2 & 31.4 & 32.8 & 33.1 & 33.5 & 33.9 \\
\hline Taxes & 27.9 & 27.9 & 27.4 & 27.0 & 27.9 & 28.2 & 28.1 \\
\hline Corporate income tax & 2.9 & 2.8 & 2.7 & 2.1 & 1.9 & 2.0 & 2.0 \\
\hline Personal income tax & 3.5 & 3.6 & 3.7 & 3.5 & 3.5 & 3.5 & 3.5 \\
\hline VAT & 7.5 & 7.9 & 6.9 & 7.6 & 8.5 & 8.6 & 8.5 \\
\hline Excises & 3.0 & 2.7 & 3.1 & 3.4 & 3.4 & 3.7 & 3.7 \\
\hline Customs duties & 0.2 & 0.2 & 0.1 & 0.1 & 0.1 & 0.1 & 0.1 \\
\hline Social security contributions & 9.5 & 9.5 & 9.6 & 8.9 & 9.1 & 9.0 & 9.0 \\
\hline Other taxes & 1.4 & 1.2 & 1.2 & 1.3 & 1.3 & 1.3 & 1.3 \\
\hline Nontax revenue & 3.4 & 3.1 & 2.9 & 3.9 & 3.5 & 3.6 & 3.3 \\
\hline Capital revenue & 0.2 & 0.2 & 0.1 & 0.1 & 0.1 & 0.1 & 0.1 \\
\hline Grants, including EU disbursements & 0.8 & 0.9 & 1.0 & 1.8 & 1.6 & 1.6 & 2.4 \\
\hline Expenditure & 35.4 & 37.0 & 38.7 & 39.4 & 37.5 & 37.9 & 36.7 \\
\hline Current expenditure & 30.7 & 32.5 & 34.8 & 35.7 & 33.7 & 34.2 & 32.8 \\
\hline Compensation of employees & 8.1 & 8.9 & 9.4 & 8.3 & 7.5 & 7.5 & 7.2 \\
\hline Goods and services & 6.1 & 6.2 & 5.6 & 5.8 & 5.5 & 5.4 & 5.3 \\
\hline Interest & 0.7 & 0.7 & 1.2 & 1.4 & 1.7 & 1.8 & 1.7 \\
\hline Subsidies & 1.7 & 1.5 & 1.4 & 1.3 & 1.1 & 1.2 & 0.9 \\
\hline Transfers & 14.1 & 15.1 & 16.7 & 18.5 & 17.6 & 17.9 & 17.4 \\
\hline Pensions 1/ & 5.4 & 6.4 & 8.0 & 8.2 & 8.6 & 8.8 & 8.7 \\
\hline Other social transfers & 3.9 & 4.1 & 4.8 & 5.2 & 3.9 & 3.8 & 3.5 \\
\hline Other transfers 2/ & 4.0 & 3.4 & 3.4 & 4.6 & 4.6 & 4.9 & 4.8 \\
\hline Other spending & 0.7 & 1.2 & 0.5 & 0.6 & 0.4 & 0.5 & 0.5 \\
\hline Proj. with ext. credits & 0.0 & 0.0 & 0.4 & 0.3 & 0.4 & 0.4 & 0.2 \\
\hline Capital expenditure 3/ & 4.7 & 4.6 & 4.4 & 3.8 & 3.7 & 3.7 & 3.8 \\
\hline Reserve fund & 0.0 & 0.0 & 0.0 & 0.0 & 0.0 & 0.0 & 0.0 \\
\hline Net lending and expense refunds & 0.0 & -0.1 & -0.5 & -0.1 & 0.0 & 0.0 & 0.0 \\
\hline Fiscal balance & -3.1 & -4.8 & -7.3 & -6.5 & -4.4 & -4.4 & -2.8 \\
\hline Primary balance & -2.4 & -4.1 & -6.1 & -5.1 & -2.7 & -2.6 & -1.1 \\
\hline Financing & 3.1 & 4.8 & 7.3 & 6.5 & 4.4 & 4.4 & 2.8 \\
\hline Privatization proceeds & 0.1 & 0.1 & 0.0 & 0.1 & 0.1 & 0.1 & 0.1 \\
\hline External & 0.1 & 0.4 & 2.9 & 2.9 & 2.4 & 2.2 & 1.4 \\
\hline Domestic & 2.9 & 4.3 & 4.4 & 3.6 & 1.9 & 2.2 & 1.3 \\
\hline \multicolumn{8}{|l|}{ Financial liabilities } \\
\hline Gross public debt $4 /$ & 12.7 & 13.6 & 23.9 & 31.7 & 34.3 & 34.4 & 34.4 \\
\hline Gross public debt excl. guarantees & 10.4 & 11.8 & 21.8 & 28.7 & 31.4 & 31.5 & 31.8 \\
\hline External & 7.0 & 7.0 & 10.0 & 13.2 & 14.8 & 14.6 & 14.9 \\
\hline Domestic & 3.4 & 4.9 & 11.8 & 15.5 & 16.6 & 16.8 & 16.8 \\
\hline \multicolumn{8}{|l|}{ Memorandum items: } \\
\hline Total capital spending & $\ldots$ & 6.3 & 5.3 & 7.4 & 7.1 & 7.2 & 7.3 \\
\hline Fiscal balance (ESA95 basis) & -2.5 & -5.4 & -8.3 & $\ldots$ & $\ldots$ & $\ldots$ & $\ldots$ \\
\hline Output gap $5 /$ & 7.6 & 10.0 & -0.8 & -3.7 & -4.6 & -4.7 & -3.8 \\
\hline Conventional structural fiscal balance & -5.8 & -8.5 & -7.0 & -5.1 & -2.7 & -2.6 & -1.4 \\
\hline Gross public debt (authorities definition) 6/ & 19.8 & 21.3 & 29.6 & 37.9 & & & \\
\hline Nominal GDP (in billions of RON) & 416.0 & 514.7 & 498.0 & 513.6 & 542.9 & 543.0 & 588.9 \\
\hline
\end{tabular}

Sources: Ministry of Finance; Eurostat; and Fund staff projections.

$1 / 2011$ pension increase partly due to a reclassification of pensions from state budget to the pension fund.

2/ Includes EU-financed capital projects.

3/ Does not include all capital spending.

4/ Total consolidated public debt, including government debt, local government debt, and guarantees .

5/ Percentage deviation of actual from potential GDP.

$6 /$ Includes guarantees and intra-governmental debt.

$7 /$ Includes arrears reduction plans in VAT ( $551 \mathrm{~m})$, nontax revenues $(876 \mathrm{~m})$, subsidies $(736 \mathrm{~m})$, other transfers $(454 \mathrm{~m}$ ) and other social transfers $(237 \mathrm{~m})$. 
Table 7. Romania: General Government Operations, 2007-12 (concluded) (In millions of RON)

\begin{tabular}{|c|c|c|c|c|c|c|}
\hline & 2008 & 2009 & 2010 & $\begin{array}{c}2011 \\
\text { 1st Rev. }\end{array}$ & $\begin{array}{c}2011 \\
\text { Proj 5/ }\end{array}$ & $\begin{array}{c}2012 \\
\text { Proj }\end{array}$ \\
\hline Revenue & 165,549 & 156,373 & 168,635 & 179,725 & 182,126 & 199,450 \\
\hline Taxes & 143,855 & 136,350 & 138,667 & 151,520 & 153,232 & 165,428 \\
\hline Corporate income tax & 14,426 & 13,466 & 10,969 & 10,430 & 10,686 & 11,876 \\
\hline Personal income tax & 18,523 & 18,551 & 17,957 & 18,828 & 18,827 & 20,418 \\
\hline VAT & 40,874 & 34,322 & 39,246 & 46,232 & 46,882 & 50,247 \\
\hline Excises & 13,646 & 15,646 & 17,312 & 18,652 & 20,056 & 21,751 \\
\hline Customs duties & 962 & 656 & 574 & 614 & 657 & 716 \\
\hline Social security contributions & 49,008 & 47,829 & 45,704 & 49,500 & 49,143 & 52,847 \\
\hline Other taxes & 6,416 & 5,879 & 6,905 & 7,264 & 6,982 & 7,572 \\
\hline Nontax revenue & 15,892 & 14,487 & 19,796 & 18,971 & 19,427 & 19,221 \\
\hline Capital revenue & 1,076 & 546 & 685 & 477 & 701 & 760 \\
\hline Grants & 4,702 & 5,057 & 9,494 & 8,757 & 8,766 & 14,041 \\
\hline o/w EU pre-accession funds & $\ldots$ & 2,959 & 4,054 & 951 & 960 & 446 \\
\hline Financial operations and other & 25 & -67 & -6 & 0 & 0 & 0 \\
\hline Expenditure & 190,407 & 192,782 & 202,256 & 203,680 & 206,080 & 215,979 \\
\hline Current expenditure & 167,095 & 173,445 & 183,243 & 183,161 & 185,526 & 193,211 \\
\hline Compensation of employees & 45,608 & 46,676 & 42,839 & 40,570 & 40,570 & 42,500 \\
\hline Goods and services & 32,012 & 28,028 & 29,541 & 29,643 & 29,217 & 31,356 \\
\hline Interest & 3,776 & 6,063 & 7,275 & 9,500 & 9,597 & 10,129 \\
\hline Subsidies & 7,899 & 7,215 & 6,735 & 5,780 & 6,753 & 5,367 \\
\hline Transfers & 77,800 & 83,407 & 95,060 & 95,525 & 97,281 & 102,550 \\
\hline Pensions & 33,187 & 39,851 & 42,107 & 46,958 & 47,769 & 51,014 \\
\hline Other social transfers & 20,973 & 24,101 & 26,505 & 21,150 & 20,691 & 20,676 \\
\hline Other transfers $1 /$ & 17,646 & 16,931 & 23,514 & 24,984 & 26,344 & 28,029 \\
\hline Other spending & 5,993 & 2,523 & 2,933 & 2,433 & 2,477 & 2,831 \\
\hline Proj. with ext. credits & 0 & 2,056 & 1,794 & 2,142 & 2,106 & 1,310 \\
\hline Capital expenditure 2/ & 23,779 & 21,828 & 19,441 & 20,313 & 20,304 & 22,596 \\
\hline Reserve fund & 0 & 0 & 0 & 207 & 243 & 172 \\
\hline Net lending and expense refunds & -467 & $-2,490$ & -428 & 0 & 7 & 0 \\
\hline Fiscal balance & $-24,858$ & $-36,409$ & $-33,621$ & $-23,955$ & $-23,953$ & $-16,529$ \\
\hline Primary balance & $-21,082$ & $-30,346$ & $-26,346$ & $-14,455$ & $-14,356$ & $-6,401$ \\
\hline Financing & 24,858 & 36,409 & 33,621 & 23,955 & 23,953 & 16,529 \\
\hline Privatization proceeds & 371 & 0 & 289 & 400 & 400 & 400 \\
\hline External & 2,284 & 14,343 & 15,001 & 13,020 & 11,786 & 8,341 \\
\hline Domestic & 22,000 & 22,067 & 18,331 & 10,535 & 11,767 & 7,788 \\
\hline \multicolumn{7}{|l|}{ Financial liabilities } \\
\hline Gross public debt $3 /$ & 70,200 & 119,195 & 163,023 & 186,413 & 186,576 & 202,705 \\
\hline Gross public debt excl. guarantees & 60,883 & 108,527 & 147,347 & 170,738 & 170,900 & 187,030 \\
\hline External & 35,775 & 49,993 & 67,685 & 80,553 & 79,471 & 87,812 \\
\hline Domestic & 25,108 & 58,535 & 79,663 & 90,185 & 91,430 & 99,218 \\
\hline \multicolumn{7}{|l|}{ Other liabilities } \\
\hline \multicolumn{7}{|l|}{ Memorandum item: } \\
\hline Gross public debt (authorities definition) 4/ & 109,795 & 147,329 & 194,459 & & & \\
\hline
\end{tabular}

Sources: Ministry of Finance; Eurostat; and Fund staff projections.

$1 /$ Includes EU-financed capital projects.

2/ Does not include all capital spending.

3/ Total consolidated public debt, including government debt, local government debt, and guarantees.

$4 /$ Includes guarantees and intra-governmental debt.

$5 /$ Includes arrears reduction plans in VAT $(551 \mathrm{~m})$, nontax revenues $(876 \mathrm{~m})$, subsidies $(736 \mathrm{~m})$, other transfers $(45$ and other social transfers $(237 \mathrm{~m})$. 
Table 8. Romania: Monetary Survey, 2009-12

(In millions of lei (RON), unless otherwise indicated; end of period)

\begin{tabular}{|c|c|c|c|c|c|c|c|}
\hline & \multirow[t]{2}{*}{ Dec-09 } & \multirow[t]{2}{*}{ Dec-10 } & \multicolumn{4}{|c|}{2011} & \multirow{2}{*}{$\begin{array}{r}\text { Dec-12 } \\
\text { Proj } \\
\end{array}$} \\
\hline & & & Q1 & Q2 & Q3 Proj. & Q4 Proj. & \\
\hline & \multicolumn{7}{|c|}{ I. Banking System } \\
\hline Net foreign assets & 17,684 & 18,776 & 12,348 & 23,789 & 24,336 & 33,317 & 36,299 \\
\hline In million euros & 4,182 & 4,382 & 3,001 & 5,619 & 5,902 & 8,061 & 8,778 \\
\hline o/w commercial banks & $-19,708$ & $-21,158$ & $-21,375$ & $-21,961$ & $-21,961$ & $-20,523$ & $-20,500$ \\
\hline Net domestic assets & 171,946 & 183,987 & 183,982 & 176,123 & 182,114 & 186,203 & 207,509 \\
\hline Public sector credit & 26,748 & 43,393 & 39,813 & 34,083 & 43,583 & 53,324 & 69,129 \\
\hline Private sector credit & 199,887 & 209,298 & 203,956 & 213,651 & 216,142 & 217,959 & 234,010 \\
\hline Other & $-54,688$ & $-68,704$ & $-59,787$ & $-71,611$ & $-77,611$ & $-85,080$ & $-95,630$ \\
\hline Broad Money (M3) & 189,630 & 202,763 & 196,331 & 199,912 & 206,450 & 219,520 & 243,808 \\
\hline Money market instruments & 1,617 & 3,177 & 3,430 & 3,822 & 4,230 & 4,765 & 7,148 \\
\hline Intermediate money (M2) & 188,013 & 199,586 & 192,901 & 196,090 & 202,220 & 214,755 & 236,660 \\
\hline Narrow money (M1) & 79,361 & 81,605 & 77,759 & 80,045 & 80,994 & 90,517 & 97,862 \\
\hline Currency in circulation & 23,968 & 26,793 & 26,238 & 26,953 & 26,289 & 32,122 & 34,729 \\
\hline \multirow[t]{2}{*}{ Overnight deposits } & 55,394 & 54,812 & 51,521 & 53,092 & 54,705 & 58,395 & 63,134 \\
\hline & \multicolumn{7}{|c|}{ II. National Bank of Romania } \\
\hline Net foreign assets & 101,015 & 109,433 & 100,288 & 116,774 & 114,892 & 118,137 & 121,065 \\
\hline In million euros & 23,891 & 25,540 & 24,377 & 27,580 & 27,863 & 28,585 & 29,278 \\
\hline Net domestic assets & $-49,354$ & $-54,330$ & $-50,408$ & $-64,476$ & $-61,955$ & $-58,976$ & $-57,103$ \\
\hline Public sector credit, net & $-13,626$ & $-12,795$ & $-16,386$ & $-27,757$ & $-21,274$ & $-16,795$ & $-16,795$ \\
\hline Credit to banks, net & $-23,848$ & $-26,148$ & $-27,330$ & $-22,610$ & $-19,610$ & $-20,610$ & $-28,610$ \\
\hline \multirow{3}{*}{$\begin{array}{l}\text { Other } \\
\text { Reserve money }\end{array}$} & $-11,880$ & $-15,387$ & $-6,692$ & $-14,109$ & $-21,071$ & $-21,571$ & $-11,698$ \\
\hline & 51,662 & 55,103 & 49,881 & 52,298 & 52,937 & 59,161 & 63,962 \\
\hline & \multicolumn{7}{|c|}{ (Annual percentage change) } \\
\hline Broad money (M3) & 9.0 & 6.9 & 3.3 & 2.5 & 5.5 & 8.3 & 11.1 \\
\hline NFA contribution & 2.6 & 0.6 & -7.2 & -1.6 & 0.0 & 7.2 & 1.4 \\
\hline NDA contribution & 6.4 & 6.3 & 10.6 & 4.1 & 5.4 & 1.1 & 9.7 \\
\hline Reserve money & 2.4 & 6.7 & 9.0 & 6.5 & 7.0 & 7.4 & 8.1 \\
\hline NFA contribution & -18.4 & 16.3 & -17.1 & -2.4 & 8.4 & 15.8 & 4.9 \\
\hline NDA contribution & 20.8 & -9.6 & 26.1 & 8.8 & -1.3 & -8.4 & 3.2 \\
\hline Domestic credit, real & 5.5 & 3.2 & 2.2 & -5.5 & 3.3 & 1.5 & 8.5 \\
\hline Private sector, real & -3.7 & -3.0 & -5.2 & -6.3 & -1.1 & -1.6 & 4.2 \\
\hline Public sector, real & 159.7 & 21.9 & 12.3 & 18.0 & 22.7 & 9.7 & 18.5 \\
\hline Broad money (M3), in real terms & 4.0 & -1.0 & -4.2 & -5.3 & 0.3 & 2.3 & 7.8 \\
\hline Private deposits, at constant $\mathrm{e} / \mathrm{r}$ & 8.1 & 5.0 & 1.8 & 3.2 & 6.4 & 8.3 & 9.6 \\
\hline Private credit, nominal & 0.9 & 4.7 & 2.3 & 1.3 & 3.9 & 4.1 & 7.4 \\
\hline \multicolumn{8}{|l|}{ Memorandum items } \\
\hline CPI inflation, eop & 4.7 & 8.0 & 7.6 & 8.0 & 4.8 & 5.0 & 3.8 \\
\hline Inflation target & $2.5-4.5$ & $2.5-4.5$ & $2.0-4.0$ & $2.0-4.0$ & $2.0-4.0$ & $2.0-4.0$ & $2.0-4.0$ \\
\hline \multicolumn{8}{|l|}{ Interest rates (percent): } \\
\hline Policy interest rate & 8.00 & 6.25 & 6.25 & 6.25 & $\ldots$ & $\ldots$ & $\ldots$ \\
\hline Interbank offer rate, 1 week & 10.7 & 3.6 & 5.1 & 4.3 & $\ldots$ & $\ldots$ & $\cdots$ \\
\hline Corporate loans $1 /$ & 15.4 & 9.4 & 9.8 & 9.3 & $\begin{array}{l}\cdots \\
\cdots\end{array}$ & $\cdots$ & $\begin{array}{l}\cdots \\
\cdots\end{array}$ \\
\hline Household time deposits $1 /$ & 9.9 & 7.6 & 7.1 & 6.7 & $\begin{array}{l}\cdots \\
\cdots\end{array}$ & $\begin{array}{l}\cdots \\
\ldots\end{array}$ & $\begin{array}{l}\cdots \\
\cdots\end{array}$ \\
\hline Share of foreign currency private deposits & 38.8 & 36.1 & 35.8 & 34.7 & $\ldots$ & $\ldots$ & $\ldots$ \\
\hline Share of foreign currency private loans & 60.1 & 63.0 & 62.2 & 62.9 & $\ldots$ & $\ldots$ & $\ldots$ \\
\hline M2 velocity & 2.65 & 2.57 & 2.56 & 2.55 & 2.55 & 2.59 & 2.67 \\
\hline Money multiplier (M3/reserve money) & 3.67 & 3.68 & 3.94 & 3.82 & 3.90 & 3.71 & 3.81 \\
\hline
\end{tabular}

Sources: National Bank of Romania; and Fund staff estimates.

1/ Rates for new local currency denominated transactions. 
Table 9. Romania: Financial Soundness Indicators, 2008-11 (In percent)

\begin{tabular}{|c|c|c|c|c|c|c|c|c|c|c|c|}
\hline & $\begin{array}{l}2008 \\
\text { Dec. }\end{array}$ & $\begin{array}{l}2009 \\
\text { Mar. }\end{array}$ & $\begin{array}{c}2009 \\
\text { Jun. }\end{array}$ & $\begin{array}{l}2009 \\
\text { Sep. }\end{array}$ & $\begin{array}{l}2009 \\
\text { Dec. }\end{array}$ & $\begin{array}{l}2010 \\
\text { Mar. }\end{array}$ & $\begin{array}{c}2010 \\
\text { Jun. }\end{array}$ & $\begin{array}{l}2010 \\
\text { Sep. }\end{array}$ & $\begin{array}{l}2010 \\
\text { Dec. }\end{array}$ & $\begin{array}{l}2011 \\
\text { Mar. }\end{array}$ & $\begin{array}{l}2011 \\
\text { June }\end{array}$ \\
\hline \multicolumn{12}{|l|}{ Core indicators } \\
\hline \multicolumn{12}{|l|}{ Capital adequacy } \\
\hline Capital to risk-weighted assets & 13.8 & 13.2 & 13.5 & 13.7 & 14.7 & 15.0 & 14.3 & 14.6 & 15.02 & 14.88 & 14.19 \\
\hline Tier 1 capital to risk-weighted assets & 11.8 & 11.4 & 11.9 & 12.0 & 13.4 & 14.2 & 13.4 & 13.8 & 14.22 & 14.49 & 13.61 \\
\hline \multicolumn{12}{|l|}{ Asset quality } \\
\hline Nonperforming loans $(1 /)$ to total gross loans & 2.8 & 4.0 & 4.7 & 6.5 & 7.9 & 9.1 & 10.2 & 11.7 & 11.85 & 12.71 & 13.35 \\
\hline Nonperforming loans (1/) net of provisions to capital & 10.7 & 15.9 & 24.3 & 8.8 & 11.3 & 12.6 & 14.5 & 16.3 & 15.70 & 15.70 & 16.49 \\
\hline \multicolumn{12}{|l|}{ Earnings and profitability } \\
\hline Return on assets & 1.6 & -0.3 & 0.1 & 0.3 & 0.2 & 0.5 & -0.1 & -0.2 & -0.16 & 0.46 & 0.06 \\
\hline Return on equity ( $2 /)$ & 17.0 & -2.9 & 0.6 & 3.2 & 2.9 & 6.0 & -1.6 & -2.1 & -1.73 & 5.00 & 0.62 \\
\hline Net interest income to operating income & 44.8 & 38.9 & 38.4 & 41.8 & 44.1 & 55.7 & 58.2 & 58.7 & 60.61 & 59.78 & 63.70 \\
\hline Noninterest expense to operating income (cost to income) & 55.7 & 57.1 & 67.2 & 65.4 & 63.9 & 56.5 & 59.2 & 58.6 & 64.85 & 65.61 & 67.46 \\
\hline Personnel expense to operating income & 23.4 & 21.4 & 22.8 & 21.4 & 20.3 & 20.7 & 21.6 & 21.2 & 20.95 & 22.76 & 23.29 \\
\hline \multicolumn{12}{|l|}{ Liquidity } \\
\hline Liquid assets (3/)to total assets & 47.1 & 51.7 & 54.7 & 53.9 & 57.4 & 58.6 & 59.1 & 59.3 & 60.04 & 58.84 & 58.73 \\
\hline Liquid assets $(3 /)$ to short-term liabilities $(4 /)$ & 230.5 & 226.3 & 261.9 & 136.3 & 132.0 & 150.0 & 146.7 & 148.7 & 142.20 & 151.84 & 143.48 \\
\hline Liquid assets $(3 /)$ to total attracted and borrowed sources & 116.2 & 119.2 & 130.6 & 87.7 & 79.4 & 81.2 & 79.8 & 82.1 & 80.92 & 80.49 & 80.36 \\
\hline \multicolumn{12}{|l|}{ Foreign exchange risk } \\
\hline Net open position in foreign exchange, in percent of capital & 1.6 & -2.3 & -2.5 & 1.7 & 2.3 & 1.6 & -3.2 & 1.4 & -1.43 & -2.85 & -3.44 \\
\hline Lending in foreign exchange, in percent of non-gov. credit & 57.8 & 59 & 59.1 & 59.7 & 60.1 & 60.4 & 62.8 & 62.5 & 63.00 & 62.20 & 62.93 \\
\hline Foreign currency liabilities, in percent of total attracted and borrowed sources & 43.7 & 42.3 & 41.8 & 44.1 & 42.8 & 43.6 & 44.7 & 44.1 & 43.54 & 43.84 & 43.16 \\
\hline Deposits in foreign exchange, in percent of non-gov. dom. deposits & 34.8 & 37.1 & 35.6 & 37.8 & 38.8 & 37 & 38 & 37.4 & 36.00 & 35.60 & 34.64 \\
\hline \multicolumn{12}{|l|}{ Encouraged indicators } \\
\hline \multicolumn{12}{|l|}{ Deposit-taking institutions } \\
\hline Leverage ratio $(5 /)$ & 8.1 & 6.8 & 6.9 & 6.9 & 7.6 & 8.1 & 7.9 & 7.0 & 8.11 & 7.96 & 7.79 \\
\hline Personnel expenses to noninterest expenses & 41.9 & 37.5 & 33.9 & 32.7 & 31.8 & 36.6 & 36.4 & 36.1 & 32.30 & 34.69 & 34.53 \\
\hline Customer deposits to total (non-interbank) loans & 81.9 & 80.2 & 83.9 & 85.1 & 88.7 & 88.3 & 85.1 & 86.0 & 88.14 & 87.12 & 84.45 \\
\hline
\end{tabular}

Source: Romanian National Bank.

1/ The NPLs represent un-adjusted exposures of loans and related interests overdue for more than 90 days and/or for which legal proceedings were initiated. 2/ Return on equity is calculated as Net profit/loss to average own capital.

$3 /$ Liquid assets = balance sheet assets and off balance sheets items with residual maturity of up to 3 months.

4/ Short term liabilities =balance sheet liabilities and off balance sheet items with residual maturity of up to 3 months.

5/ Tier 1 Capital to average assets. 
Table 10. Romania: Schedule of Reviews and Purchases

\begin{tabular}{lccl}
\hline & \multicolumn{2}{c}{ Amount of Purchase } & \\
\cline { 2 - 3 } Date & Millions of SDRs & Percent of Quota & Conditions \\
\hline March 25, 2011 & 60.0 & 5.82 & Approval of arrangement \\
June 27, 2011 & 430.0 & 41.74 & First review and end-March 2011 performance criteria \\
September 28, 2011 & 430.0 & 41.74 & Second review and end-June 2011 performance criteria \\
December 15, 2011 & 430.0 & 41.74 & Third review and end-September 2011 performance criteria \\
March 15, 2012 & 430.0 & 41.74 & Fourth review and end-December 2011 performance criteria \\
June 15, 2012 & 430.0 & 41.74 & Fifth review and end-March 2012 performance criteria \\
September 15, 2012 & 430.0 & 41.74 & Sixth review and end-June 2012 performance criteria \\
December 15, 2012 & 430.0 & 41.74 & Seventh review and end-September 2012 performance criteria \\
March 15, 2013 & 20.6 & 2.00 & Eigth review and end-December 2012 performance criteria \\
& & & \\
Total & 3090.6 & 300 &
\end{tabular}

Source: IMF staff estimates. 
Table 11. Romania: Indicators of Fund Credit, 2011-16 1/ (In millions of SDR)

\begin{tabular}{|c|c|c|c|c|c|c|}
\hline & 2011 & 2012 & 2013 & 2014 & 2015 & 2016 \\
\hline \multicolumn{7}{|l|}{ Existing Fund Credit } \\
\hline Stock 2/ & 10,569 & 9,262 & 5,210 & 1,329 & 96 & 0 \\
\hline Obligations 3/ & 38 & 1,453 & 4,165 & 3,934 & 1,245 & 98 \\
\hline Repurchase & 0 & 1307 & 4052 & 3881 & 1233 & 96 \\
\hline Charges & 38 & 146 & 114 & 52 & 12 & 2 \\
\hline \multicolumn{7}{|c|}{ Prospective Fund Credit under Stand-By Arrangement } \\
\hline Disbursement & 1,350 & 1,720 & 21 & 0 & 0 & 0 \\
\hline Stock 2/ & 1,350 & 3,070 & 3,091 & 2,976 & 1,978 & 550 \\
\hline Obligations 3/ & 8 & 33 & 42 & 158 & 1,036 & 1,450 \\
\hline Repurchase & 0 & 0 & 0 & 115 & 998 & 1,428 \\
\hline Charges & 8 & 33 & 42 & 43 & 38 & 22 \\
\hline \multicolumn{7}{|l|}{ Stock of existing and prospective Fund credit } \\
\hline In millions of SDR & 11,919 & 12,332 & 8,301 & 4,304 & 2,074 & 550 \\
\hline In percent of quota & 1,157 & 1,197 & 806 & 418 & 201 & 53 \\
\hline In percent of GDP & 10.2 & 9.7 & 6.0 & 2.8 & 1.2 & 0.3 \\
\hline In percent of exports of goods and services & 26.2 & 24.9 & 15.4 & 7.4 & 3.3 & 0.8 \\
\hline In percent of gross reserves & 33.9 & 32.5 & 21.6 & 11.2 & 5.5 & 1.4 \\
\hline \multicolumn{7}{|c|}{ Obligations to the Fund from existing and prospective Fund arrangements } \\
\hline In millions of SDR & 85 & 1,693 & 4,448 & 4,201 & 2,297 & 1,548 \\
\hline In percent of quota & 8.3 & 164.3 & 431.7 & 407.8 & 223.0 & 150.3 \\
\hline In percent of GDP & 0.1 & 1.3 & 3.2 & 2.8 & 1.4 & 0.9 \\
\hline In percent of exports of goods and services & 0.2 & 3.4 & 8.2 & 7.2 & 3.6 & 2.2 \\
\hline In percent of gross reserves & 0.2 & 4.5 & 11.6 & 10.9 & 6.1 & 4.1 \\
\hline
\end{tabular}

Source: IMF staff estimates.

$1 /$ Using IMF actual disbursements, SDR interest rate as well as exchange rate of SDR/US $\$$ and US\$/€ of March 2, 2011.

2/ End of period.

3/ Repayment schedule based on repurchase obligations. 
Table 12. Romania: Public Sector Debt Sustainability Framework, 2006-16

(In percent of GDP, unless otherwise indicated)

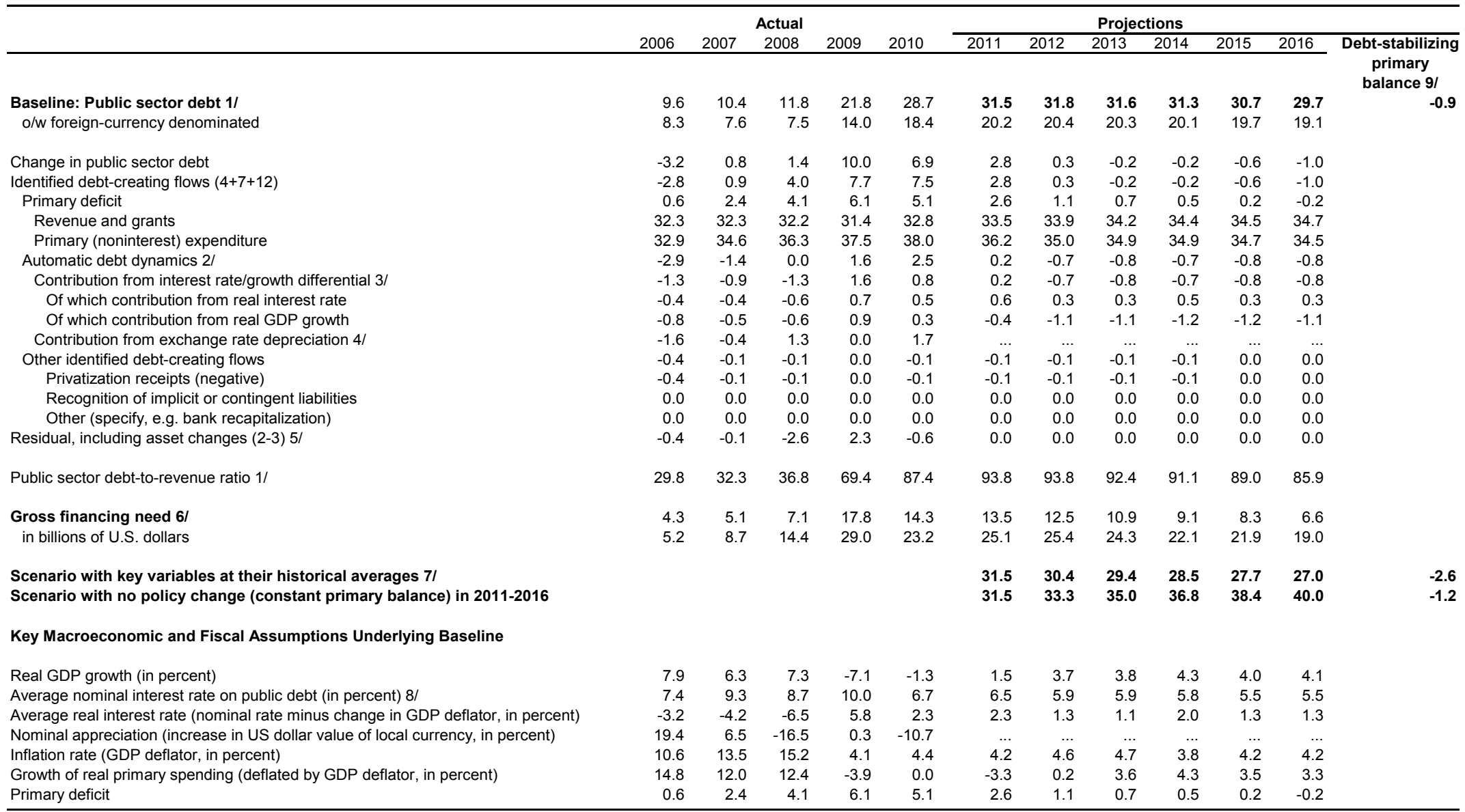

$1 /$ Coverage: General government gross debt, excluding guarantees.

2/ Derived as $[(r-\pi(1+g)-g+\alpha \varepsilon(1+r)] /(1+g+\pi+g \pi))$ times previous period debt ratio, with $r=$ interest rate; $\pi=$ growth rate of GDP deflator; $g=$ real GDP growth rate; $\alpha=$ share of foreign-currency

denominated debt; and $\varepsilon=$ nominal exchange rate depreciation (measured by increase in local currency value of U.S. dollar).

$3 /$ The real interest rate contribution is derived from the denominator in footnote $2 /$ as $r-\pi(1+g)$ and the real growth contribution as $-\mathrm{g}$.

$4 /$ The exchange rate contribution is derived from the numerator in footnote $2 /$ as $\alpha \varepsilon(1+r)$.

5/ For projections, this line includes exchange rate changes.

$6 /$ Defined as public sector defich, plus amortization of medium and long-term public sector debt, plus short-term debt at end of previous period.

7/ The key variables include real GDP growth; real interest rate; and primary balance in percent of GDP.

9/ Assumes that key variables (real GDP growth, real interest rate, and other identified debt-creating flows) remain at the level of the last projection year. 
Table 13. Romania: External Debt Sustainability Framework, 2006-16

(In percent of GDP, unless otherwise indicated)

\begin{tabular}{|c|c|c|c|c|c|c|c|c|c|c|c|c|}
\hline & \multicolumn{5}{|c|}{ Actual } & \multicolumn{7}{|c|}{ Projections } \\
\hline & 2006 & 2007 & 2008 & 2009 & 2010 & 2011 & 2012 & 2013 & 2014 & 2015 & 2016 & Debt-stabilizing \\
\hline Baseline: External debt & 42.1 & 47.1 & 51.8 & 69.0 & 74.7 & 75.4 & 73.3 & 69.4 & 65.5 & 61.1 & 58.9 & $\begin{array}{l}\text { current account } 6 / \\
-5.8\end{array}$ \\
\hline Change in external debt & 3.3 & 4.9 & 4.8 & 17.2 & 5.7 & 0.7 & -2.1 & -3.9 & -3.9 & -4.4 & -2.2 & \\
\hline Identified external debt-creating flows $(4+8+9)$ & -5.4 & -1.4 & 0.4 & 10.5 & -1.0 & -2.4 & -1.4 & -1.8 & -1.7 & 0.6 & 0.7 & \\
\hline Current account deficit, excluding interest payments & 9.2 & 12.2 & 10.1 & 2.4 & 2.7 & 2.4 & 2.7 & 2.9 & 3.1 & 3.2 & 3.4 & \\
\hline Deficit in balance of goods and services & 12.0 & 14.0 & 13.2 & 6.1 & 5.5 & 4.4 & 4.5 & 4.2 & 4.3 & 4.3 & 4.1 & \\
\hline Exports & 32.1 & 29.2 & 30.4 & 30.7 & 35.8 & 38.9 & 39.0 & 39.0 & 38.6 & 38.3 & 38.2 & \\
\hline Imports & 44.2 & 43.2 & 43.6 & 36.8 & 41.2 & 43.3 & 43.6 & 43.2 & 42.9 & 42.7 & 42.3 & \\
\hline Net non-debt creating capital inflows (negative) & -8.6 & -5.8 & -6.1 & -3.4 & -2.8 & -5.9 & -3.4 & -3.9 & -3.7 & -1.7 & -1.7 & \\
\hline Automatic debt dynamics $1 /$ & -6.0 & -7.8 & -3.6 & 11.5 & -1.0 & 1.0 & -0.6 & -0.7 & -1.1 & -1.0 & -1.0 & \\
\hline Contribution from nominal interest rate & 1.2 & 1.2 & 1.5 & 1.8 & 1.6 & 2.1 & 1.9 & 1.8 & 1.6 & 1.4 & 1.3 & \\
\hline Contribution from real GDP growth & -2.5 & -2.1 & -3.1 & 4.4 & 0.8 & -1.0 & -2.6 & -2.5 & -2.7 & -2.4 & -2.3 & \\
\hline Contribution from price and exchange rate changes $2 /$ & -4.7 & -7.0 & -2.0 & 5.4 & -3.4 & $\ldots$ & $\ldots$ & $\ldots$ & $\ldots$ & $\ldots$ & $\ldots$ & \\
\hline Residual, incl. change in gross foreign assets (2-3) $3 /$ & 8.8 & 6.4 & 4.3 & 6.7 & 6.7 & 3.1 & -0.6 & -2.2 & -2.2 & -5.0 & -2.9 & \\
\hline External debt-to-exports ratio (in percent) & 131.0 & 160.9 & 170.3 & 224.5 & 209.0 & 193.6 & 187.8 & 178.0 & 169.7 & 159.3 & 154.2 & \\
\hline Gross external financing need (in billions of Euros) 4/ & 21.7 & 35.9 & 46.2 & 34.9 & 31.9 & 35.5 & 40.4 & 46.6 & 48.3 & 47.3 & 49.9 & \\
\hline in percent of GDP & 22.2 & 28.8 & 33.1 & 29.7 & 26.1 & 27.1 & 28.3 & 29.8 & 28.1 & 25.0 & 23.9 & \\
\hline Scenario with key variables at their historical averages 5 / & & & & & & 75.4 & 73.4 & 70.5 & 67.5 & 62.1 & 58.6 & -9.6 \\
\hline \multicolumn{13}{|l|}{ Key Macroeconomic Assumptions Underlying Baseline } \\
\hline Real GDP growth (in percent) & 7.9 & 6.3 & 7.3 & -7.1 & -1.3 & 1.5 & 3.7 & 3.8 & 4.3 & 4.0 & 4.1 & \\
\hline GDP deflator in Euros (change in percent) & 13.8 & 19.8 & 4.4 & -9.4 & 5.1 & 5.8 & 4.9 & 5.8 & 5.6 & 5.9 & 5.7 & \\
\hline Nominal external interest rate (in percent) & 3.8 & 3.7 & 3.6 & 2.9 & 2.4 & 3.0 & 2.8 & 2.7 & 2.6 & 2.4 & 2.3 & \\
\hline Growth of exports (Euro terms, in percent) & 19.3 & 15.9 & 16.6 & -14.9 & 20.7 & 16.9 & 9.1 & 9.5 & 9.1 & 9.4 & 9.4 & \\
\hline Growth of imports (Euro terms, in percent) & 25.2 & 24.7 & 13.2 & -28.9 & 16.3 & 12.8 & 9.3 & 8.8 & 9.5 & 9.5 & 9.0 & \\
\hline Current account balance, excluding interest payments & -9.2 & -12.2 & -10.1 & -2.4 & -2.7 & -2.4 & -2.7 & -2.9 & -3.1 & -3.2 & -3.4 & \\
\hline Net non-debt creating capital inflows & 8.6 & 5.8 & 6.1 & 3.4 & 2.8 & 5.9 & 3.4 & 3.9 & 3.7 & 1.7 & 1.7 & \\
\hline
\end{tabular}

$\mathrm{e}=$ nominal appreciation (increase in dollar value of domestic currency), and $\mathrm{a}=$ share of domestic-currency denominated debt in total external debt.

$1 /$ Derived as $[r-g-\rho(1+g)+\varepsilon \alpha(1+r)] /(1+g+\rho+g \rho)$ times previous period debt stock, with $r=$ nominal effective interest rate on external debt; $\rho=$ change in domestic GDP deflator in uro terms, $g=$ real GDP growth rate,

$\varepsilon=$ nominal appreciation (increase in dollar value of domestic currency), and $\alpha=$ share of domestic-currency denominated debt in total external debt.

2/ The contribution from price and exchange rate changes is defined as $[-\rho(1+g)+\varepsilon \alpha(1+r)](1+g+\rho+g \rho)$ times previous period debt stock. $\rho$ increases with an appreciating domestic currency $(\varepsilon>0)$ and rising inflation $(b a s e d ~ o n ~ G D P ~ d e f l a t o r)$.

$3 /$ For projection, line includes the impact of price and exchange rate changes.

$4 /$ Defined as current account deficit, plus amortization on medium- and long-term debt, plus short-term debt at end of previous period.

5/ The key variables include real GDP growth; nominal interest rate; dollar deflator growth; and both non-interest current account and non-debt inflows in percent of GDP.

$6 /$ Long-run, constant balance that stabilizes the debt ratio assuming that key variables (real GDP growth, nominal interest rate, dollar deflator growth, and non-debt inflows in percent of GDP) remain at their levels

of the last projection year. 


\section{ROMANIA: LETTER OF INTENT}

Bucharest, September 14, 2011

Mme. Christine Lagarde

The Managing Director

International Monetary Fund

Washington, DC, 20431

U.S.A.

Dear Mme. Lagarde:

1. The economic program supported by the International Monetary Fund (IMF), the European Union (EU), and the World Bank (WB) is generating concrete results in helping to boost potential growth and maintain fiscal and financial stability. The economy has stabilized and growth is now resuming, fueled by strong exports. We continue to expect growth of $1 \frac{1}{2}$ percent in 2011 , rising to $3 \frac{1}{2}-4$ percent in 2012, although downside risks exist due to uncertainties in the international environment and challenges in absorbing EU investment funds. A favorable harvest will help growth in 2011 and is moderating the inflationary pressures that were evident earlier in the year due to high global food and energy prices. Nevertheless, achievement of the NBR's end-2011 inflation target remains unlikely, particularly as additional increases in administered prices will be needed. The current account deficit is expected to remain below 5 percent of GDP in 2011-12 on the back of improved trade performance. Continued firm policy implementation is required to safeguard against risks, as the recovery remains vulnerable to adverse developments in international financial markets and to downside risks to euro area recovery.

2. Our performance on the quantitative targets and the structural reform agenda for the second review has been strong (Tables 1 and 2).

- $\quad$ Quantitative performance criteria and indicative targets. All end-June 2011 quantitative performance criteria were observed. All indicative targets were also met except the ceiling on arrears of key loss-making SOEs. The floor on general government balance was met with a significant margin of 0.4 percent of GDP. Inflation marginally breached the inner band of the inflation consultation mechanism and we have consulted with Fund staff as required under the program.

- $\quad$ Structural benchmarks. We made significant progress on SOE reforms. We have already appointed legal advisors for Oltchim, Transelectrica, Transgaz, and Romgaz. For most of the central government SOEs, action plans are completed and we are designing mechanisms to facilitate restructuring SOE arrears. We aim to fulfill the remaining components of the structural benchmark by the time of the Board meeting. 
3. In view of our strong performance under the macroeconomic program supported by the Stand-By Arrangement (SBA), the Government of Romania and the National Bank of Romania (NBR) request completion of the second review under the SBA. We intend to continue to treat the arrangement as precautionary.

4. We believe that the policies set forth in the letters of March 10, 2011, June 9, 2011 and in this Letter are adequate to achieve the objectives of our economic program, but we stand ready to take additional measures as appropriate to ensure achievement of its objectives. As is standard under all IMF arrangements, we will consult with the IMF before modifying measures contained in this Letter or adopting new measures that would deviate from the goals of the program, and will provide the IMF and the European Commission (EC) with the necessary information for program monitoring.

\section{Fiscal Policy}

5. For 2011, we are on track to meet the cash fiscal deficit target of 4.4 percent of GDP (or within 5 percent in ESA terms). Revenues (net of EU funds) were slightly above expectations in the second quarter, while both current and capital expenditures were below the program, allowing us to meet the performance criterion with a comfortable margin. For the remainder of the year, we will continue implementing policies outlined in the previous Letters of March and June 2011. We maintain tight control of current spending, and have reduced public employment more quickly than originally anticipated (by another 18,000 positions in the second quarter of 2011). Hence, we are well on track to meet our commitment to keeping the wage bill below 7.5 percent of GDP in 2011. By end-August, we will eliminate central government heating subsidies, while improving the legislation to provide heating allowances to target the vulnerable members of society and generating budget savings. Local governments would also be required to fully budget and fund their heating subsidies. As previously agreed, we will also allocate additional funds to the health house in the second semester to cover unpaid bills, including those revealed in the stocktaking exercise undertaken for the last review, thus avoiding the accumulation of new arrears. These allocations will be tied to concrete progress on the healthcare reform program ( $\mid 13)$. We will also continue efforts to improve and prioritize capital spending in order to increase the absorption of EU funds. By end-September, we will complete a comprehensive review of the existing investment portfolio and produce a report and an action plan to prioritize and assess the projects (structural benchmark).

6. In order to bring closer the cash and ESA measures of the fiscal balance, we will start monitoring selected SOEs ${ }^{1}$ on a monthly basis; once this system is fully functional, we will

\footnotetext{
${ }^{1}$ The expanded definition of the general government will include the following SOEs: Compania Nationala a Huilei S.A., Compania Naționala de Autostrăzi si Drumari Naționale, Fondul Proprietatea, Metrorex S.A., Regia Autonoma Administrația Fluviala a Dunării de Jos Galați, Societatea Naționala a Cărbunelui S.A.,
} 
request that the performance criterion on the general government overall balance be amended to include the operating balance of these entities. We will also continue to improve the reporting system for the state-owned enterprises (SOEs) that are to be added to the ESA definition of the general government and with the technical assistance of Eurostat, enhance our ability to measure the fiscal deficit on an accrual basis.

7. For 2012, we are committed to bringing the ESA and cash deficits within 3 percent of GDP. We will set the 2012 cash budgetary envelope consistent with this objective and will identify additional measures to reach it. ${ }^{2}$ Achieving this target will require sustained expenditure restraint. Reforms already undertaken in the pension system and in consolidating and means-testing social benefits programs are expected to generate savings. Assiduous implementation of health sector reforms and restructuring of public enterprises included in the general government will also be crucial to achieve the 2012 targets. In order to complete the restoration of the temporary 25 percent public wage cut passed in 2010 , we will implement further wage increases during the course of 2012. However, these increases will be conditional on further progress in reducing public employment by attrition so as to maintain the total wage bill at or below 7.2 percent of GDP. We continue to be fully committed to responsible public wage policies which ensure fiscal sustainability and help preserve competitiveness.

8. We remain committed to continued responsible fiscal policy in the medium-term, consistent with our fiscal strategy and Fiscal Responsibility Law. We will strictly limit further ad hoc changes to the tax system to ensure predictability and stability. With the technical assistance of the IMF, we will review the tax system by the end of the year to close tax loopholes and improve its efficiency. Should the economic recovery create sufficient fiscal space, we will consider a gradual reduction in social contributions. We will continue to support the independent Fiscal Council, by providing it with adequate information and funding.

9. Arrears and unpaid bills of the general government (excluding SOEs) have been declining since the beginning of the year. Arrears now stand below 0.2 percent of GDP (almost entirely in the local governments). In SOEs monitored under the program, arrears have stabilized in the second quarter of 2011 at 3.6 percent of GDP. However, the conclusion of the stocktaking exercise for other central government SOEs revealed additional arrears (of around 0.4 percent of GDP), while we continue to collect data for local government SOEs. With the assistance of Fund and EC staff, we have developed an action plan to deal with arrears, with the following key elements:

Societatea Naționala de Transport Feroviar de Calatori, Compania Naționala de Radiocomunicații Navale Radio Constanţa, Compania Naţionala de Căi Ferate CFR S.A., and Termoelectrica S.A.

2 The final cash deficit necessary to achieve an ESA deficit will be agreed during the October review, pending findings from the ongoing Eurostat review. 
- In the health sector, we remain committed to repaying arrears in full by end-2011 and prevent new arrears arising. However, additional budget allocations to the sector will be strictly conditioned on progress on reforms of the system, to forestall the accumulation of new arrears.

- $\quad$ At the local level, the new amendments to the local government public finance law are acting as a deterrent to new arrears accumulation. We will explore the possibility of extending its provisions to try to limit arrears accumulation in local government SOEs as well.

- $\quad$ Over the next two years the period for paying bills submitted to the central government and social security system will be gradually reduced. The EU directive 7 in this area will be transposed into Romanian law on a timely basis.

- $\quad$ For $\boldsymbol{S O E S}$, we are making progress on designing mechanisms to significantly reduce arrears in SOEs monitored under the program: (i) nonviable firms will be moved into bankruptcy, allowing the legal procedures to handle creditor claims; (ii) firms with sufficient positive cash flow will be required to pay down arrears on an agreed schedule; (iii) the government has developed budget neutral arrangements to cancel or forgive arrears to the state itself, (iv) in appropriate cases we are seeking approval from EU competition authorities of plans to increase capital and/or provide direct financial support to pay arrears; (v) we are developing mechanisms to facilitate restructuring and securitizing SOE arrears; and (vi) where possible, debt-equity swaps or privatization proceeds will be used to cancel arrears. Firms' participation in these schemes will be strictly conditioned on their successful execution of agreed action plans to assure that arrears do not re-accumulate. We anticipate that these measures will permit SOE arrears to be reduced by at least RON 4 billion ( 0.8 percent of GDP) by end-2011, with additional reductions expected in 2012 .

- $\quad$ The next phase in the integration of the accounting reporting system with the Treasury payment system, the design of the system, including the commitment control and reporting module for all levels of government will be completed by endDecember 2011. This system will help control spending commitments to avoid accumulating future arrears.

- $\quad$ To prevent possible arrears in future due to unfunded contracts, we will ensure that any commitments made at the central government level for multiannual capital projects are appropriately reflected in the fiscal accounts and new guarantees issued for bank financing of these projects are transparently recorded within the program guarantee ceiling of RON 14 billion.

10. We have improved our financing strategy and will continue to focus on extending the maturity of our domestic debt, building the yield curve, and consolidating the financial buffers. We launched our euro medium-term notes program with a June issue for $€ 1.5$ billion 
and plan to continue regular external bond issuance 1-2 times per year in both euro and dollars at a range of maturities. We remain committed to consolidating our financial buffer to around four months of financing needs during 2011-12 to protect government finances against unforeseen external shocks. To enhance our capabilities, in 2011 we are conducting a formal review of our debt management strategy with the assistance of IMF, EC, and WB experts by end-2011. We will also further improve treasury information technology (IT) systems and strengthen senior staffing.

11. Improving tax administration and fighting tax evasion are crucial elements of our strategy to increase revenue. We are making progress on implementing the recently approved ordinance relating to high net wealth individuals, and the government decision on indirect audit methods; however, additional efforts are needed. Among the key developments are the following:

- We prepared an organizational strategy and implementation plan for incorporating indirect audit methods into our compliance functions, with a view to starting auditing individuals in 2012. We will also expand the tax audit coverage of the largest taxpayers.

- We passed the government decision on ANAF restructuring and have closed 141 regional offices by end-July. This will allow us to reduce collection costs and staff the Tax Verification Directorate.

- We will also develop and implement a compliance risk strategy in accordance with best practices by end-September 2011. As a first step, we have already established a department in charge of risk assessment in ANAF.

- $\quad$ With help from the IMF and EC, we will introduce simplified taxation for smaller taxpayers in key economic sectors under the threshold. We have already requested an increase in the VAT mandatory threshold from the EU Council of Ministers to $€ 50,000$ (structural benchmark, end-December 2011). We will also review VAT refund processes for exporters to significantly streamline the timeframe for issuance.

- We are planning expansion of e-filing and further simplification of tax forms and the number of payments required with a view to providing a one-stop shop for tax declaration and payments. We will continue our efforts to modernize work processes, introduce IT systems and consolidate organization structures of ANAF to fundamentally improve tax administration.

- Having incorporated the stimulente into the base wage for most institutions, we have prepared the government ordinance to eliminate the legal basis of all stimulente funds effective January 1, 2012 and will pass it by end-August (structural benchmark). For remaining institutions, the process of incorporating the stimulente will be completed by end-December 2011, via the wage law applicable to budget staff in 2012. 
12. Improving the absorption of EU funds remains a difficult challenge, and further efforts are needed. We have prepared a priority action plan in the areas of project management, financing, public procurement, administrative capacity, audit and control, and have started producing quarterly reports on the implementation of these priorities. We are committed to implementing the actions defined in this plan within the set deadlines. The government has moved the EU structural funds coordination unit from the MOPF to the Prime Minister's office and will strengthen its authority. We have created facilities for reallocating the budget resources during the year to those ministries with the best EU funds absorption performance and a track record of efficient project implementation. We will improve the efficiency of public procurement process by developing standard bidding documents in key subsectors by end-November to reduce the grounds for contesting public tenders and will revise the PPP law to ensure that it fully conforms to EU procurement directives. To avoid problems discovered in deficient reimbursement claims to the EU, we have temporarily suspended the submission of new claims until additional vetting can take place. We hope to have an improved submission process in place by end-September.

13. We are focusing on prioritizing investment to assure sufficient financing for key projects. We are conducting a comprehensive review of the existing investment portfolio and have prepared a database of the stock of all government projects. This database will be used to prioritize and evaluate projects to focus on those where funding can be fully secured within a medium-term horizon (e.g., 3-5 years), to discontinue low priority and non-performing projects that cannot be fully financed within this horizon, and to produce a final report and an action plan by end-September 2011 (structural benchmark).

14. In the health sector, while we have undertaken some important restructuring measures aimed at removing inefficiencies in the hospital system, such as reduction of inpatient admissions and beds through closure of small hospitals, they have not been sufficient to stabilize the rising costs in the health sector. Arrears have been nearly eliminated, but additional unpaid bills from 2010 of some RON 500 million were uncovered in the stocktaking exercise and adequate mechanisms need to be applied to ensure future spending remains within allocations. We will ensure that no new arrears will accumulate in the sector, first by allocating RON 300 million in the mid-year supplementary budget to pay down unpaid bills, with additional resources to be made available before the end of the year. However, additional allocations will be strictly conditioned on progress on restructuring. In 2012, we will ensure that budget allocations are consistent with a realistic spending program, while incorporating savings from reforms. Over the medium-term, given that public healthcare spending in Romania is among the lowest in the EU as a share of GDP, we will ensure adequate financing in line with the recommendation of the 2008 Presidential Commission on health care policy while factoring in the challenge of population aging into spending needs.

15. To address the persistent budgetary shortfalls in the healthcare system and to ensure a more high quality health care system, we will undertake a fundamental reform of the system. 
To contain the growth of spending, we will encourage cost-containment through budget caps and seek to reduce the scope of the public benefits package through greater reliance on costsharing and private insurance. We will prepare, by end-2011 (structural benchmark), comprehensive amendments to the health care legislation based on these principles, with the aim of approving it by end-March 2012. The legislation would include modifications such as the following:

- $\quad$ Global spending measures. We will specify a revised package of benefits insured by the government to exclude coverage of costly nonessential health services, to be implemented next year, with the technical assistance of the World Bank financed projects. The services exceeding the basic scope would be provided via supplementary insurance, including private insurance.

- $\quad$ Pharmaceutical expenditures. (i) We will revise settlement prices and the list of compensated and free drugs and move to generics, where possible, on the $\mathrm{C} 2$ list by end-October 2011.

- $\quad$ Revenue enhancements. We will significantly step up income measures with the goal of containing excess demand and reducing the structural deficit in the system. (i) The previous mechanisms for a clawback tax for pharmaceuticals did not achieve the expected outcome. We will impose a revised clawback tax on the pharmaceuticals based on the growth in their costs or above a pre-determined threshold (structural benchmark). (ii) We will introduce copayments for medical services, by end-2011.

- $\quad$ Progress continues on implementing new healthcare IT systems. The auditing of patient registries is underway and will be completed by end-2011. At the beginning of 2012, we will begin rolling out new health cards for all participants, which will help control fraud and abuse in the system and better monitor spending commitments. We will also begin to apply strict drug use protocols and a new electronic prescription module for the National Health Information System, following strict procedures. We will also internalize the National Health Accounts System and will initiate the development of the Health Technology Assessment System by end-2011. These mechanisms will help ensure that future spending remains within allocations.

16. Improving the efficiency of social protection remains a priority, including in the area of social inspection. Our efforts have yielded significant results, as the number of beneficiaries of heating allowances has declined by approximately 54 percent in the 2010-11 season versus 2009-10 due to new eligibility criteria. A new Social Assistance Law has been drafted, which will consolidate the existing categories of social benefits into 9 and tighten eligibility criteria. The Law should be adopted by Parliament by end-September and come into effect in January 2012. This will be followed by significant changes in secondary legislation. The overall measures on social benefit reforms will result in fiscal savings of around 0.8 percent of GDP in 2010-13. 


\section{Financial Sector}

17. The banking system remains well capitalized, with an average solvency ratio of 14.2 percent at end-June. The rise in non-performing loans slowed over the last quarter, reaching 13.4 percent of total loans at end-June compared to 12.7 percent at end-March. Bank lending to the corporate sector picked up in the second quarter, but real growth remained negative on an annual basis which—along with further provisions - continued to weigh upon bank profitability.

18. The passage of amendments (by ordinance) to the Deposit Guarantee Fund (DGF) law is on track to be completed by end-September 2011 (reset benchmark). The amendments will allow for the use of resources administered by the DGF (including through guarantees) to facilitate restructuring measures authorized by the National Bank of Romania regarding the transfer of deposits, including purchase and assumptions, if such use would be less costly than the direct payment of deposit guarantees. We have reviewed the DGF, banking and winding-up legislation and will make amendments by end-October to ensure their mutual consistency and to introduce bridge bank powers into the legislation. In this context the bridge bank would be a new, temporary, full-service bank authorized and supervised by NBR with the aim to facilitate, its sale, in whole or in part, to eligible private acquirers as soon as practicable. Parliament is now expected to ratify earlier amendments to the winding-up legislation by end-September. In conjunction with the DGF, we will continue to develop and strengthen our procedures and contingency planning for deploying these new restructuring powers as a priority. The range of collateral eligible for NBR lending operations has been expanded to include leu-denominated IFI issued bonds and foreign currency-denominated sovereign bonds.

19. We remain committed to the introduction of IFRS accounting standards in the banking system beginning in 2012. To allow the banks sufficient time to implement changes we will by end-September 2011 finalize the prudential and fiscal treatment of regulatory filters to preserve prudent bank solvency, provisions, and reserves. Net amounts arising from the release of provisions due to the new accounting treatment and which are treated accordingly as retained earnings from specific provisions to support regulatory capital will not be taxed. The NBR will also introduce by end-October 2011 regulatory measures to ensure that foreign currency credit to households is appropriately priced in order to reflect the risk represented by lending in foreign currency to unhedged borrowers. We will continue to consult with the IMF and EC staff before introducing or amending other aspects of the regulatory framework and make efforts to avoid adopting legislative initiatives which could undermine debtor discipline.

\section{Monetary and Exchange Rate Policy}

20. Despite a sharp drop in annual inflation in June and July, the NBR's 2011 inflation target is unlikely to be met due to the surge in international food and energy prices earlier in the year, as well as the envisaged adjustment of administered prices in the remainder of the 
year. ${ }^{3}$ The inner inflation consultation band with the Fund was marginally exceeded at endJune (Table 1), and may continue to be triggered later in the year based on current projections. We now expect inflation to continue to decline from its peak of 8.4 percent in May, falling to around 5 percent by the end of 2011. Nevertheless, we are vigilant against risks that persistently high headline inflation could result in inflationary expectations becoming more entrenched. The increase in core inflation over the past year, (net of the VAT effect) also suggests potential risk of pass-through from large supply shocks. To forestall such pressures, we will maintain our tightening bias in monetary policy stance and take action as needed to ensure 2012 inflation target is met. In particular, we will continue to improve our liquidity management so as to bring money market rates closer to the policy rate. At the same time, the NBR will remain alert to the potential risks of capital flows due to volatility in international financial markets.

\section{Structural Reforms}

\section{State-Owned Enterprises}

21. We are progressing with our ambitions reform agenda for state-owned firms. In line with the restructuring plans discussed during the last review, measures have been implemented for 18 key SOEs, contributing to achieving the second quarter indicative target on the operating balance of these companies by a wide margin. However, the indicative target for arrears was missed. We have also enhanced our monitoring of central government SOEs by extending our database and will develop a similar database for local SOEs.

22. Restructuring of central government SOEs is progressing. We have finalized action plans for many of the 154 companies specified in the last LOI and most of the measures identified at the last review have been implemented. We will finalize this process for these firms in the coming weeks. For remaining central government SOEs currently in our database, we will develop plans by end-December.

23. Progress is also being achieved in the privatization process. While the recent offer of an additional 9.8 percent stake in Petrom was unsuccessful, we remain committed to the agreed calendar for privatizing minority stakes in other firms, and we will reoffer the Petrom shares in a market-friendly process in early 2012. Shares in other public firms will be offered in three groups beginning with Transelectrica in October and Transgaz in December. ${ }^{4}$ For the

\footnotetext{
${ }^{3}$ The elimination of the central government heating subsidy is expected to add about a half percentage point to the CPI in late 2011, and increases in electricity and transport tariffs will also boost inflation.

${ }^{4}$ The first group comprises: i) Oltchim (sale of remaining public shares to strategic investor); ii) Romgaz (IPO of 15 percent stake); iii) Tarom (strategic investment or IPO of 20 percent); iv) Transelectrica (SPO of 15 percent stake plus a later capital increase of about 12 percent ); (v) Transgaz (SPO of 15 percent stake).
}

The second group contains: i) Termoelectrica (complete sale of Galati subsidiary and Braila branch and continuing the process of creating joint ventures with strategic investors in ELCEN in order to build new power 
first group, we have already appointed legal advisors for all firms except Tarom, which we expect to complete by end-October. Also by end-October, we will appoint the transaction advisor for the first group and the legal advisor for the second (structural benchmark). We will consult closely with IMF and EC staff in this process. In addition to the privatizations, we continue preparations to resolve the financial situation of Termoelectrica. By end-2011, we intend either to use ANAF collection procedures to take over the company's assets or place it into bankruptcy proceeding. In either case, we will extract and sell viable assets quickly.

24. To improve the governance of SOEs, we will develop and approve governance legislation by end-October 2011 (structural benchmark reset from end-August). This legislation will require all SOEs to have regular independent external audits, to report and publish financial data quarterly, to reinforce minority shareholder rights, and to move financial control of SOEs from line ministries to the MOPF. It will include an application code for all SOEs to ensure that OECD principles on corporate governance are applied. For the largest firms slated to remain under majority state control (as identified in the TMU), the legislation will specify that all key management positions (including the CEO and CFO) will be filled only after an open international search process conducted by internationally recognized human resources firms. These managers will also be given sufficient autonomy to operate the firms free from undue interference. Board members of these firms will be selected by the shareholders and vetted by independent experts (unconnected with existing firms or the government) to assure that they are fully qualified to exercise their functions. Existing managers and board members could submit their applications and their professional qualifications would be considered. This management search will begin by end-October and private management teams will be selected by end-December to take office as soon as legally possible thereafter. In cases where significant minority stakes are to be sold, this timetable may be adjusted to allow for participation of the new minority shareholders. To make this effective, this may require changing Emergency Ordinance 3/2011 only for the new private managers. Based on the experience of this exercise, and depending on the performance of current management, we are firmly committed to increasing the number of SOEs with private management in the course of 2012.

25. In the transport sector, we continue to implement measures to cut expenditures and raise revenues in public firms, in line with the measures specified in our letter of

units, majority private owned, in Bucharest and Constantza); ii) Hidroelectrica (IPO of 10 percent to increase capital); and (iii) Petrom (SPO of 9.84 percent stake will be re-launched);

The third group includes: (i) Electrica Serv (majority privatization of the entire company); ii) Nuclearelectrica (at least 10 percent via capital increase); iii) the new company created by merging the 3 remaining Electrica supply subsidiaries (registered in the Trade Register as S.C. Electrica Furnizare S.A.) and the supply activity of Electrica (majority privatization); iv) the 3 remaining Electrica distribution subsidiaries (majority privatization), in accordance with the decisions of the National Council of Defense. 
June 9, 2011. For the rail sector we are nearly finished implementing standard costs for infrastructure procurement and maintenance of rolling stock. In order to bring the rail sector closer to economic viability, we will continue the process of closing 1000 line kilometers. In addition, we will tender out the remaining 1600 line kilometers agreed and, in case the tendering fails, close them. Personnel cuts have been approved and are to a large extent already implemented. In order to increase revenues, we have prepared the legal basis for tariff adjustments for metropolitan transit and passenger rail, and we will implement those in the coming months. Similarly, the single road authority for freight transport is being created and measures are underway to further enhance toll collection.

26. For the energy sector we envisage major reforms. Our strategy to form two national champion energy companies remains blocked by court rulings, and we are beginning to implement an alternative strategy, including the partial privatizations of a number of energy firms as specified above. Accordingly, we will recommend to the relevant authority to officially modify its decision on setting-up these two champions. To address pricing and regulatory framework issues within the energy sector, we will undertake the following steps: (i) To restore the energy regulator's (ANRE) operational and financial autonomy in accordance with EU legislation (third energy package), by mid-September we will produce draft legislation that has been consulted with and consistent with comments received from the European Commission; (ii) we will increase the price to better align with CUG for non-residential customers by 8 percent(prior action), while leaving the price for residential consumers unchanged; (iii) present a roadmap for phasing out regulated prices in electricity and gas by end-December 2011; (iv) define the vulnerable consumers by end-2011 according to EU legislation and develop mechanisms to protect them (in conjunction with the Ministries of Finance and Labor); (v) complete removal, according to EU directives, of regulated prices for non-households in electricity and gas before end 2013 and complete the process by end-2015; (vi) assure that new bilateral contracts are made transparently and nondiscriminately through OPCOM (electricity) and other competitive procedures (gas); and that their prices will be adjusted to prevailing market rates as quickly as legally permissible; ${ }^{5}$ and (vii) approve legislation which would require publication of all new bilateral contracts of state-owned gas and electricity generators and that the terms in existing contracts are not extended.

\section{Labor Markets and Judicial Reform}

27. We have made substantial reforms in the labor legislation. The new Labor Code, which has entered into force on April $30^{\text {th }}$, has improved labor market flexibility by promoting fixed-term and temporary employment, extending probation periods, and increasing the flexibility of working hours. A substantial number of new contracts $(600,000)$ have been registered since April. The Social Dialogue Code modifying collective bargaining

\footnotetext{
${ }^{5}$ If EU infringement procedures require faster action, we will comply with their requirements.
} 
and other labor relations has recently been promulgated and we are currently developing regulations for their implementation, to be prepared by end-August. Key elements of the social dialogue reform include raising representativity thresholds, abolishing the collective bargaining at national level, and elimination of the automatic erga-omnes extension at sectoral level. We are committed to ensuring that the new legislation observes EU directives and core ILO and EU conventions and will consult with ILO later this year.

28. Measures to reform the judiciary are underway, with a view to make it more effective, unifying the jurisprudence, and fighting against corruption, which will provide for a transparent business environment and boost the economic performance. One of the top ranking objectives of the Government related to the reform of the judiciary is the successful implementation of the new fundamental legal codes for Romania: the civil code, the criminal code, the civil procedure code and the criminal procedure code. The measures to be taken to implement these codes will be decided upon after the finalization of the impact studies currently in progress. We will also undertake reforms in the agricultural sector-including by speeding up the surveying and registration of agricultural land - to improve food security and increase export prospects.

\section{Program modifications and monitoring}

29. The program will continue to be monitored through regular reviews, prior actions, quantitative performance criteria and indicative targets, and structural benchmarks. The quantitative targets for end-September 2011 and end-December 2011 and continuous performance criteria are set out in Table 1; where the changes in the end-September performance criterion on Net Foreign Assets and the adjustor to the general government balance have also been made (and in the TMU); and prior actions and structural benchmarks are set out in Table 2. The understandings between the Romanian authorities and IMF staff regarding the quantitative performance criteria and the structural measures described in this letter are further specified in the attached Technical Memorandum of Understanding.

$/ \mathrm{s}$

Gheorghe Ialomiţianu Minister of Public Finance
$/ \mathrm{s}$

Mugur Isarescu

Governor of the National Bank of Romania

Attachments 
Table 1. Romania: Quantitative Program Targets

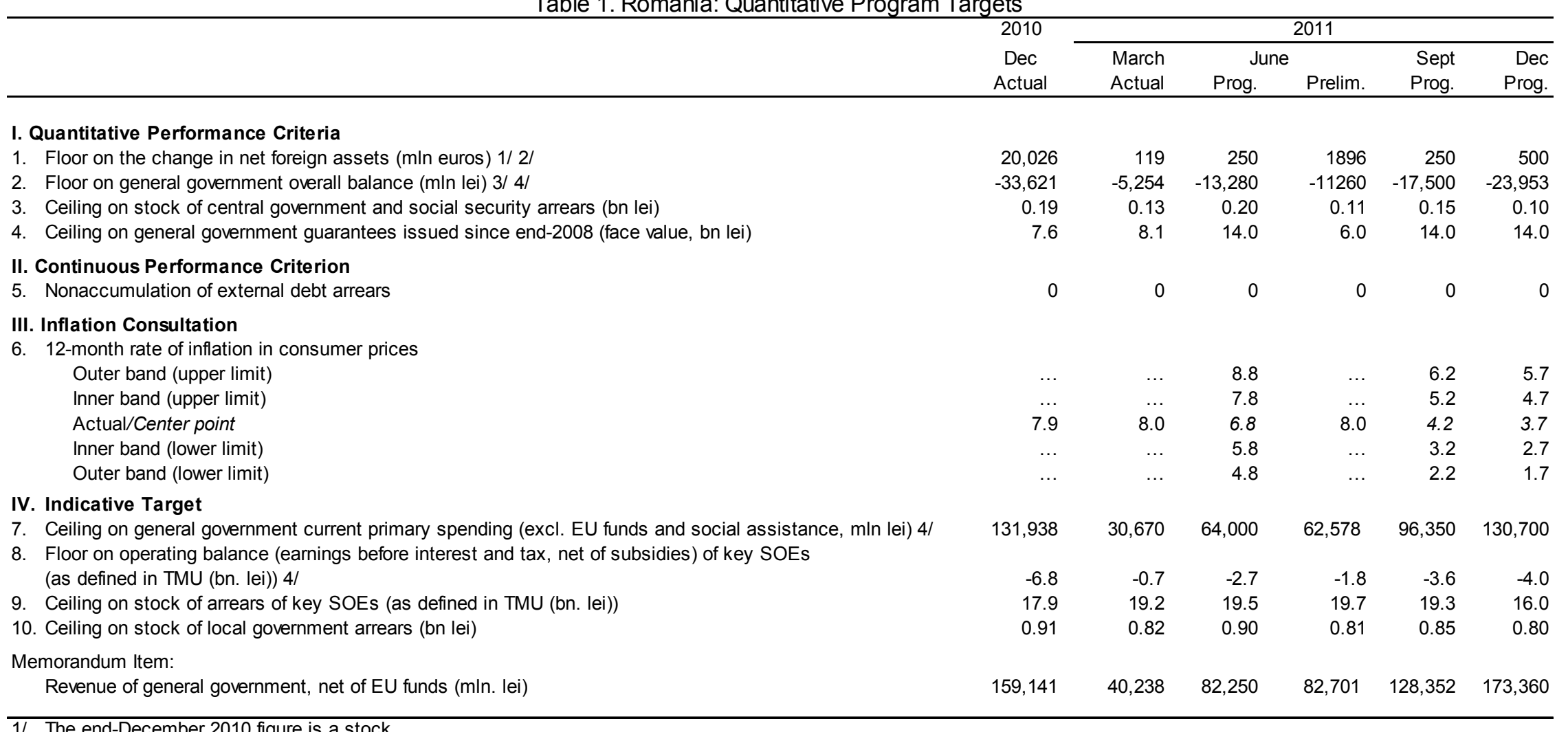

2010 figure is a stock.

2/ Cumulative flows relative to end-December 2010 stock.

3/ Cumulative figure during calendar year (e.g. March 2011 figure is cumulative from January 1, 2011)

4/ Adjusted performance criterion for end-June. 
Table 2. Romania: Performance for Second Review and Proposed New Conditionality

Measure $\quad$ Comment Date

Prior Actions

1. Increase the gas price for non-residential customers, in order to further align with CUG formula, by 8 percent.

At least 5 working days before the

Quantitative performance criteria

1. Floor on net foreign assets

2. Floor on general government overall balance

3. Ceiling on central government and social security domestic arrears

4. Ceiling on general government guarantees

5. Non-accumulation of external debt arrears

\section{Quantitative Indicative Target}

1. Ceiling on general government current primary spending

2. Floor on operating balance of key SOEs

3. Ceiling on stock of arrears of key SOEs

4. Ceiling on stock of local government arrears

\section{Inflation consultation band}

Inner band

Outer band

\section{Structural benchmarks}

1. Undertake SOE reforms, including (i) Appointment of legal advisors for privatization of CFR Marfa, TAROM, Transelectrica, Transgaz, and Romgaz; (ii) Preparation of action plans for the remaining SOEs of the central government; (iii) Design mechanisms to facilitate restructuring and securitizing SOE arrears.

2. Approve legislation to improve governance of SOEs.

3. Eliminate by government ordinance the legal basis of all the stimulente funds, effective January 1, 2012.

4. Completion of a comprehensive review of the existing investment portfolio, which will prioritize and evaluate existing projects to focus on those where funding can be fully secured, examine the viability of old projects, with low Sept. 30, 2011 priority and unviable ones discontinued, and production of a final report and an action plan.

5. Amend legislation to allow the use of the deposit guarantee fund resources to facilitate bank restructuring, including purchase and assumption transactions.

6. Introduction of a simplified taxation system for smaller taxpayers under the threshold with help from the IMF and EC, while requesting a shift in the VAT mandatory threshold from the EU Council of Ministers to $€ 50,000$.

Nov. 30, 2011

New structural benchmark

1. Selection of advisors for SOE reform: (i) select transaction advisors for group 1 and (ii) legal advisors for group 2

2. Impose a revised clawback tax on the pharmaceuticals based on the growth in their costs or above a predetermined threshold.

3. Prepare comprehensive amendments to the health care legislation to address the persistent budgetary shortfalls and to ensure high quality health care services. 


\title{
ROMANIA: TECHNICAL MEMORANDUM OF UNDERSTANDING (TMU)
}

\author{
September 14, 2011
}

1. This Technical Memorandum of Understanding (TMU) defines the variables included in the quantitative performance criteria and indicative targets set out in the letter of intent (LOI), the key assumptions, the methods to be applied in assessing program performance, and the reporting requirements to ensure adequate monitoring of economic and financial developments. The quantitative performance criteria and indicative targets, and structural benchmarks for 2011 are listed in Tables 1 and 2 of the LOI, respectively.

2. For the purposes of the program, the exchange rates of the Romanian Leu (RON) to the euro is set at RON $4.2848=€ 1$, to the U.S. dollar at RON 3.2045 $=\$ 1$, to the Japanese yen at RON $3.9400=¥ 100$, and to the pound sterling at RON $4.9673=£ 1$, the rates as shown on the National Bank of Romania's (NBR's) website as of December 31, 2010. The exchange rates to other currencies, where applicable, will also be the ones shown on the NBR's website as of December 31, 2010.

3. For the purposes of the program, the general government includes the entities as defined in the 2011 budget. These are: the central government (state budget, treasury, self-financed state entities included in the budget, etc.), local governments, social security funds (pension, health, and unemployment), road fund company, and administration of the property fund. This definition of general government also includes any new funds, or other special budgetary and extra budgetary programs that may be created during the program period to carry out operations of a fiscal nature as defined in the IMF's Manual on Government Finance Statistics 2001. The authorities will inform IMF staff of the creation of any such new funds or programs immediately. As mentioned in the LOI ( $\uparrow 5)$ and $\uparrow 11$ below, this definition will be expanded to cover state-owned enterprises incorporated into the general government accounts under ESA95, upon completion of the review being undertaken by Eurostat.

\section{Quantitative Performance Criteria, Indicative Targets, Inflation Consultation Band, and Continuous Performance Criteria}

\section{A. Floor on the Change in Net Foreign Assets}

4. For program purposes, Net Foreign Assets (NFA) are defined as the NFA of the NBR minus Treasury liabilities to the International Monetary Fund.

5. NFA of the NBR are defined as the euro value of gross foreign assets of the NBR (including reserve requirements of the commercial banking system held at the NBR) minus gross foreign liabilities of the NBR; and will be measured on the basis of the NBR's operational rather than accounting definitions. Non-euro denominated foreign assets and liabilities will be converted into euro at the program exchange rates. 
6. Gross foreign assets of the NBR are defined to include the NBR's holdings of SDRs, the country's reserve position at the IMF, holdings of cash, securities and deposits abroad in convertible foreign currencies. Excluded from reserve assets are: (i) gold and other precious metals; (ii) assets in nonconvertible currencies; (iii) illiquid assets; (iv) any assets that are pledged, collateralized, or otherwise encumbered, unless there is also a gross foreign liability associated with it; (v) claims on residents; and (vi) claims in foreign exchange arising from derivatives in foreign currencies vis-à-vis domestic currency (such as futures, forwards, swaps, and options).

7. Gross foreign liabilities of the NBR are defined as all foreign exchange liabilities to residents and nonresidents, including commitments to sell foreign exchange arising from derivatives (such as futures, forwards, swaps, and options), and all credit outstanding from the IMF, but excluding (i) banks' foreign currency deposits against reserve requirements; and (ii) government foreign currency deposits at the NBR. This definition is meant to bring the concept of foreign liabilities closer to the balance of payment definition, on which the targets are based.

Floor on cumulative change in NFA from the beginning of the year (in mln. euros) ${ }^{1}$

\begin{tabular}{|c|c|c|c|c|c|}
\hline & \multirow{2}{*}{$\begin{array}{c}2010 \\
\text { December } \\
\text { (stock) }\end{array}$} & \multicolumn{4}{|c|}{2011} \\
\hline & & $\begin{array}{l}\text { March } \\
\text { (actual) }\end{array}$ & $\begin{array}{c}\text { June } \\
\text { (actual) }\end{array}$ & $\begin{array}{c}\text { September } \\
\text { (PC) }\end{array}$ & $\begin{array}{c}\text { December } \\
(\mathrm{PC})\end{array}$ \\
\hline $\begin{array}{c}\text { Cumulative change in } \\
\text { NFA }\end{array}$ & 20,026 & $119^{2}$ & 1,896 & 250 & 500 \\
\hline $\begin{array}{l}\text { Memorandum Item: } \\
\text { Gross Foreign Assets }\end{array}$ & 32,432 & 996 & 2,793 & 1000 & 1000 \\
\hline
\end{tabular}

8. NFA targets will be adjusted upward (downward) by the surplus (shortfall) in program disbursements relative to the baseline projection. Program disbursements are defined as external disbursements from official creditors (World Bank and the EC) that are usable for the financing of the overall central government budget. The NFA targets will also be adjusted upward by the increase in commercial bank reserve requirements held with the NBR relative to end-December 2010 ( $€ 6,797$ million), measured at program exchange rates. 
External program disbursements-Baseline projections (in mln. euros)

\begin{tabular}{ccccc}
\hline & \multicolumn{4}{c}{2011} \\
\cline { 2 - 5 } & March & June & September & December \\
\hline $\begin{array}{c}\text { Cumulative flows from end } \\
\text { of previous year }\end{array}$ & 1,200 & 1,650 & 2,050 & 2,050 \\
\hline
\end{tabular}

\section{B. Consultation Mechanism on the 12-month Rate of Inflation}

9. The quarterly consultation bands for the 12-month rate of inflation in consumer prices (as measured by the headline consumer price index (CPI) published by the Romanian Statistical Institute), are specified below. Should the observed year-on-year rate of CPI inflation fall outside the outer bands specified below, the authorities will complete a consultation with the IMF on their proposed policy response before requesting further purchases under the program. In addition, the NBR will conduct discussions with IMF staff should the observed year-on-year rate of CPI inflation fall outside the inner bands specified for the end of each quarter in the table below.

\begin{tabular}{llllcc}
\hline & 2010 & \multicolumn{3}{c}{2011} \\
\cline { 3 - 6 } & $\begin{array}{l}\text { December } \\
\text { (actual) }\end{array}$ & $\begin{array}{l}\text { March } \\
\text { (actual) }\end{array}$ & $\begin{array}{l}\text { June } \\
\text { (actual) }\end{array}$ & $\begin{array}{l}\text { September } \\
\text { (target) }\end{array}$ & $\begin{array}{l}\text { December } \\
\text { (target) }\end{array}$ \\
\hline Outer band (upper limit) & & & & 6.2 & 5.7 \\
Inner band (upper limit) & & & & 5.2 & 4.7 \\
Actual / Center point & \multirow{2}{*}{8.9} & \multirow{2}{*}{8.0} & \multirow{2}{*}{8.0} & 4.2 & 3.7 \\
Inner band (lower limit) & & & & 3.2 & 2.7 \\
Outer band (lower limit) & & & & 2.2 & 1.7 \\
\hline
\end{tabular}

\section{Performance Criterion on General Government Balance}

10. The budget deficit will be monitored quarterly through the cash balance of the general government. The authorities will consult with IMF staff on corrective measures in the event of shortfalls in government revenue and financing. 


\begin{tabular}{lc}
\hline & (In millions of lei) \\
\hline & $-33,621$ \\
End-December 2010 (actual) & $-5,254$ \\
End-March 2011 (actual) & $-11,260$ \\
End-June 2011 (actual) & $-17,500$ \\
End-September 2011 (performance criterion) & $-23,953$ \\
End-December 2011 (performance criterion) & \\
\hline Cumulative figure during calendar year (e.g., March 2011 figure is cumulative from \\
January 1, 2011). \\
$\quad$ The budget deficit will be measured from above the line using the budget execution \\
11. \\
data. Once the reporting system for state-owned enterprises (SOEs) is fully functional, the \\
budget deficit target will be modified to be in line with the expanded definition of the \\
general government which will include the following SOEs ${ }^{1}$ : Compania Nationala a Huilei \\
S.A., Compania Nationala de Atostrazi si Drumari Nationale, Fondul Proprietatea, Metrorex \\
S.A., Regia Autonoma Administratia Fluviala a Dunarii de Jos Galati, Societatea Nationala \\
a Carbunelui S.A., Societatea Nationala de Transport Feroviar de Calatori, Compania \\
Nationala de Radiocomunicatii Navale Radio Constanta, Compania Nationala de Căi Ferate \\
CFR S.A., Termoelectrica S.A.
\end{tabular}

12. The Ministry of Public Finance (MOPF) will also provide monthly data to measure the deficit from below the line. The balance of the general government measured from below the line will include:

+ (i) net external financing, excluding valuation gains and losses;

+ (ii) change in net domestic credit from the financial system, excluding valuation gains and losses from deposits denominated in foreign currency and including adjustments for;

+ (a) received EU funds not yet spent (advance payments);

+ (b) claims of the government on EU funds;

+ (c) property fund obligations not yet paid;

+ (iii) change in the stock of issued government securities, net of valuation changes;

+ (iv) net changes in other financing.

13. If the difference between the general government deficit measured from above the line and from below the line is larger than lei 200 million each quarter during 2011, the MOPF will consult with IMF staff.

\footnotetext{
${ }^{1}$ The list of SOEs to be included in the definition of general government will be determined by Eurostat in the upcoming months, including possible revisions to those SOEs already incorporated.
} 
14. In the event that non-grant revenues (including those received in arrears reduction plans) exceed those projected under the program, the performance criterion for the general government balance will be adjusted upward by one half of the surplus to allow for additional capital spending while reducing the deficit further. The following table shows the accumulated projected non-grant revenue for 2011, to which the actual non-grant revenue will be compared.

\begin{tabular}{lr} 
Cumulative projected revenue of general government, net of EU funds ${ }^{\mathbf{1}}$ & (In millions of lei) \\
\hline & \\
End-December 2010 (actual) & 159,141 \\
End-March 2011 (actual) & 40,238 \\
End-June 2011 (actual) & 82,701 \\
End-September 2011 (projection) & 128,352 \\
End-December 2011 (projection) & 173,360 \\
\hline${ }^{1}$ Cumulative figure during calendar year (e.g., March 2011 figure is cumulative from January 1, 2011).
\end{tabular}

15. The performance criterion for the general government balance for endSeptember 2011 (measured on a cumulative basis from the beginning of the year) will be adjusted downward by the amount that capital spending (including spending related to EU funds and arrears reduction plans) exceeds 25,944 million lei up to a limit of 1,400 million lei.

\section{Performance Criterion Limiting the Issuance of Government Guarantees to the Non-Financial Private Sector and Public Enterprises}

16. The issuance of general government guarantees to the non-financial private sector and public enterprises will be limited during the program period. This ceiling is set at RON 14 billion but may be adjusted upward by up to RON 9.6 billion for guarantees for financing the Nabucco project. Revision to targets will be renegotiated during future missions to allow for reasonable public guarantees in the context of privatization of majority stakes in stateowned enterprises and securitization of domestic payment arrears.

\begin{tabular}{lc}
$\begin{array}{l}\text { Ceiling on new general government guarantees issued from end- } \\
\text { 2008 until: }\end{array}$ & (In billions of lei) \\
\hline & 7.6 \\
End-December 2010 (actual) & 8.1 \\
End-March 2011 (actual) & 6.0 \\
End-June 2011 (actual) & 14 \\
End-September 2011 (performance criterion) & 14 \\
End-December 2011 (performance criterion) & \\
\hline
\end{tabular}




\section{E. Performance Criterion on the Stock of Domestic Arrears by the Central Government and Social Security System}

17. The performance criterion established on the stock in domestic payments arrears of the central government and social security sector (as defined in $\{3$ above) contemplates their elimination during the program period. The stock will be measured net of intergovernmental arrears, but both gross and net arrears will be reported by the government. In case of need, the government will take corrective measures to prevent the accumulation of new spending arrears. For the purpose of the program, arrears mean accounts payable past due date by 90 days (in line with ESA95 definitions for expenditures).

\begin{tabular}{lc}
\hline Stock of central government and social security arrears & (In billions of lei) \\
\hline & \\
End-December 2010 (actual) & 0.19 \\
End-March 2011 (actual) & 0.15 \\
End-June 2011 (preliminary) & 0.11 \\
End-September 2011 (performance criterion) & 0.15 \\
End-December 2011 (performance criterion) & 0.10 \\
\hline
\end{tabular}

\section{F. Continuous Performance Criteria on Non-Accumulation of External Payments Arrears by the General Government}

18. The general government will not accumulate external payment arrears during the program period. For the purposes of this performance criterion, an external payment arrear will be defined as a payment by the general government which has not been made within seven days of falling due. The performance criterion will apply on a continuous basis.

\section{G. Indicative Target on General Government Current Primary Spending}

19. The indicative target on current primary expenditure of the general government is defined as spending on personnel, goods and services excluding EU funds (specified under external grant category), subsidies, transfers to public entities, pensions (social security budget in social assistance category), state aid and other spending in other transfers category, Reserve Fund, and other expenditure as classified in the monthly reporting tables. Actual data (to which the target will be compared) should include payments related to arrears reduction plans.

\begin{tabular}{lc}
$\begin{array}{l}\text { Cumulative change in general government current primary } \\
\text { expenditures }\end{array}$ & (In millions of lei) \\
\hline End-December 2010 (actual) & 131,938 \\
End-March 2011 (actual) & 30,670 \\
End-June 2011 (actual) & 62,578 \\
End-September 2011 (indicative) & 96,350 \\
End-December 2011 (indicative) & 130,700 \\
\hline${ }^{1}$ Cumulative figure during calendar year (e.g., March 2011 figure is cumulative from \\
January 1, 2011).
\end{tabular}




\section{H. Indicative Target on Local Government Arrears}

20. The indicative target on the stock of domestic payments arrears of local governments contemplates no accumulation of new arrears and their reduction during the program period. In case of need, the government will take corrective measures to prevent the accumulation of new spending arrears. For the purpose of the program, arrears mean accounts payable past the due date by 90 days (in line with ESA95 definitions for expenditures).

\begin{tabular}{lc}
\hline Stock in local government arrears & (In billions of lei) \\
\hline & \\
End-December 2010 (actual) & 0.91 \\
End-March 2011 (actual) & 0.82 \\
End-June 2011 (actual) & 0.81 \\
End-September 2011 (indicative) & 0.85 \\
End-December 2011 (indicative) & 0.80 \\
\hline
\end{tabular}

\section{Monitoring of Public Enterprises}

21. Public enterprises are defined as all companies, research institutes and regii autonome with a cumulative public capital share of 50 percent or more, held directly or indirectly by local governments and the central government.

22. A quarterly indicative target for 2011 is set on the aggregate operating balance (earnings before interest and tax) net of subsidies, accumulated per calendar year, of the following public enterprises: C.N. Căi Ferate CFR S.A., C.N. de Autostrãzi de Drumuri Nationale din România S.A., C.N. a Huilei S.A., C.N. Poşta Românã S.A., S.C. Complexul Energetic Turceni S.A., S.C. Filiala de Intretinere si Servicii Energetice "Electrica Serv" S.A., S.C. Metrorex S.A., S.N. de Transport Feroviar de Marfă "CFR Marfă” S.A., S.N. Transport Feroviar de Călători "CFR Călători" S.A., C.N. Tarom S.A., S.C. Electrocentrale Bucuresti S.A., S.C. Electrica Furnizare Transilvania Nord S.A., S.C. Oltchim S.A., S.C. Termoelectrica S.A., SNa Lignitului Oltenia S.A., S.C. Electrificare CFR S.A., S. C. Interventii Feroviare S.A., S. C. Telecomunicații C.F.R. S.A. The data shall be reported with operating results by firm. The targets will be as follows:

\begin{tabular}{lc}
\hline Floor on cumulative operating balance & \\
\hline End-December 2010 (actual) & (In billions of lei) \\
End-March 2011 (preliminary) & -6.6 \\
End-June 2011 (preliminary) & -0.7 \\
End-September 2011 (indicative) & -1.8 \\
End-December 2011 (indicative) & -3.6 \\
\hline
\end{tabular}

${ }^{1}$ Cumulative figure during calendar year (e.g., March 2011 figure is cumulative from January 1, 2011). 
In case one of these firms is liquidated, or its majority share is privatized or merged with a company not listed above, the aggregate target listed above will be adjusted by the original operating balance target for this firm.

23. A quarterly indicative target for 2011 is set on the stock of arrears of the public enterprises listed in $\mid 22$. The data shall be reported at the firm level. The targets will be as follows:

Ceiling on stock of arrears

End-December 2010 (actual)

End-March 2011 (preliminary)

End-June 2011 (preliminary)

End-September 2011 (indicative)

End-December 2011 (indicative)
(In billions of lei)

17.9

19.2

19.7

19.3

16.0

In case one of these firms is liquidated, its majority share is privatized or is merged with a company not listed above, the aggregate target listed above will be adjusted by the original arrears target for this firm.

\section{J. Private Management for Key SOEs}

24. Private management will be selected, in line with LOI 923 , at least for the following state-owned enterprises: i) C.N. Poşta Românã S.A., ii) C.N. Tarom S.A., iii) S.N. de Transport Feroviar de Marfă "CFR Marfă" S.A., iv) S.C. Electrificare CFR S.A., v) SNa Lignitului Oltenia S.A., vi) S.C. Electrica Furnizare S.A., vii) SC Hidroelectrica, viii) CN Romarm aparat central, ix) S.C. Oltchim S.A. In addition, private management is envisaged in the course of 2012 for the following additional companies: i) C.N. Căi Ferate CFR S.A., ii) S.N. Transport Feroviar de Călători "CFR Călători” S.A., iii) SN Nuclearelectrica, iv) S.N. Transgaz, v) CN Transelectrica, and vi) SN Romgaz. 


\section{K. Reporting Requirements}

25. Performance under the program will be monitored from data supplied to the IMF by the NBR and the MOPF as outlined in the table below. The authorities will transmit promptly to IMF staff any data revisions as well as other information necessary to monitor the arrangement with the IMF.

Romania: Data Provision to the IMF

\begin{tabular}{|c|c|}
\hline Item & Periodicity \\
\hline
\end{tabular}

To be provided by the Ministry of Finance

Preliminary monthly data on general government accounts, including public enterprises as defined by ESA95

Quarterly final data on general government accounts, including public enterprises as defined by ESA95

The budget deficit of the general government using ESA95 definition

Preliminary data on below-the-line financing for the general government

Final quarterly data on below-the-line financing for the general government

Total accounts payable and arrears of the general government, including local governments

Stock of the central government external arrears

Public debt and new guarantees issued by the general government

Preliminary monthly data on general government primary spending, net of EU disbursements

Final quarterly data on general government primary spending, net of EU disbursements

Preliminary data on the operating balance, profits, stock of arrears, and personnel expenditures for each key public enterprise as defined in $\uparrow 22$

Final data on the operating balance, profits, stock of arrears, and personnel expenditures for each key public enterprise as defined in $\uparrow 22$
Monthly, on the $25^{\text {th }}$ day of the following month

Quarterly cash data, on the $35^{\text {th }}$ day past the test date; Quarterly accrual data, on the $55^{\text {th }}$ day past test date

Quarterly, with a lag of three months

Monthly, with a lag of no more than 35 days past the test date

Quarterly, no later than 45 days past the test date

Preliminary monthly, within the next month.

Quarterly, within 55 days

Daily, with a lag of not more than seven days

Monthly, within one month

Preliminary monthly data will be reported to IMF staff within 25 days

Quarterly, within 35 days from the test date

Quarterly, within 30 days

Quarterly, end May for the previous year and endAugust for first half of the current year 
Data on EU project grants (reimbursements and advances), capital expenditures and subsidies covered by EU advances or eligible for EU reimbursement on EU supported projects specifically agreed with the EU

The balance of the TSA in RON

The balance of the two foreign currency accounts used for budget financing and public debt redemption purposes (average, and end-of-period)

The balance of the privatization receipts registered in the account of the State Treasury, details on any claims on these receipts and projected net outflows.

\section{To be provided by the National Bank of Romania}

NFA data, by components, in both program and actual exchange rates

Monetary survey data in the format agreed with IMF staff

The schedule of contractual external payments of the banking sector falling due in the next four quarters, interest and amortization (for medium and long-term loans)

The schedule of contractual external payments of the corporate sector falling due in the next four quarters interest and amortization (for medium and long-term loans)

The stock of short-term external debt of banks and corporate

Balance of payments in the IMF format currently used to report

Exposure (deposits, loans, subordinated loans) of (i) foreign parent banks to their subsidiaries in Romania; (ii) IFI and (iii) other creditors to banks in Romania (by national and foreign currency).
Monthly, within three weeks of the end of each month

Monthly, within two weeks of the end of each month

Monthly, within two weeks of the end of each month

Monthly, within two weeks of the end of each month

Weekly, each Monday succeeding the reporting week and with a 3 working day lag in the case of endquarter data

Monthly, within 30 days of the end of the month

Monthly, 45 days after the end of each month

Monthly, 45 days after the end of each month

Monthly, 45 days after the end of each month

Monthly, 45 days after the end of each month

Monthly, 20 days after the end of each month 


\section{ANNEX \\ Measures to Improve Performance of SOEs under Monitoring}

\section{C.N. de Autostrãzi de Drumuri Nationale din România S.A.}

- $\quad$ Create a single road control authority by end-September 2011

- Increase revenues by extending information system for the toll system by end-2011

- $\quad$ Reduce costs by applying standard costs both for existing contracts, through a renegotiation process, and for new contracts

\section{S.N. de Transport Feroviar de Marfă "CFR Marfă" S.A.}

- $\quad$ Approve remaining standard costs for maintaining rolling stock by end-August 2011, to be required on all new contracts

- $\quad$ Amend the budget of the company by end-September 2011 as the originally included capital increase is not included in the government's budget revision.

- $\quad$ Contract consultancy services for the study regarding the principle of the cautious private investor and the criteria for awarding the restructuring aid in the event of the recapitalization of the society by end-October 2011

- Integrate all subsidiaries by end-October 2011, including Societatea Comercială de Transport Maritim şi de Coastă "C.F.R. Ferry-Boat"-S.A., except Societatea Comercială Întreţinere şi Reparaţii Locomotive şi Utilaje "C.F.R. IRLU”-S.A

- $\quad$ Merger of the maintaintenace companies of Marfa and Calatori (Societatea Comercială Întreţinere şi Reparaţii Locomotive şi Utilaje "C.F.R. IRLU”-S.A and Societatea comerciala de reparaţii locomotive C.F.R. SCRL Braşov S.A.), to be directly owned by Ministry of Transport and Infrastructure, by end-December 2011

- $\quad$ Appoint private management and board members by end-December 2011 or byJanuary 2012 if a significant minority share will have been sold by end-2011

- Continuous reinforcement of efforts to collect outstanding invoices, including by giving notice to contracts and taking legal measures against companies with substantial arrears

\section{S.N. Transport Feroviar de Călători "CFR Călători" S.A.}

- $\quad$ Approve remaining standard costs for maintaining rolling stock by end-August 2011, to be required on all new contracts

- $\quad$ Adjust tariffs beyond inflation by mid-September 2011

- Use payment to be received from the government for social train tariffs (about $0.2 \mathrm{bn}$. lei) for arrears reduction by end-September 2011.

- $\quad$ Integrate 3 (of 4) subsidiaries by end-November 2011

- $\quad$ Merger of the maintaintenace companies of Marfa and Calatori (Societatea Comercială Întreţinere şi Reparaţii Locomotive şi Utilaje "C.F.R. IRLU”-S.A and Societatea comerciala de reparaţii locomotive C.F.R. SCRL Braşov S.A.), to be directly owned by Ministry of Transport and Infrastructure, by end-December 2011 
- $\quad$ Differentiate tariffs by train category (IC, IR and R) by end-December 2011

- $\quad$ Appoint private management and board members in the course of 2012, if experience with private management in SOEs is positive

- $\quad$ Reduce the operating costs and increase the attractiveness of the railway transport by start replacing the old rolling stock with diesel railcars and electric multiple units based on a long term program

\section{C.N. Căi Ferate CFR S.A.}

- $\quad$ Subordinate the GEI Palaţ and Telecomunicatii subsidiaries to the Ministry of Transport and Infrastructure by end-September 2011

- Integrate all subsidiaries except Electrificare, GEI Palaţ, S.C. Informatică Feroviară S.A., Telecomunicatii and Tipografia into the mother company by end-October 2011

- $\quad$ Publish tenders for public service obligations and infrastructure maintenance for 1600 line kilometers of extended railway by end-October 2011 , bringing the total number of line kilometers under private management to 4000 kilometers

- $\quad$ Conclude the closing of 1000 kilometers of railway lines, originally foreseen for endAugust, by end-2011Use expected government's capital increase and strictly conditioned on reform measures a credit to reduce arrears to the general government budget and the electricity suppliers by end-December 2011

- $\quad$ Close all extended railway lines for which tenders failed by end-April 2012

- $\quad$ Continue insolvency procedure for the Tipografia subsidiary; if liquidation can be avoided, the process to full privatization of the company will be started immediately

- $\quad$ Appoint private management and board members in the course of 2012, if experience with private management in SOEs is positive

\section{S. C. Interventii Feroviare S.A.}

- Integration into mother company by end-September 2011

\section{S.C. Electrificare CFR S.A.}

- $\quad$ Reduce personnel to 2775 positions by end-August 2011

- $\quad$ Appoint private management and board members by end-December 2011

\section{S. C. Telecomunicatii C.F.R. S.A.}

- $\quad$ Reduce personnel by at least 100 positions (compared with end-2010) by endAugust 2011

- $\quad$ Complete steps for turning SC Telecomunicatii S.A. into a company under the authority of Ministry of Transports and Infrastructure

- $\quad$ Elaborate legislation establishing the new framework for supplying telecommunication services within an integrated system 


\section{S.C. Metrorex S.A.}

- $\quad$ Adjust tariffs beyond inflation by end-August 2011

- $\quad$ Passage of legislation to establish a new metropolitan transport authority by endAugust 2011

- $\quad$ Reduce maintenance costs by 30 percent by end-2011

- Undertake the necessary steps for including Metrorex into the list of potential beneficiaries of the Sectoral Operational Programme - Transport for the use of EU structural funds

\section{C.N. Tarom S.A.}

- $\quad$ Elaborate the TAROM 2012-2016 Development Plan (signing the consulting services contract with IATA Consulting until end-August 2011)

- $\quad$ Appoint the investment bank / SSIF (Financial Investments Services Company) which will also provide the legal advice for privatization of at least a 20 percent stake via IPO or strategic investor by end-October 2011

- $\quad$ Publish prospectus by mid-December 2011

- $\quad$ Conclude privatization by end-2011

- $\quad$ Appoint private management and board members by end-January 2012

- Reduce costs such as renegotiation of contracts, voluntary personnel reductions, discontinuation of selected lines and flights, etc. and increase revenues such as alternative sales strategies and optimizing pricing policies)

- $\quad$ Reduce costs by extending the saving oil consumption program

\section{C.N. Poşta Românã S.A.}

- Continuous reinforcement of efforts to collect outstanding invoices

- $\quad$ Appoint private management and board members by end-December 2011

- $\quad$ Reduce postal subunits from 7100 at end-2010 to around 5800 until endDecember 2011

\section{S.C. Oltchim S.A.}

- $\quad$ Appoint private management and board members by end-December 2011

- $\quad$ Appoint investment bank for full privatization by end-October 2011, publish prospectus for SPO by end November 2011 and conclude privatization by end-2011

\section{S.C. Termoelectrica S.A.}

- $\quad$ Appoint legal advisor and transaction advisor for sale of viable assets (including joint ventures) or start forced execution by ANAF by end-October 2011 
- $\quad$ Continue dismantling of production capacity of at least 150MW (compared with end2010) by end-October 2011

- Continuous reinforcement of efforts for collecting outstanding invoices,

- Complete sale of viable assets by end-2011 including Electrocentrale Galati and the current branch in Braila

- $\quad$ File for liquidation of remaining parts of Termoelectrica by end-2011

\section{S.C. Electrocentrale Bucuresti S.A.}

- $\quad$ Elimination of all arrears to Romgaz by end-September 2011

- Use payments from government under district heating related arrears reduction schemes (about $0.1 \mathrm{bn}$. lei) for arrears reduction by end-September 2011

- $\quad$ Continue process of creating joint ventures with strategic investors to built new power units in Bucharest and Constanta with private majority share

\section{S.C. Filiala de Intretinere si Servicii Energetice "Electrica Serv" - S.A.}

- $\quad$ Split company into regional companies and prepare for privatization of all companies by end-December 2011

- $\quad$ Appoint legal advisor for majority privatization of regional companies via IPO or to strategic investor by end-2011

- $\quad$ Appoint transaction advisor for privatization by end-March 2012

- $\quad$ Conclude privatization by end-June 2012 and file for liquidation for all subsidiaries for which privatization failed by end-September 2012

- $\quad$ Continue assessment of possibilities to sell or lease out assets

\section{S.C. Electrica Furnizare Transilvania Nord S.A.}

- $\quad$ Finalize merger of 3 Electrica supply subsidiaries to S.C. Electrica Furnizare S.A. by end-December 2011

- $\quad$ Appoint private management and board members for S.C. Electrica Furnizare S.A. by end-December 2011

- $\quad$ Appoint legal advisor for majority privatization of S.C. Electrica Furnizare S.A. via IPO or to strategic investor by end-2011

- $\quad$ Appoint transaction advisor by end-March 2012

- $\quad$ Conclude privatization by end-June 2012

\section{S.C. Complexul Energetic Turceni S.A.}

- $\quad$ Reduce personnel by 200 (compared with end-2010) by end-September 2011

- $\quad$ Create new energy producer by merging SNLO and the three energy complexes in Craiova, Rovinari and Turceni by end-December 2011

- $\quad$ Appoint legal advisor for majority privatization of newly created company via IPO or to strategic investor by end-2011 
- $\quad$ Appoint transaction advisor by end-March 2012

- $\quad$ Conclude privatization by end-June 2012

\section{C.N. a Huilei S.A}

- $\quad$ Submit pre-notification of restructuring plan including envisaged split of assets and liabilities into viable and non-viable parts to DG Comp by mid-August 2011

- $\quad$ Submit formal notification including valuation of assets and liabilities by end-September 2011

- $\quad$ Reduce personnel by at least 900 positions (compared with end-2010) by end-October 2011

- $\quad$ Start forced execution by ANAF to take over viable parts of CNH for tax liabilities as soon as legal acts have been approved

- $\quad$ Approve necessary legal acts for split, one month after the approval by DG Comp

- $\quad$ Merge viable assets into a new energy producer, together with power plants in Paroşeni and Mintia

- $\quad$ Appoint legal advisor for majority privatization of new energy producer by end-December 2011

- Appoint transaction advisor for majority privatization of new energy producer by end-March 2012

- $\quad$ Complete majority privatization of new energy producer by end-June 2012

\section{SNa Lignitului Oltenia S.A.}

- Use government payments under district heating and heavy water related arrears reduction schemes (about 0.4 bn. lei) for arrears reduction by end-September 2011

- $\quad$ Continue negotiation with customers, including SOEs, to pay arrears to SNLO

- $\quad$ Create new energy producer by merging SNLO and the three energy complexes in Craiova, Rovinari and Turceni by end-December 2011 (see above under S.C. Complexul Energetic Turceni S.A.)

- $\quad$ Appoint private management and board members for new company by end-December 2011 


\title{
INTERNATIONAL MONETARY FUND
}

\author{
ROMANIA \\ Second Review Under the Stand-By Arrangement, \\ and Request for Modification of Performance Criteria- \\ Supplementary Information \\ Prepared by the European Department \\ (In Consultation with Other Departments) \\ Approved by Anne-Marie Gulde and Aasim Husain
}

September 23, 2011

1. This supplement provides an update on economic and policy developments since the issuance of the staff report on September 14, 2011. The additional information does not change the thrust of the staff appraisal.

2. Recent indicators suggest a slowdown in export growth, in line with regional trends, while domestic demand appears to be turning around. GDP growth slowed to 0.2 percent in the second quarter (qoq) with a large negative contribution of net exports. Domestic demand improved as consumption growth turned positive, reflecting the favorable agricultural harvest and public sector wage increases. High frequency indicators show that these trends will likely continue. Net real wages increased by 3.5 percent, domestic trade indicators improved and private credit growth continued to recover. Headline inflation in August declined further to 4.3 percent on the back of a strong decline in food prices, which offset increases in railway tariffs (of 10 percent m-o-m) and other administered prices. For 2012, market analysts have been revising down growth by 0.5 to $1 \mathrm{pp}$ in light of the revised EU projections, and staff expects to revise downward by a similar magnitude during the upcoming mission.

3. Financial market stress has worsened, reflecting global developments as well as spillovers from difficulties elsewhere in Europe. CDS spreads rose by an additional 50 basis points since the beginning of September, broadly in line with regional peers, but are still below the highs reached during the Greek crisis in mid-July last year. Average yields for government paper have been rising, resulting in lower than planned issuance during August and thus far in September.

4. The authorities are stepping up efforts to improve EU funds absorption. A new Ministry for Coordinating European Funds Absorption has been set up.

5. The government has met the prior action. On September 22, the government announced its decision to raise CUG gas prices for non-residential customers by 8 percent. The structural benchmark for amending the legislation on the use of Deposit Guarantee Funds to facilitate bank restructuring was also met. 


Prior Actions
1. Increase the gas price for non-residential customers, in order to furth
Quantitative performance criteria
1. Floor on net foreign assets
2. Floor on general government overall balance
3. Ceiling on central government and social security domestic arrears
4. Ceiling on general government guarantees
5. Non-accumulation of external debt arrears

Target Date

Comment

\section{Quantitative Indicative Target}

1. Ceiling on general government current primary spending

2. Floor on operating balance of key SOEs

3. Ceiling on stock of arrears of key SOEs

4. Ceiling on stock of local government arrears

\section{Inflation consultation band}

Inner band

Outer band

At least 5 working

days before the

Board meeting

June 30, 2011

June 30, 2011

June 30, 2011

June 30, 2011

June 30, 2011

Met

Met

Met

Met

Met

Met

\section{chmarks}

1. Undertake SOE reforms, including (i) Appointment of legal advisors for privatization of CFR Marfa, TAROM, Transelectrica, Transgaz, and Romgaz; (ii) Preparation of action plans for the remaining SOEs of the central government; (iii) Design mechanisms to facilitate restructuring and securitizing SOE arrears.

2. Approve legislation to improve governance of SOEs.

3. Eliminate by government ordinance the legal basis of all the stimulente funds, effective January 1, 2012.

4. Completion of a comprehensive review of the existing investment portfolio, which will prioritize and evaluate existing projects to focus on those where funding can be fully secured, examine the viability of old projects, with low priority and unviable ones discontinued, and production of a final report and an action plan.

5. Amend legislation to allow the use of the deposit guarantee fund resources to facilitate bank restructuring, including purchase and assumption transactions.

6. Introduction of a simplified taxation system for smaller taxpayers under the threshold with help from the IMF and EC, while requesting a shift in the VAT mandatory threshold from the EU Council of Ministers to $€ 50,000$

New structural benchmark

1. Selection of advisors for SOE reform: (i) select transaction advisors for group 1 and (ii) legal advisors for group 2

2. Impose a revised clawback tax on the pharmaceuticals based on the growth in their costs or above a pre-determined threshold.

3. Prepare comprehensive amendments to the health care legislation to address the persistent budgetary shortfalls and to ensure high quality health care services.

June 30, 2011

June 30, 2011

June 30, 2011

June 30, 2011

June 30, 2011

June 30, 2011

Met

Met

Not Met

Met

Not met

Met

July 15, 2011

Aug. 31, 2011

Aug. 31, 2011

Sept. 30, 2011

Nov. 30, 2011

Dec. 31, 2011

Oct. 31, 2011

Nov. 30, 2011

Dec. 31, 2011
Reset to Sept 30, 2011 (Met)

Partially met

Reset to Oct. 31, 2011

Met 
Press Release No. 11/351

International Monetary Fund

FOR IMMEDIATE RELEASE

Washington, D.C. 20431 USA

September 29, 2011

\section{IMF Completes Second Review Under Stand-By Arrangement with Romania}

The Executive Board of the International Monetary Fund (IMF) today completed the second review of Romania's economic performance under a program supported by a 24-month Stand-By Arrangement (SBA). The authorities have indicated that they will continue treating the arrangement as precautionary and therefore do not intend to draw under it.

The SBA was approved on March 25, 2011 (Press Release No 11/101) in the amount of SDR 3,090.6 million (about $€ 3,561$ million $^{1}$ or about US $\$ 4,854$ million). The SBA came into effect on March 31, 2011. Completion of the review makes an additional amount equivalent to SDR 430 million (about $€ 495$ million or about US\$675 million) available for disbursement, bringing the total resources that are currently available to Romania under the SBA to SDR 920 million (about $€ 1,060$ million or about US\$1,445 million)

Following the Executive Board's discussion on Romania, Mr. David Lipton, First Deputy Managing Director and Acting Chair, stated:

"Romania has made good progress under the new Stand-by arrangement. Policy implementation has remained strong and all performance criteria were met. The authorities' commitment to continued reform has helped restore market confidence and economic stability. Steadfast commitment to the economic reform agenda is crucial to safeguard these economic gains and better withstand shocks in an uncertain global environment.

"The authorities are on track to meet their fiscal targets for 2011. However, achieving the deficit target for 2012 remains challenging. More comprehensive action is needed to secure the financial sustainability of the health care sector. Faster progress is also needed to improve Romania's capacity to absorb EU funds. Deeper reform of state-owned enterprises-together with enhanced regulation and improved market-oriented pricing - will be essential to improve economic efficiency and boost growth.

1 All amounts exchange rates of September 28, 2011

Washington, D.C. 20431 • Telephone 202-623-7100 • Fax 202-623-6772 • www.imf.org 
"The banking system remains liquid and well-capitalized, but risks have risen due to difficulties elsewhere in Europe, and increased supervisory vigilance is warranted. Enhanced monitoring and detailed contingency plans - including procedures for using the newly enhanced bank resolution powers - are needed to guard against possible contagion. Monetary policy remains appropriately cautious in light of lingering inflation risks", Mr. Lipton said. 


\section{Statement by Mr. Age Bakker, Executive Director for Romania and Mr. Mihai Tanasescu, Senior Advisor to the Executive Director September 29, 2011}

The economic programs supported by the Fund, the European Union, and the World Bank played an important role in stabilizing the Romanian economy, generating concrete results in boosting growth and maintaining fiscal and financial stability. The current precautionary Stand-By Arrangement, approved in March 2011, aims at strengthening macroeconomic policies, accelerating structural reforms, and consolidating economic development.

Romania has continued its strong performance under the new program. All performance criteria for the second review were met, and all indicative targets, except the one on SOE arrears, have been met.

\section{Recent Economic Developments}

Economic growth has resumed, and Romania posted the third consecutive quarter of positive growth in the second quarter of 2011. Growth remained modest in the second quarter and slipped to 0.2 percent (q/q), but continued good performance of industrial output and a good harvest are expected to contribute to a rise of 1.5 percent for 2011 as a whole. GDP growth is expected to further accelerate in 2012 to around 3 percent, but downside risks have risen, due to uncertainties in the international environment and challenges in absorbing EU investment funds.

The inflation rate has dropped sharply in the last three months and reached 4.3 percent at end-August, from its peak of 8.4 percent in May, reflecting a large decline in food prices and the elimination of the first-round effect of the 2010 VAT increase from the 12-month index. We expect inflation to continue to decline, and the latest developments indicate that the NBR's 2011 inflation target is likely to be met.

The external position improved significantly. The current account deficit reached 4.1 percent of GDP in 2010, and is projected to stabilize at a similar level in 2011 and remain below 5 percent of GDP in 2012.

In July, Fitch upgraded Romania's long-term foreign currency rating to investment grade, and the leu appreciated somewhat by 3 percent against the euro. Due to the recent turbulence in international markets, these gains have been reversed and CDS spreads have risen apace with other economies in the region. On a positive note, international reserves remained comfortable at nearly 35 billion euro, covering more than 100 percent of the short-term debt at residual maturity.

Despite the progress achieved, the recovery remains vulnerable to adverse developments in international markets and weaker than expected growth in Western Europe. Spillovers from the ongoing turbulence in the euro area could further dampen exports and affect capital flows to Romania through the banking system. The authorities will remain vigilant, act proactively, and take the necessary steps to contain these risks. 


\section{Fiscal Policy}

The fiscal package implemented since the beginning of the previous program in 2009 has produced the targeted adjustment and put the fiscal stance on the right path. For 2011, the authorities are on track to meet the cash fiscal deficit target of 4.4 percent of GDP. For 2012, the authorities maintain their commitment to bring down the deficit to less than 3 percent of GDP. The preliminary budget preparation is based on a cash deficit of 2.8 percent of GDP. However, the current international environment, together with Eurostat's decision to add additional SOEs into the general government definition, could add another 0.3 percent of GDP to the deficit, which will make it challenging to reach the authorities' commitment to the European Commission of a fiscal deficit of 3 percent of GDP in accrual (ESA) terms. The Romanian authorities are fully committed to continue fiscal consolidation and to take the necessary steps, including continued expenditure restraint, to achieve their commitments.

On the expenditure side, the authorities will keep the wage bill within the agreed limit and take additional measures to secure the 2011 deficit target, including by continuing to rationalize public employment. The authorities will continue efforts to improve and prioritize capital spending in order to increase the absorption of EU funds. Efforts are underway to strengthen the administrative capacity of units managing European funds, and the recent decision to create the Ministry of European Affairs will accelerate this process. On health care reform, the authorities will implement a comprehensive package of measures to address the structural deficits of the healthcare system, which will include the introduction of copayments for medical service, creating a supplementary insurance contribution, and revising and simplifying the clawback tax on pharmaceuticals.

On the revenue side, tax policies will remain largely unchanged, including the VAT rate, which will be kept at 24 percent. With the technical assistance of the Fund, the authorities will review the tax code by the end of the year to close tax loopholes and improve its efficiency. Under the current program, improving tax administration and fighting tax evasion are crucial elements to increase revenue. The authorities already approved important measures, including a plan to promote the use of indirect audit methods in order to assess tax liabilities, and restructuring and closing 141 regional tax offices. Proposals to introduce a simplified tax regime for small taxpayers, to improve the VAT refund process, and to expand auditing of large taxpayers are underway.

To continue the fiscal consolidation path, the authorities are committed to decrease the stock of arrears. Arrears and unpaid bills of the general government have been declining since the beginning of the program. However, challenges remain in state-owned enterprises, where the arrears have stabilized in the second quarter of 2011. Additional efforts are needed to continue reducing them. In this context, the authorities have prepared a series of schemes to clear SOE arrears via netting arrangements, debt swaps, recapitalization of firms, arrears securitization, and government lending. 


\section{Monetary and Financial Sector Policies}

The monetary authorities responded appropriately to the contraction in economic activity, and the Central Bank has taken important measures to bring down inflation. Despite high inflation earlier in the year, the Central Bank did not see an immediate need for an increase in policy rates, but the authorities remain concerned about upside risks stemming from expected increases in administered prices. Recently, the inflation rate dropped sharply to 4.3 percent at end-August. As we expect inflation to continue to decline, the Central Bank's 2011 inflation target is likely to be met. In light of gathering risks of contagion from financial disturbances in the region and possible capital outflows, the authorities will remain vigilant against inflation risks and remains committed to take action as needed to assure achievement of its 2012 inflation target.

The Romanian financial system so far has weathered well the impact of the economic downturn of the past two years. The banking system remains well capitalized, with an average solvency ratio of 14.2 percent and a core tier 1 ratio of $13.6 \%$. The rise of nonperforming loans slowed over the last quarter, and bank lending to the corporate sector picked up, but real growth remained negative on an annual basis. A key role for keeping the financial sector in good health has been played by the European Bank Coordination Initiative which enabled the parent banks of the nine largest foreign-owned banks operating in Romania to keep their long-term capital exposure commitments to the country and consolidate capital levels. However, due to the recent international market turbulence, the level of exposure fell from 98 percent at end-March to 95 percent of the level when the initiative commenced. The Central Bank remains vigilant to weaknesses in the banking system and stands ready to provide liquidity as necessary to mitigate segmentation in the interbank market. It is also refining its full range of contingency measures to be deployed if necessary to preserve depositor confidence.

Progress continues to be made on the regulatory front, and the authorities are finalizing the regulatory framework and tax treatment for filters for provisioning that will preserve the current prudent approach once International Financial Reporting Standards are introduced for banks at the beginning of 2012. Significant progress has been made in finalizing the outstanding benchmark to enable the Deposit Guarantee Fund to finance the new bank resolution.

\section{Structural Reforms}

Under the current program the authorities are committed to deep-rooted reform of the stateowned enterprises (SOE), especially in the transport and energy sectors, to enable sustainable economic growth and better competitiveness. The authorities made progress in the reform agenda, and measures have been implemented for 18 key SOEs, contributing to achieving the second quarter indicative target on the operating balance of these companies. They have finalized action plans for many of the 154 companies, and implemented the necessary measures to improve their efficiency. Progress is also being achieved in the privatization process, and despite the recent unsuccessful offering of an additional 9.8 percent stake in Petrom, the authorities remain committed to the agreed calendar for privatizing minority 
stakes in other firms, and will reoffer the Petrom shares in a market-friendly process in early 2012. To improve governance of the SOEs, the authorities will develop and approve legislation requiring all SOEs to have regular independent external audits, to report and publish financial data quarterly, and to move financial control of SOEs from line ministries to the Ministry of Public Finance.

In the transport sector, the authorities continued to implement measures to cut expenditures and raise revenues. In the rail sector they implemented standard costs for infrastructure procurement and maintenance of rolling stock. In order to bring the rail sector closer to economic viability, the authorities will continue the process of closing 1000 kilometers of rail lines. Personnel cuts have been approved and are to a large extent already implemented. In order to increase revenues, the authorities prepared the legal basis for tariff adjustments for metropolitan transit and passenger rail and raised rates by 18 percent.

In the energy sector, the authorities will take the necessary steps to restore the energy regulator's operational and financial autonomy in accordance with EU legislation. The regulator will also continue to adjust prices for gas and electricity for non-residential consumers (on September 22, 2011 they increased gas prices by 8 percent), moving to world prices by end-2013. For households, adjustments will be more gradual, with the process completed by end-2015. The coal companies will continue to be downsized by forming separate legal entities and splitting viable and non-viable assets. The viable assets will later be privatized and non-viable assets will be liquidated in line with EU rules. For attracting more private investment, the authorities decided to pursue an alternative energy strategy with smaller energy companies, including the partial privatization of a number of them.

In conclusion, my authorities concur that the current precautionary Stand-By Arrangement will maintain the reform momentum, provide additional security against unforeseen shocks, and build on the considerable progress achieved over the past two years, thereby setting the stage for strong and sustainable economic development while maintaining external and internal stability. 